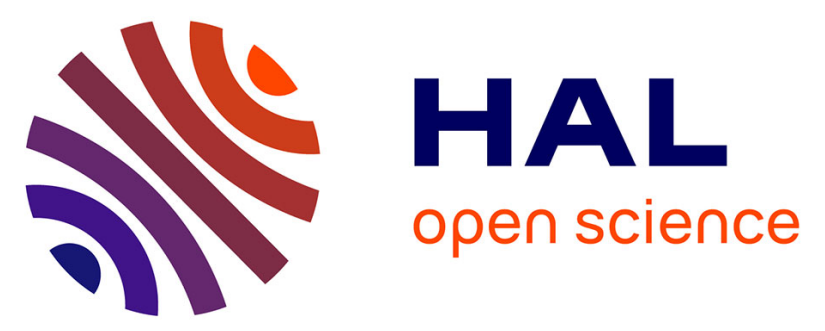

\title{
Lithium behaviour and isotope fractionation during fluid-rock interactions in Variscan oceanic suture zones: Limousin ophiolite and Ile de Groix high-pressure terrane (France)
}

Afifé El Korh, Etienne Deloule, Béatrice Luais, Marie-Christine Boiron, Luc Bastian, Nathalie Vigier

\section{To cite this version:}

Afifé El Korh, Etienne Deloule, Béatrice Luais, Marie-Christine Boiron, Luc Bastian, et al.. Lithium behaviour and isotope fractionation during fluid-rock interactions in Variscan oceanic suture zones: Limousin ophiolite and Ile de Groix high-pressure terrane (France). Journal of Petrology, 2019, 60 (10), pp.1963-1990. 10.1093/petrology/egz060 . hal-02410636

\section{HAL Id: hal-02410636 \\ https://hal.univ-lorraine.fr/hal-02410636}

Submitted on 10 Nov 2020

HAL is a multi-disciplinary open access archive for the deposit and dissemination of scientific research documents, whether they are published or not. The documents may come from teaching and research institutions in France or abroad, or from public or private research centers.
L'archive ouverte pluridisciplinaire HAL, est destinée au dépôt et à la diffusion de documents scientifiques de niveau recherche, publiés ou non, émanant des établissements d'enseignement et de recherche français ou étrangers, des laboratoires publics ou privés. 
Lithium behaviour and isotope fractionation during fluid-rock interactions in Variscan oceanic suture zones: Limousin ophiolite and Ile de Groix high-pressure terrane (France)

\author{
Afifé EI Korh ${ }^{1,2}$, Etienne Deloule², Béatrice Luais ${ }^{2}$, Marie-Christine Boiron ${ }^{3}$, Luc \\ Bastian $^{4,5}$, Nathalie Vigier ${ }^{4}$
}

${ }^{1}$ Unit of Earth Sciences, Department of Geosciences, University of Fribourg, Chemin du Musée 6, CH-1700 Fribourg, Switzerland

${ }^{2}$ Centre de Recherches Pétrographiques et Géochimiques (CRPG), UMR 7358 CNRSUniversité de Lorraine, 15 rue Notre Dame des Pauvres, BP 20, F-54501 Vandœuvre-lèsNancy Cedex, France

${ }^{3}$ GeoRessources, Université de Lorraine, CNRS, UMR 7359, boulevard des Aiguillettes, BP 70239, F-54506 Vandœuvre-lès-Nancy, France

4Laboratoire d'Océanographie de Villefranche-sur-Mer (LOV), UMR 7093 Université Sorbonne-CNRS, 181 chemin du Lazaret, F-06230 Villefranche-sur-Mer, France

5Université de la Cote d'Azur, CNRS, Observatoire de la Côte d'Azur (OCA), Geoazur, UMR 7329, 250 rue Albert Einstein, Sophia-Antipolis, F-06500 Valbonne, France

*Corresponding author: afife.elkorh@unifr.ch

Keywords: lithium isotopes; hydrothermal alteration; subduction zone metamorphism; ophiolite; metabasite; serpentinite; ion-microprobe; ICP-MS 


\begin{abstract}
Ophiolites and high-pressure/low-temperature (HP-LT) terranes are important sites for the study of geochemical cycling in ancient oceanic lithosphere. We have analysed $\mathrm{Li}$ abundances and isotope composition in a series of ultrabasic and basic rocks from the Variscan Limousin ophiolite, as well as in basic and pelitic rocks from the lle de Groix HP-LT terrane. Both bulk and in-situ analyses are employed to evaluate Li mobility and isotope fractionation in the oceanic lithosphere during fluid-rock interactions related to seafloor and sub-seafloor hydrothermal alteration, subduction and exhumation processes.
\end{abstract}

In the Limousin ophiolite, early stages of high-temperature (high-T) hydrothermal alteration of oceanic ultrabasic rocks produce serpentine with low $\mathrm{Li}$ abundances (0.9-4.6 ppm) and low $\delta^{7} \mathrm{Li}\left(-8.9 \%\right.$ ). The $\delta^{7} \mathrm{Li}$ increase from -2.2 to $+4.2 \%$ in the following generations of serpentine during late-stage hydrothermal alteration results from changes in the fluid composition and temperature conditions. Therefore, even if dehydrating subducted serpentinites generate high amounts of fluids during subduction, abyssal serpentinites do not constitute an important source of $\mathrm{Li}$ for Li-rich metabasic rocks. In the associated amphibolites, hornblende displays typical $\mathrm{Li}$ contents (3.1-8.2 ppm) and isotopic compositions $(+3.5$ to $+12.5 \%$ ) similar to hydrothermally altered sheeted dykes and gabbros. By contrast, the low Li abundances and extremely high $\delta^{7} \mathrm{Li}$ values recorded by omphacite and pargasitic amphibole in the ultra-high-pressure (UHP) zoisite-eclogite from the Limousin probably reflect interaction with a heavy-Li sediment-derived fluid.

The HP-LT metabasites of the lle de Groix record different Li behaviour, with high Li abundances and low $\delta^{7} \mathrm{Li}$. They contain $\mathrm{Li}$ abundances significantly higher than fresh midocean ridge basalts (MORB) (16-124 ppm), indicating a metasomatic overprint by fluids derived from the neighbouring Li-rich micaschist (15-52 ppm) in addition to seawater during the early stages of subduction. Lithium is mainly hosted by: 1) glaucophane and omphacite in blueschists and eclogites; 2) chlorite and albite in retrograde greenschists; 3 ) phengite and chlorite in micaschists. The metabasites have $\delta^{7} \mathrm{Li}$ values of -4.8 to $+3.2 \%$ that are generally lower than fresh and altered MORB. The intercalated micaschists display $\delta^{7} \mathrm{Li}$ values ranging 
from -1.7 to $+0.2 \%$ o that are typical of subducted sediments. The $\delta^{7} \mathrm{Li}$ decrease from blueschists to eclogites from +1.8 to $-4.8 \%$, as well as the rimward $\delta^{7} \mathrm{Li}$ decrease in glaucophane from MORB-like $\delta^{7} \mathrm{Li}$ values to negative values in blueschists (core: -2.4 to $+8.8 \%$; rims: -7.1 to $+2.2 \%$ ), reveals that significant fluid-induced $\mathrm{Li}$ isotope fractionation occurred at the transition from the lawsonite-blueschist facies to the epidote-blueschist facies, and may be triggered by prograde lawsonite breakdown. In eclogites, the low $\delta^{7} \mathrm{Li}$ measured in whole rocks ( -4.8 to $-2.5 \%$ ), omphacite $(-22.4$ to $+3.3 \%)$ and glaucophane $(-6.9$ to $+1.4 \%$ ) indicates that $\mathrm{Li}$ isotope kinetic fractionation had stronger effects under eclogite facies conditions. The $\delta^{7} \mathrm{Li}$ increase toward positive values in the most retrogressed greenschist samples suggests Li mineral/fluid isotopic exchange during rehydration reactions and interaction with a Li-heavy fluid that is likely derived from the dehydrating metabasites. Thus, lithium isotope fractionation in the HP-LT rocks of the lle de Groix highlights migration of heavy-Li fluids along the oceanic crust-mantle interface in the subduction zone.

\section{INTRODUCTION}

Lithium, the lightest alkali metal with its two isotopes ${ }^{6} \mathrm{Li}$ and ${ }^{7} \mathrm{Li}$, is a fluid mobile element that can be used as a tracer of fluid-mediated mass transfer between oceanic crust and mantle in subduction zones (e.g. Brenan et al., 1998; Richter et al., 2003; Zack et al., 2003; Elliott et al., 2004; Marschall et al., 2007; Tang et al., 2010; Penniston-Dorland et al., 2010, 2012, 2017; Wan et al., 2017). Fresh MORB and mantle have generally low Li contents (3-8 ppm; Ryan \& Langmuir, 1987; Niu \& Batiza, 1997; Bouman et al., 2004; Tomascak et al., 2008), while Li can be abundant in the altered oceanic crust (1-119 ppm; Chan et al., 2002; Bouman et al., 2004; Coogan et al., 2017) and pelitic sediments (1-80 ppm; Bebout et al., 1993; Bouman et al., 2004; Chan et al., 2006). Interaction with heavy Li-rich seawater (+31\%; Millot et al., 2004) during hydrothermal alteration of the oceanic crust triggers $\mathrm{Li}$ isotope fractionation, resulting in a $\delta^{7} \mathrm{Li}$ increase in low-T altered rocks $(-1.7$ to $+20.8 \%$; Chan et al., 2002; Bouman et al., 2004; Coogan et al., 2017) compared to fresh MORB (+3.4 \pm 1.4\%; Tomascak et al., 2008). 
Devolatilisation reactions during subduction zone metamorphism (or HP-LT metamorphism) of Li-rich altered oceanic crust may release Li-rich fluids at shallow levels in subduction zones (e.g. You et al., 1996). Studies on HP-LT rocks have also observed that Li may be mobilised from metabasic (Marschall et al., 2006) and metasedimentary rocks (Bebout et al., 1993, 2007) during devolatilisation reactions at intermediate depths (40-100 $\mathrm{km})$, i.e. at the transition from blueschist to eclogite facies. However, significant amounts of $\mathrm{Li}$ are retained in blueschists and eclogites in amphiboles (glaucophane and, to a lesser extent, barroisite), pyroxenes (omphacite, aegyrine/jadeite) and high-pressure phengite (e.g. Woodland et al., 2002; Spandler and Hermann, 2006; John et al., 2008; El Korh et al., 2009, 2011). Scambelluri et al. (2004) have shown that the Li content of the serpentinised upper mantle does not vary during early hydrothermal processes and is preserved in high-pressure (HP) antigorite serpentinites. The serpentinised oceanic mantle can carry Li until depths $>100 \mathrm{~km}$, below which Li-rich fluids are released during antigorite breakdown, which is considered as a major source of fluids for arc lava magmatism (Scambelluri et al., 2004; Bouvier et al., 2008; Halama et al., 2011).

Lithium isotopes can fractionate during fluid-rock interactions related to subduction zone metamorphism (e.g. Zack et al., 2003; Marschall et al., 2007; Penniston-Dorland et al., 2010, 2012; Wan et al., 2017). Because of the large relative mass difference between the two isotopes (16\%; Tomascak, 2004) and the higher diffusivity of ${ }^{6} \mathrm{Li}$ compared to ${ }^{7} \mathrm{Li}$, the two Li stable isotopes can fractionate significantly by kinetic fractionation during chemical diffusion (Richter et al., 2003). With increasing metamorphic degree and temperature, kinetic isotope fractionation becomes predominant over equilibrium fractionation (Richter et al., 2003; Marschall et al., 2007). Kinetic isotope fractionation during fluid-rock interactions is enhanced by dissolution-precipitation reactions between mineral assemblages stable under varying P-T conditions (John et al., 2012). Variations in Li concentration and isotope composition in subduction-related rocks have been employed as tracers of metasomatic processes during subduction zone metamorphism (Marschall et al., 2007; Halama et al., 
2011; John et al., 2012; Penniston-Dorland et al., 2010, 2012, 2017; Taetz et al., 2016, 2018).

Recent studies have documented a wide range in $\mathrm{Li}$ isotopic composition resulting from metasomatic processes $(-6$ to $+14.5 \%$ ) in metabasic and metasedimentary rocks (Chan et al., 2006; Penniston-Dorland et al., 2010, 2012; Simons et al., 2010; Halama et al., 2011; Qiu et al., 2011; Romer \& Meixner, 2014; Coogan et al., 2017). Penniston-Dorland et al. (2012) have shown that the bulk $\delta^{7} \mathrm{Li}$ value of the metabasic rocks from the Catalina Schists (California, USA), a mélange HP terrane, reflects overprinting by fluids derived from the neighbouring metasediments rather than from low-T seafloor processes. Only small-scale reequilibration of the bulk $\delta^{7} \mathrm{Li}$ values and $\mathrm{Li}$ mobilisation were observed, despite of intense dehydration during subduction. However, Li mobilisation during sediment dehydration is not sufficient to reset the bulk $\delta^{7} \mathrm{Li}$ value of the metasediments (Penniston-Dorland et al., 2012).

Eclogites display a large range of $\mathrm{Li}$ compositions (1-94 ppm), and $\delta^{7} \mathrm{Li}$ values decreasing from MORB-like to extremely light values $(+6$ to $-21.9 \%$ with an average value of $-2.2 \pm 11.6 \%$; Zack et al., 2003; Marschall et al., 2007; Halama et al., 2011). At the blueschist to eclogite facies transition, significant amounts of $\mathrm{Li}$ (up to $60 \%$ of the whole rock content) can be mobilised by fluids from blueschists during devolatilisation reactions involving glaucophane and phengite in eclogitic selvages along a prograde dehydration fluid channel (Beinlich et al., 2010). At the same time, the $\delta^{7} \mathrm{Li}$ decreases during fluid-induced eclogitisation reactions towards fluid channels (John et al., 2012; Taetz et al., 2018). Li diffusion modelling and chronometry indicate that the time scale of fluid-rock interactions along vein channels during an individual fluid flow event is short-lived, with a duration on the order of $80-500$ years (John et al., 2012).

Different models were proposed to explain Li fractionation during subduction zone metamorphism. Based on whole rock and bulk omphacite analyses, Zack et al. (2003) show that the $\delta^{7} \mathrm{Li}$ value of the slab decreases progressively during subduction, according to the initial $\delta^{7} \mathrm{Li}$, the temperature and the amount of fluid released. Similarly, Agostini et al. (2008) interpret the correlation between the $\delta^{7} \mathrm{Li}$ and other tracers of slab-derived fluids as the result 
of significant $\mathrm{Li}$ fractionation towards low $\delta^{7} \mathrm{Li}$ at shallow depth during subduction. By contrast, the model of Marschall et al. (2007) suggests that the $\delta^{7} \mathrm{Li}$ of the subducting crust should only weakly decreases during subduction. They conclude that the light-Li signature recorded by orogenic eclogites is not only due to subduction-related metamorphism, but also results from the mobilisation of $\mathrm{Li}$ during eclogitisation or subsequent exhumation. This model predicts that the deeply subducted eclogites should have a higher $\delta^{7} \mathrm{Li}$ than the mantle.

Thus, the model defined by Marschall et al. (2007) shows that the heavy-Li fluids released into the fore-arc mantle wedge are consequently responsible for heavy-Li arc magmas or enriched MORB (E-MORB), distinct from lighter-Li normal-MORB (N-MORB) (Tomascak et al., 2000, 2002; Elliott et al., 2004, 2006). This expectation is supported by Li isotopic data from pore fluids and sediments in active subduction zone, which allowed estimation of $\delta^{7} \mathrm{Li}$ values of deep slab-derived fluids to vary between +22 and $+38 \%$ (Chan \& Kastner, 2000). In addition, oceanic crust recycling in subduction zones is thought to be the source of abnormal $\mathrm{Li}$ isotopic composition of mantle xenoliths ( -35 to $+8 \%$; Tang et al., 2007, 2010, 2012, 2014; Agostini et al., 2008; Wan et al., 2017) compared to the "normal" MORB mantle (+4 $\pm 2 \%$; Chan et al., 1992, 2002; Jeffcoate et al, 2007; Tomascak et al., 2008; Gao et al., 2011).

Lithium partitioning and isotope fractionation during fluid-rock interactions through hydrothermal alteration, subduction zone metamorphism and post-collision exhumation processes is still a matter of debate within the geoscience community. This study focuses on $\mathrm{Li}$ behaviour and isotope fractionation in a series of rocks from two units from the Moldanubian zone of the Variscan belt: 1) hydrothermally altered basic and ultrabasic rocks from the Limousin low-pressure ophiolite and 2) metabasic and metasedimentary rocks for the lle de Groix HP-LT terrane. It aims to examine Li mobility and isotopic fractionation in whole rocks and metamorphic minerals with regards to the variations of pressure and temperature and fluid-rock interactions during seafloor hydrothermal alteration and subduction zone metamorphism. We employ a novel approach combining bulk and in-situ 
elemental and isotopic analyses to investigate Li mobility during fluid-rock interactions related to low-T and high-T hydrothermal alteration, subduction-related devolatilisation and rehydration reactions in ancient oceanic rocks. The results will allow deciphering the modes of $\mathrm{Li}$ isotopic fractionation in remants of ancient Variscan oceanic lithosphere under various pressure and temperature conditions related to seafloor and sub-seafloor hydrothermal alteration, subduction and exhumation processes.

\section{GEOLOGICAL CONTEXT AND INVESTIGATED SAMPLES}

The Limousin and Ile de Groix areas are part of the European Variscan belt, which results from the Devonian to Carboniferous collision of two major continental domains, Laurussia (formed of Laurentia, Baltica and Avalonia) and Gondwana (Fig. 1a). The continental domains were separated by the Rheic and Palaeotethys Oceans, two major pre-Variscan oceanic domains opened during the Cambrian-Ordovician (e.g. Stampfli et al., 2011; Nance et al., 2010; von Raumer et al., 2013 Kroner and Romer, 2013). Three main collision events were involved during the Variscan orogeny: 1) Middle Devonian subduction of the oceanic crust under Gondwana and Laurussia, followed by the dislocation of the northern margin of the Gondwana; 2) Early Carboniferous continental collision between Avalonia-Laurussia and Gondwana-derived continental terranes; and 3) Late Carboniferous final collision (von Raumer et al., 2013; Kroner and Romer, 2013). The allochthonous domain (Moldanubian Zone; Fig. 1a) consists of superposed peri-Gondwanan nappes, and includes a series of Devonian ophiolites, which can be follow from the Sudetes to the Iberian Peninsula (see von Raumer et al., 2013, 2015 and references therein). The ophiolites are emplaced along the northern Gondwana margin, and derive from magmatic rocks that are contemporaneous with the Cambro-Ordovician rifting associated to the opening of the Rheic Ocean (von Raumer et al., 2013). In western France, the Limousin ophiolite and the lle de Groix blueschist terrane are recognised as remnants of rocks with oceanic affinity within the same Allochthon domain (Figs. 1b and c). 


\section{Limousin ophiolite}

The Limousin ophiolite belongs to the French Massif Central (FMC), which is part of the western European Variscan belt (e.g. Dubuisson et al., 1989; Berger et al, 2005; 2010a). Formation of the FMC results from the piling of a series of nappes during the Devonian-Early Carboniferous (Girardeau et al., 1986; Ledru et al., 1989, 1994; Demange, 1994; Faure et al., 2009): 1) the Upper Allochthon, called Gartempe Unit in the North Limousin, corresponds to a group of low-grade Palaeozoic rocks; 2) the Middle Allochthon (Upper Gneiss Unit), is a composite unit that contains rocks from the "leptyno-amphibolite groups" (LAGs) (Santallier et al., 1988), formed by paragneisses, leptynites and amphibolites of medium to high grade metamorphism, as well as migmatitic metagreywackes and relicts of eclogites and granulites; 3) the Lower Allochthon (Lower Gneiss Unit) consists of metasediments (paragneisses, micaschists, metashales and metagreywackes) and Late Proterozoic-Early Cambrian and Ordovician leucocratic orthogneisses; 4) the Parautochthon basement, deriving from metasediments and metagranites; and 5) the Southern Palaeozoic Nappes, corresponding to continental margin/platform series.

The Limousin ophiolite occurs as a $25 \mathrm{~km}$ long belt of basic and ultrabasic rocks, located in the upper part of the Middle Allochthon unit (Fig. 1b). It consists of a series of 1-5 $\mathrm{km}$ wide ophiolite massifs segmented by Variscan and late Carboniferous faults (Berger et al., 2005, 2006). Based on petrological and geochemical data, the Limousin ophiolite has been interpreted as the remnants of an ancient oceanic lithosphere (Dubuisson et al., 1989; Berger et al., 2005, 2006). It corresponds to a Iherzolite-harzburgite ophiolite type, emplaced in a slow-spreading mid-ocean ridge (Berger et al., 2006). Main lithologies include diopsidebearing harzburgites, harzburgites, dunites, wehrlites, troctolites, (meta)gabbros and amphibolites (Berger et al., 2005). The ultrabasic rocks are highly serpentinised, with only rare relicts of olivine, spinel or pyroxene. Alteration of abyssal peridotites and amphibolitefacies metamorphism of the gabbros and mafic dykes result from intensive seafloor hydrothermal alteration under low-P conditions $(\sim 0.2 \mathrm{GPa})$ and temperature decreasing from 
high-T late-magmatic conditions to greenschist-zeolite metamorphic facies, following magma emplacement (Berger et al., 2005).

The base of the Middle Allochthon unit also includes lenses of high-pressure (HP) to ultra-high-pressure (UHP) zoisite-eclogites, zoisite-kyanite-eclogites and kyanite-eclogites (Berger et al., 2010a). Eclogites were formed by deep subduction at a depth of $100 \mathrm{~km}$ (P $\left.2.9 \pm 0.5 \mathrm{GPa}, \mathrm{T} \sim 660 \pm 70^{\circ} \mathrm{C}\right)$. Ultra-high-pressure eclogites show variable degrees of fluidrock interactions. Kyanite-eclogites have a composition similar to supra-subduction zone basalts and were relatively preserved from metasomatism (Berger et al., 2010a). Zoisiteeclogites were interpreted as former iron-rich plagioclase cumulates and display geochemical evidences of interaction with fluids derived from subducted terrigenous sediments during the UHP metamorphic stage (Berger et al., 2010a). Geochronological data show that the zoisiteeclogite has recorded a protolith age of 475-489 Ma (U-Pb; zircon) (Berger et al., 2010a). Crystallisation of the magmatic protolith of the UHP eclogites is contemporaneous to the emplacement of the orthogneisses from the Lower Allochthon unit (446 \pm 6 to $521 \pm 7 \mathrm{Ma}$; Melleton et al., 2010) and occurred during the Cambro-Ordovician rifting. The UHP event was dated at $412 \pm 5 \mathrm{Ma}$ (Berger et al., 2010a).

In this study, we have investigated the Li trace element and isotope composition in six serpentinites, four amphibolites and one zoisite-eclogite from La Flotte, Le Cluzeau and Saint-Laurent ophiolite massifs (Fig. 1c; Table 1). The whole rock compositions are given in the Supplementary Table A1. Serpentinites display the typical mesh textures resulting from hydrothermal alteration of ultrabasic rocks at mid-ocean ridges (Bach et al., 2006), with brown serpentine cores rimmed by a second yellow generation (Figs. 2a and b). The serpentinites from Saint-Laurent (LAU1, LAU2) are rich in MgO, and show low abundances of $\mathrm{Fe}_{2} \mathrm{O}_{3}, \mathrm{FeO}, \mathrm{Al}_{2} \mathrm{O}_{3}$ and $\mathrm{CaO}$. They consist of an assemblage of Mg-rich serpentine, chlorite forming veins, spinel, amphibole (composition from tremolite to Mg-hornblende) and rare relicts of olivine (Fig. 2a). These samples may correspond to the highly serpentinised dunites described by Dubuisson et al. (1989). Core parts of serpentine are slightly richer in FeO. Serpentine along contact zones with chlorite veins are also richer in $\mathrm{FeO}$ and contain 
Fe-hydroxides. The serpentinites from La Flotte (FLOT1, FLOT2a, FLOT2b) and Le Cluzeau (CLUZ6) are slightly richer in $\mathrm{Al}_{2} \mathrm{O}_{3}, \mathrm{Fe}_{2} \mathrm{O}_{3}$ and $\mathrm{FeO}$, and have a lower $\mathrm{XMg}$ than samples from Saint-Laurent. They are composed of serpentine that have partially to totally replaced olivine and pyroxene, and also contain large lenses of chlorite + amphibole (tremolite to Mghornblende), spinel, iron oxides and sulphides (Fig. 2b). Serpentine is often zoned in FeO and $\mathrm{MgO}$, displaying a rimward increase of the Mg\# (Supplementary Table A2). These samples may be related to the serpentinised harzburgites or troctolites described by Dubuisson et al. (1989) and Berger et al. (2005). The studied amphibolites consist of two fine grained slightly foliated amphibolites (CLUZ 1 and CLUZ 1a) and two isotropic amphibolites (CLUZ 4 and CLUZ 5), which derive from isotropic or layered gabbros (Berger et al., 2005). They display an assemblage of green-brown amphibole (mainly Mg-hornblende), plagioclase, chlorite and iron oxides (Figs. 2c and d). Magmatic plagioclase relicts are sometimes present. Amphibole often shows evidences of alteration in iron hydroxydes along grain rims and fractures. The studied zoisite-eclogite L04-143 (from Berger et al. 2010a) is composed of garnet, zoisite, omphacite, pargasitic amphibole, and rutile rimmed by ilmenite.

\section{lle de Groix}

The lle de Groix (Armorican Massif, France) corresponds to the outcropping part of a HP-LT unit, also located in the Middle Allochthon unit of the Variscan belt. The metamorphic rocks of the lle de Groix are composed of $20 \%$ metabasic rocks of hydrothermally altered E-MORB affinity interlayered with $80 \%$ pelitic micaschists (Audren et al., 1993; Bernard-Griffiths et al., 1986; Bosse et al., 2002; El Korh et al., 2009, 2013, 2017a) (Fig. 1c). The rocks recorded two metamorphic phases: 1) a prograde blueschist to eclogite facies metamorphism M1 related to subduction, and 2) a greenschist facies overprint M2 related to exhumation (e.g. Carpenter, 1976; Quinquis, 1980; Quinquis \& Choukroune, 1981; Barrientos \& Selverstone, 1993; Bosse et al., 2002; Ballèvre et al., 2003; El Korh et al., 2009, 2013). The eastern part of the lle de Groix is dominated by eclogites, and epidote-blueschist facies rocks, whereas greenschist facies rocks are dominant on the western part. The difference in mineral 
assemblages between eclogites and epidote-blueschist facies metabasites may result from small variations in the protolith composition and by small differences in temperature (50$75^{\circ} \mathrm{C}$ ) for the peak metamorphic conditions (El Korh et al., 2009). The peak P-T conditions, estimated at $1.6-2.5 \mathrm{GPa}$ and $500-600^{\circ} \mathrm{C}$ in eclogites correspond to the blueschist to eclogite facies transition, which is expected to have taken place at c. $60-70 \mathrm{~km}$ depth in a subduction zone with an intermediate thermal regime (El Korh et al., 2009). Based on P-T calculations using the NFMASH system for metapelites, Bosse et al. (2002) have defined two metamorphic units divided by a ductile thrust: the Upper Unit $\left(1.6-1.8 \mathrm{GPa}, 450-500^{\circ} \mathrm{C}\right)$ in the eastern part of the island, and the Lower Unit $\left(1.4-1.6 \mathrm{GPa}, 400-450^{\circ} \mathrm{C}\right)$ in the West.

The HP-LT event was dated at 358-365 Ma with the ${ }^{40} \mathrm{Ar} /{ }^{39} \mathrm{Ar}$ (phengite) and $\mathrm{Rb}-\mathrm{Sr}$ (whole rock, phengite and epidote) methods, while a younger age of 345-353 Ma was determined for the greenschist metamorphic event (Bosse et al., 2005). Rare albite gneisses interlayered within micaschists and chloritoschists on the lle de Groix provided protolith ages of $480.8 \pm 4.8 \mathrm{Ma}$ and $492.7 \pm 3.2 \mathrm{Ma}$, respectively $(\mathrm{U}-\mathrm{Pb}$ dates on zircon; El Korh et al., 2012; Paquette et al., 2017), contemporaneous with the Cambro-Ordovician rifting, widely recognised in the internal parts of the Variscan belt (e.g. von Raumer et al., 2013). Fe isotope measurements have shown that the metabasites of the lle de Groix derive from an unusual heavy-Fe mantle source, and were probably emplaced during the intracontinental back-arc basin rifting that occurred along the northern Gondwana margin after the closure of the Proto-Rheic ocean (von Raumer et al., 2015; El Korh et al., 2017a). During the Variscan subduction, the metabasalts and their sedimentary cover were sheared off and imbricated in an accretionary prism (El Korh et al. 2012).

Based on trace element and $\delta^{18} \mathrm{O}$ analyses, El Korh et al. (2013) have shown that large-scale fluid-rock interactions occurred as open system only during seafloor hydrothermal alteration and early subduction prograde metasomatism. The retrograde metamorphism was interpreted as an overprint of fluids likely derived from the basic rocks without involving infiltration of externally derived fluids at $\mathrm{P}-\mathrm{T}$ conditions lower than $1 \mathrm{GPa}$ and $400^{\circ} \mathrm{C}(\mathrm{El} \mathrm{Korh}$ et al., 2011). Metabasites that underwent pervasive alteration by pre-HP metasomatism 
processes, show greater effects of retrogression (El Korh et al., 2013). Consequently, the large-scale zonation of the lle de Groix was interpreted as the result of superimposed effects of the low-temperature hydrothermal alteration and variable dehydration states due to distinct peak P-T conditions in the two tectonic units (Bosse et al., 2002; El Korh et al., 2013).

Peak metamorphic assemblages in metabasites (blueschists and eclogites) are composed of garnet, glaucophane, epidote, phengite, apatite, quartz, titanite and/or rutile. Omphacite porphyroblasts are only present in eclogites (Figs. 2e and f). Blueschist facies rocks often contain pseudomorphs after lawsonite, composed of epidote, white mica (phengite, paragonite), actinolite, and albite (Ballèvre et al., 2003). Partial retrogression of eclogites and blueschists is evidenced by: 1) barroisite + albite symplectites replacing omphacite, 2) barroisite and actinolite overgrowths along glaucophane rims, and 3) partial replacement of garnet by chlorite and rutile by titanite (Figs. 2e and f). Retrograde assemblages in greenschists correspond to epidote, chlorite, actinolite, barroisite, albite, magnetite, and titanite. High-pressure garnet is partially to totally replaced by chlorite, actinolite and by a retrograde generation of epidote. "Albitic greenschists" contain large albite porphyroblasts \pm calcite, and have experienced intensive fluid-rock interactions during retrogression (El Korh et al., 2013).

Eighteen samples were studied, typical of each metamorphic facies and lithology (Fig. 1b; Table 1). They include thirteen metabasites (blueschists GR02, 04, 11b, 12b, 25a and GROA56; eclogites GR21, 24a and 29; greenschists GR06a, 23 and 25b, and albitic greenschists GROA43 and 52), two blueschist-facies metapelites (GROA110 and 111a) and two greenschist-facies metapelites (GR26b and GROA104). For the detailed description of the samples, see El Korh et al. $(2009,2011,2013)$.

\section{ANALYTICAL TECHNIQUES}

\section{Whole rock Li elemental and isotopic composition}

The whole rock $\mathrm{Li}$ abundances in the samples from the lle de Groix and Limousin were measured using a Varian 220FS Atomic Absorption Spectrometer at the SARM (Service 
d'Analyse des Roches et Minéraux; CRPG, Nancy). $1 \sigma$ uncertainties are 2\%, 5\%, $10 \%$ and $20 \%$ for abundances of $>100 \mathrm{ppm}, 50-100 \mathrm{ppm}, 10-50 \mathrm{ppm}$ and $0.5-10 \mathrm{ppm}$, respectively.

The $\mathrm{Li}$ isotope analyses of the whole rock samples from the lle de Groix and separated glaucophane and omphacite from sample GR29 were analysed at the CRPGNancy. Lithium was separated following the procedure detailed in Vigier et al. (2008; modified after James \& Palmer, 2000). In summary, $10 \mathrm{mg}$ of powdered samples were dissolved in three steps using: 1) a 2:1 mixture of $\mathrm{HF}(28 \mathrm{~N})$ and $\mathrm{HNO}_{3}(15 \mathrm{~N})$ on a hot plate at $120^{\circ} \mathrm{C}$; 2) $\mathrm{HNO}_{3}(15 \mathrm{~N})$ at $60^{\circ} \mathrm{C}$; and 3$) \mathrm{HCl}(1 \mathrm{~N})$ at $60^{\circ} \mathrm{C}$. The total dissolution of the samples took approximately 1 week. After total dissolution of the samples and centrifugation, $\mathrm{Li}$ was eluted and purified through cationic AG50X12 resin-exchange chromatography columns. The same chemical procedure has been applied to blank solutions. Chemistry blanks were systematically less than $15 \mathrm{pg} \mathrm{Li}$.

Lithium isotopes were measured by multi-collector inductively coupled plasma mass spectrometry (MC-ICPMS) using a NeptunePlus instrument (ThermoFisher Scientific, Germany and USA) at the CRPG-Nancy. Samples were introduced in the MC-ICPMS via a cyclonic spray chamber. The instrument was operating in static mode at a low resolution $(\mathrm{M} / \Delta \mathrm{M}=400)$. The cup configuration consisted of: Low 4 ( $\left.{ }^{6} \mathrm{Li}\right)$ and High 4 ( $\left.{ }^{7} \mathrm{Li}\right)$. The gas flow rates, torch parameters and ion lenses were optimised using a solution of the NIST L-SVEC RM $8545 \mathrm{Li}$ standard. The correction coefficients between the Faraday cups were obtained by a gain calibration before optimising the peak shapes and centring the peaks. Analyses were performed on $25 \mathrm{ppb} \mathrm{Li}$ solutions, diluted in $\mathrm{HNO}_{3}(0.05 \mathrm{~N})$. Thirty-five integration cycles were measured during $294 \mathrm{~s}(+300 \mathrm{~s}$ take up time), after a washout time of $440 \mathrm{~s}$ in $\mathrm{HNO}_{3}(0.05 \mathrm{~N})$ and a background measurement of $67 \mathrm{~s}$.

Typical acquisition series consisted of alternate measurements of the L-SVEC standard and a sample. Each measurement is corrected for the background value (measured in $0.05 \mathrm{~N} \mathrm{HNO}_{3}$ ). Background intensities for the ${ }^{7} \mathrm{Li}$ isotope were $0.06-0.1 \mathrm{~V}$. Backgroundcorrected intensities for the ${ }^{7} \mathrm{Li}$ isotope were $\leq 0.01 \mathrm{~V}$ for blank solutions, and generally $2-3 \mathrm{~V}$ for standards and samples solutions. The $\mathrm{Li}$ isotope ratios normalised to the L-SVEC 
standard, expressed as $\delta^{7} \mathrm{Li}_{\mathrm{L}-\mathrm{SVEC}}$, were calculated using the sample standard bracketing method (SSB), as follows:

$\%$ o $\delta^{7} \mathrm{Li}_{\mathrm{L}-S V E C}($ sample $)=\left[\left({ }^{7} \mathrm{Li} /{ }^{6} \mathrm{Li}\right)_{\text {sample }} /\left({ }^{7} \mathrm{Li} /{ }^{6} \mathrm{Li}\right)_{\mathrm{L}-S V E C}-1\right] \times 1000$

The $\mathrm{Li}^{7} \mathrm{~N}$ standard (nominal $\delta^{7} \mathrm{Li}$ value: $+30.1 \%$; $+30.1 \pm 1.1 \%$ to $+30.2 \pm 0.3 \%$; Carignan et al., 2007) served as external secondary standard to monitor the accuracy and the precision of the isotopic measurements. An average $\delta^{7} \mathrm{Li}$ value of $+30.1 \pm 0.2 \%$ was obtained $(2 \sigma \mathrm{SE}$ as external reproducibility; $n=12$ ), consistent with the reference and published values. The $\delta^{7} \mathrm{Li}_{\mathrm{L}-S V E C}$ of the samples is calculated by averaging replicate analyses of the same sample solution. For this reason, uncertainties are given as $2 \sigma$ standard errors $(2 \sigma \mathrm{SE})$.

\section{XRD measurements}

The serpentine species in sample FLOT2b were characterised on a $50 \mu \mathrm{m}$ polished thin section using a Rigaku Ultima IV X-ray diffractometer (XRD) at the University of Fribourg (Switzerland). Analyses were carried out in continuous scan mode using Bragg-Brentano geometry. Operating conditions included a $2 \theta$ step size of $0.02 \%$ step, a counting time/step of $0.5^{\circ} / \mathrm{min}$ between 5 and $70^{\circ}$, and X-ray tube conditions of $40 \mathrm{kV}$ and $40 \mathrm{~mA}(\mathrm{Cu} \mathrm{K \alpha})$. The detection limit for mineral determination is c. $5 \mathrm{wt} \%$. The mineral assemblage was identified using the software PDXL2 (Rigaku).

\section{Determination of mineral Li abundances}

\section{Limousin ophiolite}

Because of the low Li content of serpentinites and amphibolites, the mineral Li abundances in the rocks of the Limousin area were measured by secondary ion mass spectrometry (SIMS) using a Cameca ims1280 instrument at the CRPG. Analyses were performed on gold-coated thin sections, using a 8-14 nA primary projected $0^{-}$beam with 15-20 $\mu \mathrm{m}$ spot size. Secondary ions were measured by peak hopping in monocollection mode using SEM 
detector for ${ }^{7} \mathrm{Li}$, and Faraday cup $\mathrm{FC} 2$ for ${ }^{28} \mathrm{Si}$, at a resolution of $1500(\mathrm{M} / \Delta \mathrm{M})$. The primary and secondary beam accelerating voltages were $-13 \mathrm{kV}$ and $+10 \mathrm{kV}$, respectively. Analyses were performed using a $28 \mathrm{eV}$ energy window, with an energy offset of $-50 \mathrm{eV}$. 20 integration cycles were measured during c. $15 \mathrm{~min}$, after 120 s of pre-sputtering. Si was employed as internal standard, using the mineral $\mathrm{SiO}_{2}$ content (see Electronic Appendix). Reference basaltic glasses KL2-G (5.1 ppm Li; 50.5\% $\mathrm{SiO}_{2}$ ) and $\mathrm{StHs60/80-G} \mathrm{(20.7} \mathrm{ppm} \mathrm{Li;} \mathrm{63.7 \%}$ $\mathrm{SiO}_{2}$ ) of the Max-Planck-Institut-Dingwell (MPI-DING) served as external standards to determine the $\mathrm{Li}$ ionisation yield relative to $\mathrm{Si}$, as a function of the sample $\mathrm{Si}$ content. The daily $2 \sigma$ external reproducibility of the standards, given as $2 \sigma$ standard error $(2 \sigma$ SE), was $0.69-1.8 \%$.

Ile de Groix

A part of the $\mathrm{Li}$ abundances in minerals from the samples of the lle de Groix were analysed by laser ablation inductively coupled plasma mass spectrometry (LA-ICPMS) during previous studies (El Korh et al., 2009; El Korh, 2010). Supplementary Li abundances in minerals from the samples of the Ile de Groix were performed by LA-ICPMS at the GeoRessources laboratory, University of Lorraine (Vandœuvre-lès-Nancy, France). The instrument consists of an Agilent 7500c quadrupole ICPMS interfaced to a GeoLas Pro $193 \mathrm{~nm}$ ArF excimer laser ablation system (Lambda Physik, Germany). The laser was operating at a $5 \mathrm{~Hz}$ repetition rate, a fluence of $\sim 10 \mathrm{~J} / \mathrm{cm}^{2}$, and a $44 \mu \mathrm{m}$ spot size. Helium was used as the cell gas $(0.8 \mathrm{~L} / \mathrm{min})$ and was mixed with Ar prior to its introduction in the plasma $(1.5 \mathrm{~L} / \mathrm{min})$. Peak hopping mode was employed, as well as dual (counting and analogue) secondary electron multiplier (SEM) detector mode. Dwell times were $20 \mathrm{~ms}$ for ${ }^{7} \mathrm{Li}$ and $10 \mathrm{~ms}$ for ${ }^{42} \mathrm{Ca}$ and ${ }^{29} \mathrm{Si}$. The ${ }^{248} \mathrm{ThO}^{+} / 232 \mathrm{Th}^{+}$and $\mathrm{Ca}^{2+} / \mathrm{Ca}^{+}$ratios were optimised to about $0.3-0.7$ and $0.3-0.5 \%$ respectively, by ablation of the National Institute of Standards and Technology reference material SRM 610, a synthetic glass doped with trace elements. Acquisition times for background and ablation intervals amounted to 60 and $40 \mathrm{~s}$, respectively. The NIST SRM 610 reference material was employed as external standard, using the preferred values of 
average element abundances from the GeoRem database (Max Planck Institut für Chemie, Mainz, Germany; http://georem.mpch-mainz.gwdg.de).

Analytical series consisted of 10-16 measurements of samples, bracketed by a run of 2 measurements of the standard before and after the samples. Intensity vs. time data were reduced using an Excel spreadsheet, following the procedure defined in Longerich et al. (1996). Internal standards were ${ }^{42} \mathrm{Ca}$ (epidote, garnet, omphacite, titanite, calcite) and ${ }^{29} \mathrm{Si}$ (glaucophane, albite, chlorite, phengite), based on the mineral major element compositions (El Korh et al., 2009). Intervals of 45 and 25 s were selected for the background and the ablation signal, respectively, with an offset of $3 \mathrm{~s}$ from the beginning of the ablation. No correction for down-hole fractionation was applied. The instrumental mass bias was corrected using a linear regression function, considering an equal time interval between each analysis. The minimum detection limit, corresponding to three times the standard deviation of the net background measurement, is based on the $99 \%$ confidence level over the Gaussian counting statistics. Limits of detection were 1.5-20 ppm. Uncertainties on individual measurements at $1 \sigma$ are generally $2.0-12 \%$. The NIST SRM 612 glass was employed as secondary standard and yielded a Li concentration of $39.4 \pm 2.2 \mathrm{ppm}(95 \%$ confidence level $(C L) ; n=11)$, similar within uncertainty to the GeoRem preferred value $(40.2 \pm 1.3 p p m ; 95 \%$ $\mathrm{CL})$.

\section{In-situ Li isotope analysis in minerals}

In-situ Li isotopes in minerals were measured on gold-coated thin sections by SIMS using a Cameca ims1280 instrument at the CRPG. Analyses in the Li-rich minerals (omphacite and glaucophane from the metabasites of the lle de Groix) were performed using a 5.3-6.3 nA projected primary $\mathrm{O}^{-}$beam with c. $20 \mu \mathrm{m}$ spot size. The Li-poor minerals (serpentine, olivine and hornblende in the samples from the Limousin) were analysed using a 15-20 nA focused primary $\mathrm{O}^{-}$beam with c. $35 \mu \mathrm{m}$ spot size. Secondary ${ }^{6} \mathrm{Li}$ and ${ }^{7} \mathrm{Li}$ ions were measured by peak hopping in monocollection mode using SEM detector for intensities $<5.10^{5} \mathrm{cps}$, and FC2 detector for intensities $>5.10^{5} \mathrm{cps}$, at a resolution of $1500(\mathrm{M} / \Delta \mathrm{M})$. The primary and 
secondary beam accelerating voltages were of $-13 \mathrm{kV}$ and $+10 \mathrm{kV}$, respectively. Analyses were performed using a $50 \mathrm{eV}$ energy window, without energy offset. 20 integration cycles were measured during c. 20 min, after 120 s of pre-sputtering.

Studies of matrix effects during Li isotope analyses by SIMS (Decitre et al., 2002; Kasemann et al., 2005) have shown that there is no significant matrix dependence on the $\delta^{7} \mathrm{Li}$ values between different mineral phases with close Mg\#. Besides, matrix effects occur if the Mg\# value of standards and samples varies. External calibration to the L-SVEC and correction of the daily instrumental fractionation was performed using a series of clinopyroxenes, olivine and orthopyroxenes of various $M g \#$ and $\delta^{7} L_{L} i_{\text {-SVEC }}$ values, which were measured at the beginning and at the end of each analytical series (Decitre et al., 2002; Su et al., 2015; see the Supplementary Table A3 for the detailed list of the standards). $1 \sigma$ internal errors on individual measurements were $0.3-2.7 \%$. 1 -day $2 \sigma$ external reproducibility of the standards was $0.4-2.7 \%$ ( $2 \sigma \mathrm{SE})$.

During this study, no significant variation of the instrumental mass bias between different phases of similar Mg\# (e.g. olivine, clinopyroxene and glass) occurred. Therefore, we observed a variation of the instrumental mass bias with the Mg\#. As the Mg\# of the studied samples of the Ile de Groix is significantly lower than that of standards $(0.52-0.66$ and $0.86-0.92$, respectively), we have calculated the mass bias, or instrumental mass fractionation (IMF), for the sample from the lle de Groix as follow: IMF $=\alpha{ }^{*} \mathrm{Mg} \#+\beta$. Coefficients $\alpha$ and $\beta$ were obtained by a linear regression using the mean IMF value plotted against the mean Mg\# of the various standards. We have also employed MC-ICPMS data of mean glaucophane and omphacite from eclogite GR 29 to constrain the linear regression. The final $\delta^{7} \mathrm{Li}$ values, relative to the NIST L-SVEC RM 8545, are calculated as follow: $\delta^{7} \operatorname{Li}_{\text {LSVEC }}($ sample $)=\delta^{7}$ Li LSVEC $_{\text {LSIMS })}-$ IMF. Minerals from the Limousin ophiolite with a lower $\mathrm{Mg \#}(0.71-0.77)$ than standards were corrected as well.

During the different sessions, no significant variation of the measured $\delta^{7} \mathrm{Li}$ could be observed in association with the orientation of the serpentine, chlorite or amphibole minerals, 
when compared to the 1-day $2 \sigma$ external reproducibility. This agrees with the observation of Siron et al $(2017,2018)$ for $\delta^{18} \mathrm{O}, \mathrm{H}_{2} \mathrm{O}, \mathrm{F}$ and $\mathrm{Cl}$ in-situ measurement by SIMS on biotite.

In this study, the range of mineral $\delta^{7} \mathrm{Li}$ values in each sample is discussed using mean $\delta^{7} \mathrm{Li}$ values. Despite large $2 \sigma \mathrm{SD}$ uncertainties due to mineral heterogeneities, the mean $\delta^{7} \mathrm{Li}$ values are employed to calculate the fractionation factors between mineral pairs and whole rocks. This makes it possible to minimise extreme values, which can be unrepresentative, especially since no outlier rejection is undertaken. Fractionation factors between minerals and whole rocks provide information on $\mathrm{Li}$ isotopic equilibrium or disequilibrium, as well as on the extent of $\mathrm{Li}$ isotope fractionation, during the various stages of hydrothermal alteration and subduction zone metamorphism.

\section{RESULTS}

\section{Li elemental and isotopic composition in the rocks from the Limousin ophiolite}

Whole rocks

The studied serpentinites from the Limousin ophiolite have Li abundances of 2.4-4.6 and 0.9-3.0 ppm, respectively. The UHP eclogite has a Li content of $2.3 \mathrm{ppm}$, while the amphibolites display significant higher $\mathrm{Li}$ contents $(3.1-8.2 \mathrm{ppm})$. These values are comparable with the range of values of fresh MORB (3-8 ppm) (Ryan \& Langmuir, 1987; Niu \& Batiza, 1997) and altered MORB (1-119 ppm; Chan et al., 2002; Bouman et al., 2004; Coogan et al., 2017) (Fig. 3; Table 2).

\section{Minerals}

Minerals from the Limousin ophiolite generally display low Li abundances (Fig. 3 and Table 3). In serpentinites, serpentine is the main host for $\mathrm{Li}(0.33-8.2 \mathrm{ppm})$. Lithium abundances in Fe-richer serpentine (1.2-8.2 ppm) are generally higher than in Mg-rich serpentine (0.33-3.6 ppm). The less abundant olivine and amphibole (tremolite to Mg-hornblende) display similar Li contents as Mg-rich serpentine (1.5-3.0 and 1.1-3.5 ppm, respectively), while chlorite has low Li abundances (0.24-1.0 ppm). In amphibolites, Li abundances are higher in hornblende 
$(1.3-11 \mathrm{ppm})$ than in plagioclase $(0.09-1.0 \mathrm{ppm})$. In the UHP zoisite-eclogite, Li is mainly hosted by pargasitic amphibole (1.5-31 ppm) and omphacite (1.5-10 ppm), while low Li concentrations are measured in garnet $(0.15-0.90 \mathrm{ppm})$ and zoisite $(0.03-0.38 \mathrm{ppm})$.

The detailed study of serpentinite LAU2 shows that serpentine has a mean $\delta^{7} \mathrm{Li}$ value of $-8.9 \pm 5.2 \%$ o $(2 \sigma \mathrm{SD})$. Altered serpentine, richer in $\mathrm{FeO}$, has a similar $\delta^{7} \mathrm{Li}$ value of $-8.7 \pm$

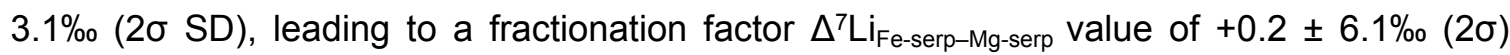
(Table 3). Even if the two generations of serpentine are identical within uncertainty, the large $2 \sigma$ SD values result from mineral heterogeneities, which are probably related to local isotopic disequilibria during hydrothermal alteration processes. Serpentine from the sample FLOT-2a has a $\delta^{7} \mathrm{Li}$ value of $-2.5 \pm 5.5 \%$ o ( $\left.2 \sigma \mathrm{SD}\right)$, while relicts of olivine have a $\delta^{7} \mathrm{Li}$ value of $+6.3 \pm$

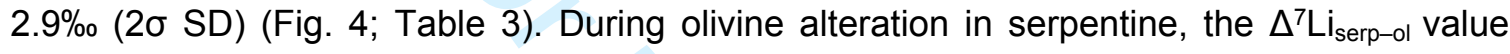
amounts to $-8.8 \pm 6.3 \%$ o $(2 \sigma)$ (Table 3 ; Fig. $4 a$ ). Serpentine from sample CLUZ6 is strongly zoned in $\delta^{7} \mathrm{Li}$ : Fe-rich cores, replacing olivine, have a $\delta^{7} \mathrm{Li}$ of $-2.2 \pm 3.0 \%$ and $\mathrm{Mg}$-rich rims have a $\delta^{7} \mathrm{Li}$ of $+4.2 \pm 3.5 \%$ ( $2 \sigma \mathrm{SD}$ ). Co-existing amphibole (tremolite to Mg-hornblende) has

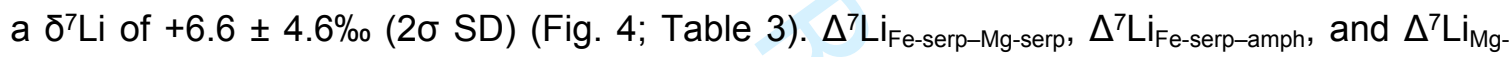
serp-amph values correspond to $-6.4 \pm 4.6,-8.8 \pm 5.5$ and $-2.5 \pm 5.8 \%$, respectively (Table 3 ).

Hornblende in amphibolite CLUZ1 has a MORB-like $\delta^{7} \mathrm{Li}$ of value of $+3.5 \pm 4.4 \%$ o $(2 \sigma$ $S D)$. A higher value of $+9.8 \pm 0.9 \%$ o $(2 \sigma S D)$ was recorded in altered parts. Hornblende in amphibolite CLUZ4 (metagabbro) has a higher value of $+12.5 \pm 9.6 \%$ ( $2 \sigma \mathrm{SD})$ (Table 3 ).

In the UHP zoisite-eclogite L04-143, omphacite is the main host for Li during the UHP metamorphic stage. It has a positive $\delta^{7} \mathrm{Li}$ value of $+21.9 \pm 5.0 \%$ ( $\left.2 \sigma \mathrm{SD}\right)$ (Fig. 4; Table 3). Secondary pargasitic amphibole has a $\delta^{7} \mathrm{Li}$ value of $+18.7 \pm 7.2 \%$ ( $2 \sigma \mathrm{SD}$ ). The resulting $\Delta^{7} \mathrm{Li}_{\text {amph-omph }}$ value consists of $-3.3 \pm 8.7 \%$ o $(2 \sigma)$ and indicates that isotopic equilibrium between omphacite and amphibole is not globally reached during partial retrogression, even if mineral pairs may be locally in equilibrium (Table 3 ).

\section{Li elemental and isotopic composition in the rocks from the lle de Groix}

Whole rocks 
The metabasites of the lle de Groix have Li abundances of 16-124 ppm (Table 4). These values are significantly higher than those of fresh MORB and Limousin UHP eclogite. Even if they cover a large range of values, the Li concentrations of the metabasites of the lle de Groix do not vary according to the different metamorphic facies (Fig. 5) but are controlled by the mineral assemblage (Fig. 5). The studied micaschists have Li contents of $15-52 \mathrm{ppm}$, in agreement with the values measured in subducted metasediments (2-78 ppm, Bouman et al., 2004; Chan et al., 2006). No change of Li concentration is observed between blueschist and greenschist facies micaschists.

The metabasites have $\delta^{7} \mathrm{Li}$ values of $-4.8 \pm 0.5$ to $+3.2 \pm 0.6 \%$ ( $2 \sigma$ SE) (Fig. 6a; Table 4) that are generally lower than those of fresh MORB $(+3.4 \pm 1.4 \%$, $2 \sigma$; Tomascak et al., 2008). Most samples have $\delta^{7} \mathrm{Li}$ within the range of data for heavy-Li low-T altered oceanic crust (-1.7 to $+20.8 \%$; Chan et al., 2002; Coogan et al., 2017). Even if Li abundances do not show any correlation with the metamorphic facies, the $\delta^{7} \mathrm{Li}$ values of the metabasites vary between the metamorphic stages (Figs. $6 a$ and b). The $\delta^{7} \mathrm{Li}$ values of blueschists vary from $0.6 \pm 0.3$ to $+0.7 \%$ o ( $2 \sigma \mathrm{SE})$, i.e. from MORB-like values to lower negative values. Eclogites have negative $\delta^{7} \mathrm{Li}$ values ranging from -4.8 to $-2.5 \%$, which are lower than those of the lowT altered oceanic crust (Fig. 6; Table 4). Greenschists show a larger range of $\delta^{7} \mathrm{Li}$ values from $-4.5 \pm 0.5$ to $+3.2 \pm 0.6 \%$ o ( $2 \sigma \mathrm{SE})$. Greenschists that underwent restricted fluid rock interactions during retrogression (GR23 and 25b) display negative values ( $-4.5 \pm 0.5$ to $-0.1 \pm$ $0.5 \%$ ). Greenschists displaying a higher degree of retrogression and rehydration (GR06 and albite-bearing greenschist GROA52) have positive values of $+1.5 \pm 0.4$ to $+3.2 \pm 0.6 \%$ (Fig. 6; Table 4). Micaschists have $\delta^{7} \mathrm{Li}$ values of $-1.7 \pm 0.7$ to $+0.2 \pm 0.4 \%$ ( $2 \sigma \mathrm{SE}$ ), consistent with the $\delta^{7} \mathrm{Li}$ values of subducted sediments (mean value: $+3.01 \%$, Chan et al. (2006); -2.3 to $+6.8 \%$, Penniston-Dorland et al., $2012 ;-6$ to $+14.5 \%$, Romer \& Meixner, 2014) and upper continental crust $(0 \pm 2 \%$; Teng et al., 2004).

Minerals 
The Li contents in the minerals from the lle de Groix (from this study and El Korh et al., 2009) are reported in Fig. 5 and Table 5. In blueschists and eclogites, main Li-hosting minerals are glaucophane (48-319 ppm), omphacite (27-145 ppm) and phengite (4.4-39 ppm). Retrograde barroisite and actinolite formed after glaucophane have lower Li contents of 3.19.6 ppm. Epidote, garnet and accessory titanite have Li abundances of $0.67-41,0.47-1.5$ and 1.3-17 ppm, respectively. In the retrograde greenschists, Li is mainly hosted by chlorite (13-182 ppm), phengite (5.8-46 ppm), and epidote (1.3-31 ppm) (see also El Korh et al., 2009). Retrograde albite also host significant amounts of Li (41-212 ppm). Values are consistent with the values reported by Marschall et al. (2006) for HP metamorphic rocks of the Greek island of Syros (Cyclades). In micaschists, main Li-hosting minerals are white micas (phengite + paragonite; 28-61 ppm) and retrograde chlorite (150-180 ppm). Accessory tourmaline (detrital) also contains high amounts of $\mathrm{Li}$ (19-47 ppm), while Li abundances are low in garnet, chloritoid, epidote, and accessory titanite and apatite $(<5$ ppm) (Fig. 5; Table 5).

These results point out the importance of glaucophane and omphacite for the $\mathrm{Li}$ budget and isotopic fractionation during prograde and HP-LT metamorphic stages. The Li isotopic composition of glaucophane and omphacite are scattered within each sample, and vary on average from one sample to the other (Fig. 7; Table 6).

Glaucophane in blueschists has positive mean $\delta^{7} \mathrm{Li}$ values of $+1.3 \pm 8.5$ and $+1.3 \pm$ 4.3\% (2б SD) (Fig. 7a; Table 6). However, $\delta^{7} \mathrm{Li}$ variations are observed within glaucophane grains. Glaucophane core parts have generally positive MORB-like $\delta^{7} \mathrm{Li}$ values $(+2.5 \pm 3.4$ to $+3.8 \pm 6.1 \%$; $2 \sigma \mathrm{SD})$, while the $\delta^{7} \mathrm{Li}$ values decrease rimwards up to negative values $(-2.6 \pm$ 4.9 to $-0.1 \pm 3.6 \%$; $2 \sigma \mathrm{SD}$ ) (Figs. $7 \mathrm{~b}$ and $\mathrm{c}$; Table 6 ). No core-to-rim zonation of Li abundances is observed in blueschist GR02. Blueschist GR25a shows a relatively good correlation between individual $\mathrm{Li}$ abundances and $\delta^{7} \mathrm{Li}$ values, suggesting kinetic diffusion of Li during glaucophane crystallisation.

In eclogites, glaucophane has negative mean $\delta^{7} \mathrm{Li}$ values of $-4.8 \pm 2.3$ to $-2.3 \pm 4.4 \%$ o

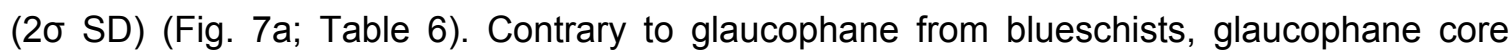


have negative $\delta^{7} \mathrm{Li}$ values. $\delta^{7} \mathrm{Li}$ values in glaucophane generally decrease from core $(-4.5 \pm$ 2.9 to $-1.1 \pm 3.4 \%$; $2 \sigma \mathrm{SD})$ to $\operatorname{rim}(-6.6 \pm 2.8$ to $-3.8 \pm 3.8 \%$; $2 \sigma \mathrm{SD})$. Lithium abundances do not vary from core to rim (Figs. $7 \mathrm{~d}-\mathrm{f}$; Table 6). The absence of core-to-rim zonation of Li abundances and the absence of correlation between the $\mathrm{Li}$ contents and $\mathrm{Li}$ isotopic compositions indicates that no late Li diffusion along grain boundaries occurred. Omphacite have negative mean $\delta^{7} \mathrm{Li}$ varying from $-15.6 \pm 9.4$ to $-3.5 \pm 5.2 \%$ ( $2 \sigma \mathrm{SD}$ ) (Fig. 7a; Table 6), contrasting with the positive $\delta^{7} \mathrm{Li}$ recorded by omphacite in the UHP eclogite from the Limousin ophiolite. No distinct rimward zonation of $\mathrm{Li}$ abundances and $\delta^{7} \mathrm{Li}$ values is observed (Fig. $7 d-f)$, excepting omphacite from eclogite GR24a, where $\delta^{7} \mathrm{Li}$ values lower than $-20 \%$ are measured in rim parts (Fig. 7e).

Despite the large $2 \sigma$ SD uncertainites of the mean $\delta^{7} \mathrm{Li}$ values obtained on the different phases, due to mineral heterogeneities and core-to-rim zonation, fractionation factors between glaucophane, omphacite and whole rock were calculated using these mean $\delta^{7} \mathrm{Li}$ values to determine if the main Li-hosting minerals show isotopic equilibrium with their respective whole rocks. Glaucophane is a major contributor for the whole rock isotopic

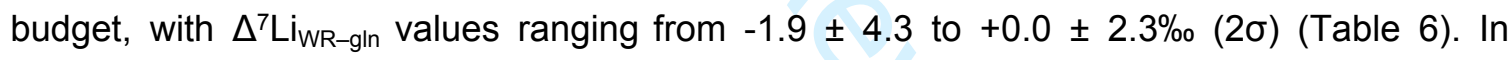
eclogites GR21 and 29 , omphacite display $\delta^{7} \mathrm{Li}$ values close to its host rock, with $\Delta^{7} \mathrm{Li}_{\text {WR-omph }}$ values varying between $-0.6 \pm 5.2$ and $-0.2 \pm 6.9 \%$ o $(2 \sigma)$, and with bulk glaucophane $\left[\Delta^{7} \mathrm{Li}_{\mathrm{gln}-}\right.$ omph values of $-0.2 \pm 7.3$ to $-0.1 \pm 8.3 \%$ ( $2 \sigma)]$ (Table 6 ), and thus can be considered at isotopic equilibrium, despite large uncertainties due to mineral heterogeneities. However, considering that omphacite have crystallised at the same time as glaucophane rims, the two minerals do not appear to be at isotopic equilibrium with $\Delta^{7} \mathrm{Li}_{\text {gln rim-omph }}$ values from $-3.1 \pm 5.9 \%$ o to $-0.5 \pm$ 5.9\%o $(2 \sigma)$, suggesting $\mathrm{Li}$ isotope fractionation under HP-LT conditions. At the opposite, omphacite from eclogite GR24a shows isotopic disequilibrium with whole rock and glaucophane, as evidenced by $\Delta^{7} \mathrm{Li}_{\text {WR-omph, }} \Delta^{7} \mathrm{Li}_{\text {gln-omph }}$ and $\Delta^{7} \mathrm{Li}_{\text {gln rim-omph }}$ values of $+13.1 \pm$ $9.4,+13.2 \pm 10.4 \%$ and $+11.7 \pm 8.3 \%$ o $(2 \sigma)$ (Table 6$)$. Retrograde barroisite formed along omphacite rims have mean $\delta^{7} \mathrm{Li}$ values within the same range as omphacite $(-15.4 \pm 18.2$ to - 
$5.6 \pm 6.5 \% ; 2 \sigma \mathrm{SD}$ ), but exhibits a large spread of $\delta^{7} \mathrm{Li}$ values, resulting in large $2 \sigma$ uncertainties on the $\Delta^{7} \mathrm{Li}_{\text {omph-barr }}$ values $[-0.1 \pm 20.5$ to $+1.0 \pm 9.5 \%$; $(2 \sigma)$; Table 6].

\section{CALCULATION OF THE FLUID Li ISOTOPIC COMPOSITION}

The fluid $\delta^{7} \mathrm{Li}_{\text {fluid }}$ composition is sensitive to temperature variations in the subduction zone (Marschall et al., 2007; Penniston-Dorland et al., 2012). Mineral-fluid fractionation factors obtained from experimental studies on Li fractionation between silicates (clinopyroxene: spodumene, staurolite, Li-amphibole and Li-mica) and $\mathrm{H}_{2} \mathrm{O}$ indicate that fluids generally display a higher $\delta^{7} \mathrm{Li}_{\text {fluid }}$ relative to rocks (Wunder et al., 2006, 2007, 2011). In our study, we have employed fractionation factors determined for clinopyroxene $\left(\Delta^{7} \mathrm{Li}_{\text {spudomene-fluid }}=-4.61 \times\right.$ $(1000 / T)+2.48$; Wunder et al., 2006), assuming a similar Li partition behaviour in clinopyroxene and amphiboles (inosilicates) relative to fluid (see also Penniston-Dorland et al., 2012). We have also employed the same fractionation factors to calculate the $\delta^{7} \mathrm{Li}_{\text {fluid }}$ of the fluid in equilibrium with the whole rocks from the lle de Groix. The $\delta^{7} \mathrm{Li}_{\text {fluid }}$ of the fluid in equilibrium with serpentine (phyllosilicate) was calculated using the fractionation factor determined for micas (phyllosilicates) $\left(\Delta^{7} \mathrm{Li}_{\text {mica-fluid }}=-4.52 \times(1000 / \mathrm{T})+4.74\right.$; Wunder et al., $2007,2010)$. However, the large range of temperature at which the different minerals were formed is a major source of uncertainty on the fluid isotopic composition.

\section{Limousin}

The temperature of hydrothermal of oceanic basalts and serpentine formation is rather poorly defined (Mével, 2003). Ocean-floor serpentinites in ophiolites commonly follow a retrograde reaction and often display the crystallisation sequence antigorite $>$ chrysotile $>$ lizardite with decreasing temperature (O'Hanley, 1996). Hydrothermal alteration of ultrabasic rocks is assumed to have occurred between 350 and $500^{\circ} \mathrm{C}$, because of the presence of tremolitic amphibole and absence of talc in the mineral assemblage (Berger et al., 2005). In serpentinite LAU2, $\delta^{7} \mathrm{Li}_{\text {fluid }}$ calculated for Mg-rich serpentine and altered Fe-richer serpentine 
yield undistinguishable negative values of -7.8 to $-6.4 \%$ and -7.6 to $-6.2 \%$, respectively, for temperatures decreasing from $500^{\circ} \mathrm{C}$ to $350^{\circ} \mathrm{C}$ (Fig. 8a; Table 7).

Formation of the second generation of serpentine in samples FLOT2a and CLUZ6, evidenced by a rimward increase in $\mathrm{MgO}$, may result from changes in hydrothermal alteration temperature conditions. This may correspond to the formation of different serpentine species: transition from antigorite to chrysotile/lizardite is typical of a temperature decrease during hydrothermal alteration (e.g. Evans et al., 1976; Mével, 2003; Wunder et al., 2010). XRD measurements in sample FLOT $2 \mathrm{~b}$ have shown that the three serpentine species are present. Variation in the Mg\# may also reflect the incorporation of various small-size minerals within serpentine layers (Viti \& Mellini, 1998; Früh-Green et al., 2004; Bach et al., 2006): Feoxides, hydroxides or clay minerals in equilibrium with the first generation of serpentine and Mg-hydroxides (brucite) in equilibrium with the second generation. Fe-rich serpentine in serpentinite CLUZ6 has totally replaced olivine, and yield a $\delta^{7} \mathrm{Li}_{\text {fluid }}$ value of -1.1 to $+0.4 \%$ for temperatures decreasing from $500^{\circ} \mathrm{C}$ to $350^{\circ} \mathrm{C}$. The $\delta^{7} \mathrm{Li}_{\text {fluid }}$ of the fluid in equilibrium with the Mg-richer serpentine (rimming the Fe-rich serpentine) and amphibole (tremolite to Mghornblende) have been estimated to be +5.3 to $+6.7 \%$ and $+10.1 \%$, respectively (Fig. $8 \mathrm{a}$; Table 7). A $\delta^{7} \mathrm{Li}_{\text {fluid }}$ value varying between -1.4 and $0.0 \%$ has been calculated for the $\mathrm{Mg}$-rich serpentine rimming olivine in the serpentinite FLOT2a, at a temperature decreasing from $500^{\circ} \mathrm{C}$ to $350^{\circ} \mathrm{C}$ (Table 7 ).

Based on thermometric calculations, Berger et al. (2005) have determined the temperature of equilibration of amphibole and plagioclase in amphibolites to vary between 572 and $749^{\circ} \mathrm{C}$. For this range of temperatures, the $\delta^{7} \mathrm{Li}_{\text {fluid }}$ of the fluid in equilibrium with hornblende in sample CLUZ1 varies from +5.5 to $+6.4 \%$ (Fig. $8 a$; Table 7 ). The altered zones in amphibole appear to have equilibrated with a heavy-Li fluid $\left(\delta^{7} \mathrm{Li}_{\text {fluid }}=+11.8\right.$ to $+12.7 \%$ ). Amphibolite CLUZ4 yields a high $\delta^{7} \mathrm{Li}_{\text {fluid }}$ value of +14.5 to $+15.5 \%$ (Table 7 ).

The UHP zoisite-eclogite L04-143 has recorded peak metamorphic P-T conditions of 3.0 GPa and $600^{\circ} \mathrm{C}$ (Berger et al., 2010a). The fluid in equilibrium with omphacite has a high $\delta^{7} \mathrm{Li}$ value of $+24.7 \%$ (Fig. $8 \mathrm{a}$; Table 7 ). Secondary pargasitic amphibole crystallisation 
occurred during partial retrogression of the rock (Berger et al., 2010a). A $\delta^{7} \mathrm{Li}_{\text {fluid }}$ was calculated to be $+21.5 \%$ at $600^{\circ} \mathrm{C}$ and $+22.1 \%$ at $500^{\circ} \mathrm{C}$.

\section{Ile de Groix}

The $\delta^{7} \mathrm{Li}$ of the fluid in equilibrium with the metabasites and blueschist-facies micaschists can be calculated using the peak metamorphic temperature conditions for blueschist and eclogite facies rocks $\left(500\right.$ and $550^{\circ} \mathrm{C}$, respectively; El Korh et al., 2009). In blueschists, the $\delta^{7} \mathrm{Li}$ of the fluid in equilibrium with the whole rocks have been calculated at $500^{\circ} \mathrm{C}$ to be +2.9 to $+4.2 \%$ o (Fig. 8b; Table 8). The detailed calculation of the $\delta^{7} \mathrm{Li}$ values of the fluid in equilibrium with glaucophane cores $\left(T \sim 450^{\circ} \mathrm{C}\right)$ and glaucophane rim $\left(T \sim 500^{\circ} \mathrm{C}\right)$ shows that the $\delta^{7} \mathrm{Li}$ values of the fluids decreased from $+6.4-7.7$ to $+0.9-3.4 \%$ with increasing temperature during glaucophane formation, i.e. during the prograde metamorphism. The $\delta^{7} \mathrm{Li}_{\text {fluid }}$ of the fluid in equilibrium with the blueschist-facies micaschists have been calculated to vary between +1.8 to $+3.7 \%$, at a temperature assumed to be $500^{\circ} \mathrm{C}$ (Table 8 ). These values are typical of subduction fluids with a mixed composition between altered oceanic crust and Global Subducting Sediment (GLOSS) $(+7 \pm 5 \%$; Simons et al., 2010$)$.

In eclogites, the $\delta^{7} \mathrm{Li}_{\text {fluid }}$ of fluids in equilibrium with whole rocks are -1.6 to $+0.7 \%$, indicating equilibrium with a fluid with a heavier $\mathrm{Li}$ isotopic composition than with blueschists (Fig. 8b; Table 8). The fluid in equilibrium with glaucophane cores $\left(T \sim 500^{\circ} \mathrm{C}\right)$ has $\delta^{7} \mathrm{Li}_{\text {fluid }}$ values of -1.1 to $+2.4 \%$. The $\delta^{7} \mathrm{Li}_{\text {fluid }}$ of fluids in equilibrium with glaucophane rims $\left(\delta^{7} \mathrm{Li}_{\text {fluid }}-\right.$ 3.5 to $-0.7 \%$ ) becomes Li-heavier with increasing temperature up to $550^{\circ} \mathrm{C}$. The $\delta^{7} \mathrm{Li}$ of fluids in equilibrium with omphacite vary between -1.4 and $-0.4 \%$ for eclogites GR21 and 29 (Fig. 8b; Table 8). Omphacite GR24a in eclogite yields a negative $\delta^{7} \mathrm{Li}_{\text {fluid }}$ of $-12.4 \%$, which is lower than that of whole rock $(-2.5 \%$; Table 4$)$, suggesting intensive fluid migration and metasomatism under HP conditions and quartz vein formation (El Korh et al., 2011; see also Fig. 2f).

Retrogression in the greenschist facies occurred under P-T conditions lower than 1.0 GPa and $450^{\circ} \mathrm{C}$ (El Korh et al., 2011, 2013). In greenschists, the $\delta^{7} \mathrm{Li}_{\text {fluid }}$ was calculated to be 
-0.6 to $+7.1 \%$ at a temperature of $450^{\circ} \mathrm{C}$ (Fig. $8 \mathrm{~b}$; Table 8 ). In the most retrogressed sample (albitic greenschist GROA52), the $\delta^{7} \mathrm{Li}_{\text {fluid }}$ was estimated to be $+5.8 \%$ at $400^{\circ} \mathrm{C}$. The results highlight heavy-Li fluid migration during retrogression.

\section{DISCUSSION}

Lithium behaviour and fractionation during hydrothermal alteration of the ocean crust: the case of Limousin ophiolite

The studied serpentinites from the Limousin ophiolite have low Li concentrations (0.9-4.6 ppm), as commonly observed for ocean floor serpentinites and serpentinised peridotites (Decitre et al., 2002; Scambelluri et al., 2004; Vils et al., 2008). In the studied serpentinites from Saint-Laurent (probably deriving from dunites), the Li content in serpentine increases in the Fe-rich serpentine generation, while the $\delta^{7} \mathrm{Li}$ values remain constant (c. $-8.9 \%$ ). Even if lithium in abyssal serpentinites is generally heavy with positive whole rock $\delta^{7} \mathrm{Li}$ values, serpentinised oceanic peridotites may display a large range of $\delta^{7} \mathrm{Li}$ values from -19 to $+28 \%$ o (Decitre et al., 2002; Benton et al., 2004). Serpentine formed early during hydrothermal alteration of oceanic peridotites preferentially incorporates ${ }^{6} \mathrm{Li}$ (Decitre et al., 2002). The low $\mathrm{Li}$ abundances in serpentinites and negative $\delta^{7} \mathrm{Li}$ values recorded by serpentine indicate that hydrothermal alteration occurred in equilibrium with a Li-poor fluid during the early stages of hydrothermal alteration, such as seawater or hydrothermal vent fluids (Chan et al., 1988). Hence, $\mathrm{Li}$ is leached from the basic oceanic crust by the passing fluid, resulting in a $\mathrm{Li}$ recycling during hydrothermal alteration of ultrabasic rocks (Decitre et al., 2002). At a constant temperature, Mg-rich serpentine and Fe-richer altered zones should have equilibrated with a fluid with a similar $\delta^{7} \mathrm{Li}$, varying from -7.6 to $-6.4 \%$ (Fig. 8a).

The studied serpentinites from La Flotte and Le Cluzeau (deriving from harzburgites or troctolites) have Li contents slightly lower than MORB suggesting only a minor Li loss during hydrothermal alteration. Lithium is mainly distributed between olivine, serpentine and amphibole (Fig. 3). During hydrothermal alteration, Li abundances slightly increase from olivine to the replacing Fe-rich serpentine and decrease in the Mg-rich serpentine generation, 
i.e. with decreasing temperature. The $\delta^{7} \mathrm{Li}$ values also vary during hydrothermal alteration. In serpentinite FLOT2a, the $\delta^{7} \mathrm{Li}$ values decreased from olivine relicts to Mg-rich serpentine from +6.3 to $-2.5 \%$ (Fig. $4 a$ ). In sample CLUZ6, the Fe-rich serpentine that has totally replaced olivine has a value similar to Mg-rich serpentine in sample FLOT2a (-2.16\%o). In sample CLUZ6, the $\delta^{7} \mathrm{Li}$ values increase in the second generation of serpentine (Mg-rich serpentine: $+4.2 \% 0$ ) and amphibole $(+6.6 \%)$, while the $\mathrm{Li}$ abundances decrease. Consequently, the chemistry of serpentine does not seem to be the only factor controlling $\mathrm{Li}$ fractionation.

The negative $\delta^{7} \mathrm{Li}$ recorded by serpentine formed after olivine indicates that hydrothermal alteration occurred in equilibrium with a fluid with a $\delta^{7} \mathrm{Li}_{\text {fluid }}$ value between -1.4 to $+0.4 \%$ at a temperature lower than $500^{\circ} \mathrm{C}$ (Fig. 8a). The low $\delta^{7} \mathrm{Li}$ of serpentine formed after olivine can be explained by fluid-induced kinetic fractionation during the early stage of hydrothermal alteration (Decitre et al., 2002). ${ }^{6} \mathrm{Li}$ is preferentially diffusing from the fluid phase to the rock during fluid-rock interactions due to its higher diffusivity compared to ${ }^{7} \mathrm{Li}$ (Richter et al., 2003). The higher $\delta^{7} \mathrm{Li}$ values and lower Li abundances recorded by the Mgrich serpentine and amphibole in sample CLUZ6 may reflect a change in the physicochemical conditions of fluid-rock interactions (e.g. fluid source, temperature, redox conditions). According to Decitre et al. (2002), the higher $\delta^{7} \mathrm{Li}$ values recorded by serpentine formed during a later stage of hydrothermal alteration reflect derivation from more evolved hydrothermal fluids, the latter becoming heavier during their passage through the oceanic crust.

In amphibolites from the Limousin ophiolite, hornblende is the main Li-bearing phase. Thus, its mean $\delta^{7} \mathrm{Li}$ value mirrors the whole rock $\delta^{7} \mathrm{Li}$ value. Hornblende display $\delta^{7} \mathrm{Li}$ values of +3.5 to $+12.5 \%$, typical of $\mathrm{Li}$ isotopic compositions of hydrothermally altered deep oceanic basic rocks (sheeted dykes and gabbros: -1.7 to $+7.9 \%$; Chan et al., 2002). Hornblende in the metamorphosed dyke CLUZ1 is isotopic lighter than in metagabbro CLUZ4. This result is in agreement with data obtained on the Troodos ophiolite (Cyprus), which show that the uppermost part of the altered oceanic crust is isotopically lighter than the deeper part, and 
probably reflect variable secondary mineral precipitation with depth during hydrothermal alteration (Coogan et al., 2017). The $\delta^{7} \mathrm{Li}_{\mathrm{f} \text { fluid }}$ values of the fluid in equilibrium with amphibolites range from +5.5 to $15.5 \%$, indicating interaction with heavy-Li fluids - seawater or upwelling hydrothermal fluids - under high-T to low-T hydrothermal conditions. Actually, samples that have incorporated a seawater $\mathrm{Li}$ component during low-T hydrothermal alteration have a $\delta^{7} \mathrm{Li}$ value of c. $+10 \pm 2 \%$ (Coogan et al., 2017). However, the MORB-like Li abundances in amphibolites (3.1-8.2 ppm) reflect limited fluid-rock interactions during hydrothermal alteration (Chan et al., 2002).

Even if serpentinites play a major role in fluid-mobile element recycling processes during subduction (Scambelluri et al., 2004; Kodolányi et al., 2012), our results support that abyssal serpentinites are not significant Li-carrier rocks in the subduction zone. Serpentinites dehydration would release $\mathrm{Li}$-poor fluids with variable $\delta^{7} \mathrm{Li}$, and does not constitute an important Li source for Li-rich HP-LT metamorphic rocks (see also Marschall et al., 2007; Halama et al., 2011). Dehydrating altered amphibolites would release Li-richer fluids with higher $\delta^{7} \mathrm{Li}$ than serpentinised rocks. Therefore, the high Li content in subducted metabasites can only be explained if a Li-rich sedimentary source is involved (Halama et al., 2011).

\section{Lithium fractionation during subduction zone metamorphism}

Early subduction hydrothermal processes in the samples from the lle de Groix

The high whole rock Li contents in the metabasic rocks of the lle de Groix (16-124 ppm) compared to fresh MORB (3-8 ppm; Niu \& Batiza, 1997) indicates that Li enrichment results from fluid overprint during pre-HP low-T hydrothermal processes. Lithium concentrations in the metabasites of the Ile de Groix are significantly higher than those of the Limousin ophiolite (altered oceanic crust) or altered MORB (ODP Sites 504B and 896A; 1-35 ppm; Chan et al., 2002) (Fig. 5). However, Li contents of metabasites are similar to those of altered oceanic crust in the Troodos ophiolite (Cyprus), which range from 3 to 119 ppm (Coogan et al., 2017). The uppermost part of the altered oceanic crust, i.e. the part in contact with the overlying sediments (mostly composed of limestones), shows the highest Li contents 
and ligher $\delta^{7} \mathrm{Li}$. The changes in $\mathrm{Li}$ compositions were interpreted as the result of changes in the secondary minerals with depth, rather than interaction with sediment-derived pore fluids (Coogan et al., 2017).

By contrast, the high Li abundances in the metabasites of the lle de Groix, as well as the large volume of metapelites in contact with the metabasites, would suggest a sedimentary source in addition to seawater for Li. Subducted sediments (such as the GLOSS) contain high amounts of Li (2-75 ppm; Bouman et al., 2004) and may release Lirich fluids in the subduction zone due to the prograde breakdown of Li-rich chlorite into garnet $+\mathrm{H}_{2} \mathrm{O}$ (Bebout et al, 2007; Halama et al., 2011). The high Li abundances measured in glaucophane indicates $\mathrm{Li}$ enrichment during the early stages of subduction, i.e. until the lawsonite-blueschist facies were reached at P-T conditions lower than 1.0-2.0 GPa and $350-450^{\circ} \mathrm{C}$ (El Korh et al., 2009). Contrary to the Fe isotope data from the same series of samples, which only show slight $\mathrm{Fe}$ isotope fractionation during low-temperature hydrothermal alteration (El Korh et al., 2017a), Li is strongly sensitive to hydrothermal processes. However, the Li compositions of the metabasites of the lle de Groix do not follow the common fractionation trend of low-temperature hydrothermal alteration observed in the altered oceanic crust (increase of Li contents and increase of the $\delta^{7} \mathrm{Li}$ value; e.g. Chan et al., 2002; Woodland et al., 2002).

Blueschist to eclogite facies metamorphism in the samples from the lle de Groix: effects of kinetic isotope fractionation

The $\delta^{7} \mathrm{Li}$ decrease from the blueschist to the eclogite facies metabasites of the lle de Groix do not correlate with the large range of $\mathrm{Li}$ abundances (Figs. 6a, and b), indicating that $\mathrm{Li}$ may have fractionated during the subduction zone metamorphism. Enrichment of Li coupled to a $\delta^{7} \mathrm{Li}$ decrease in orogenic eclogites and HP-LT rocks after the onset of subduction is a common feature (Zack et al., 2003; Marschall et al., 2006, 2007; Agostini et al., 2008; Penniston-Dorland et al., 2010, 2012; Simons et al., 2010; Halama et al., 2011; Xiao et al., 2011; Romer \& Meixner, 2014). The pioneering study of Zack et al. (2003) argued that light 
Li signatures of eclogites from Trescolmen (Adula nappe, Central Alps, Switzerland) do not originate from the surrounding metasediments, but follow a Rayleigh distillation during dehydration of clays and/or chlorite during the early stages of subduction zone metamorphism. However, based on experimental and natural data, Marschall et al., (2007) have shown that the high $\mathrm{Li}$ concentrations coupled to negative $\delta^{7} \mathrm{Li}$ values observed in most eclogites do not follow a Rayleigh dehydration process. Thus, $\mathrm{Li}$ isotope fractionation is the result of kinetic fractionation during eclogitisation and/or exhumation (Marschall et al., 2007; Halama et al., 2011). The changes in the Li isotope ratios in the subducted rocks is coupled to a significative mobilisation of $\mathrm{Li}$ during dehydration reactions, with a loss of 40 to $60 \%$ of the initial whole rock Li content (Marschall et al., 2007; Beinlich et al., 2010).

During dehydration reactions, the fluid regime and rock porosity evolves continuously. First, fluids migrate in small scale and form dehydration veins (= closed system; slow and low fluid fluxes). With increasing rock porosity during metamorphic reactions, the fluid regime evolves to channelised fluid flow (or transport veins; fast and high fluid fluxes) carrying externally derived fluids in open system on the outcrop scale (John et al., 2008; Taetz et al., 2018). The change in the fluid regime allows diffusive transport of Li from the unfractured rocks to the wall rock and vein, and thus kinetic isotope fractionation during fluid-induced eclogitisation (John et al., 2012; Jonas et al., 2014; Taetz et al., 2018).

Fluids released by dehydration processes of pelitic sediments and basic rocks of the Ile de Groix were channelised during the HP-LT event, as shown by the large vein network developed in the metamorphic rocks (El Korh et al., 2011). Fluid-rock interactions mainly involved internally-derived fluids, or fluids derived from the deeper part of the subducted crust and equilibrated with their host rocks. Most of the studied massive blueschists and eclogites do not crop in contact with large veins, and did not interact with the passing fluids owing to their low permeability and porosity (El Korh et al., 2011, 2013). Consequently, the whole rock $\delta^{7} \mathrm{Li}$ decrease from MORB-like values in blueschists to negative values in eclogites (Fig. 6a) during HP-LT metamorphism may be interpreted as the result of progressive fluid-induced $\mathrm{Li}$ kinetic diffusion and isotope fractionation during dehydration 
reactions already under prograde epidote-blueschist facies P-T conditions, without involving high fluid fluxes (Fig. 6a). The importance of the transition from blueschist facies to eclogite facies is also evidenced by the results of Halama et al. (2011), who showed that zoisiteeclogites from the Raspas Compex (Ecuador) experienced more intensive metasomatic effects than blueschists. Li diffusion on the intragrain scale and along grain boundaries is triggered by mineral appearance and disappearance related to metamorphic reactions and fluid-related dissolution-precipitation processes (Jonas et al., 2014; Taetz et al., 2018). In blueschists, the $\delta^{7} \mathrm{Li}$ decreases from MORB-like values in glaucophane core to negative values in rims (Figs. $7 b$ and $c$ ). Thus, the metabasites were able to conserve a MORB-like isotopic signature after the onset of subduction, i.e. until blueschist facies conditions were reached, even if Li was enriched during the pre-HP hydrothermal processes.

The metamorphic minerals (glaucophane and omphacite) carry high Li contents in the subduction zone, owing to their large stability field during the prograde metamorphism, from lawsonite-blueschist facies (1.0-2.0 GPa, $350-450^{\circ} \mathrm{C}$; El Korh et al., 2009) to eclogite facies P-T conditions (1.6-2.5 GPa, 500-600 $\mathrm{C}$; El Korh et al., 2009). The high Li content in glaucophane indicate that glaucophane is the main mineral controlling Li fractionation during prograde blueschist facies metamorphism up to HP-LT peak metamorphic conditions. Lithium isotope fractionation occurred during the prograde dehydration with increasing temperature conditions, probably at the transition from the lawsonite-blueschist facies (= glaucophane core crystallisation) to the epidote-garnet-blueschist facies (= glaucophane rim formation). The blueschists from the lle de Groix contain frequent lawsonite pseudomorphs. Lawsonite breakdown during prograde metamorphism produces large amounts of fluids, which may trigger fluid-induced Li kinetic diffusion and isotope fractionation already under lower grade conditions (transition from lawsonite-blueschist to epidote-blueschist facies). The decrease of the $\delta^{7} \mathrm{Li}$ values may be associated to Li enrichment in glaucophane rims (sample GR25a; Fig. 7c) during metasomatic processes.

Omphacite and glaucophane in eclogites have lower $\delta^{7} \mathrm{Li}$ values than MORB. The rimward $\delta^{7} \mathrm{Li}$ decrease in glaucophane indicates that fluid-induced kinetic Li diffusion still 
went on during eclogitisation (Figs. $7 \mathrm{~d}-\mathrm{f}$ ). As observed for blueschists, the $\Delta^{7} \mathrm{Li}_{\mathrm{WR}-\mathrm{gln}}, \Delta^{7} \mathrm{Li}_{\mathrm{WR}-}$ omph values and $\Delta^{7} \mathrm{Li}_{\mathrm{g} \mid \mathrm{n}-\mathrm{omph}}$ of $-0.6 \pm 5.2$ to $0.0 \pm 2.3 \%$ in eclogites $\mathrm{GR} 21$ and 29 indicate that bulk glaucophane and bulk omphacite are relatively at isotopic equilibrium with their host rock. However, the negative $\Delta^{7} \mathrm{Li}_{\mathrm{gln}}$ rim-omph values from $-3.1 \pm 5.9$ to $-0.5 \pm 5.9$ reveal $\mathrm{Li}$ isotope fractionation under peak metamorphic $\mathrm{P}-\mathrm{T}$ conditions. For only one sample (eclogite GR24a), omphacite has a low $\delta^{7} \mathrm{Li}$ compared to the whole rock and glaucophane, resulting from metasomatic processes under eclogite facies $\mathrm{P}-\mathrm{T}$ conditions, as suggested by the presence of HP quartz veins (El Korh et al., 2011). Retrograde barroisite formed along omphacite rims have a mean $\delta^{7} \mathrm{Li}$ value similar to that of omphacite, but exhibits a large spread of $\delta^{7} \mathrm{Li}$ values, suggesting localised $\mathrm{Li}$ mobilisation and isotope fractionation during early retrogression. The calculated mean $\delta^{7} \mathrm{Li}_{\text {fluid }}$ of fluids in equilibrium with dehydrating metabasic and metapelitic rocks decrease from +8 to $-2 \%$ with increasing P-T conditions, i.e. from the lawsonite-blueschist facies $\left(1.0-2.0 \mathrm{GPa}, 350-450^{\circ} \mathrm{C}\right)$ to the eclogite facies $\left(1.6-2.5 \mathrm{GPa}, 500-600^{\circ} \mathrm{C}\right)$ (Fig. $8 \mathrm{~b}$ ), even if the $\delta^{7} \mathrm{Li}_{\text {fluid }}$ values remain higher than the corresponding $\delta^{7} \mathrm{Li}_{\text {solid }}$ (see also Marschall et al., 2007; Penniston-Dorland et al., 2012). Consequently, our study argues that the $\delta^{7} \mathrm{Li}$ decrease during subduction zone prograde metamorphism results from cumulative effects of dehydration and fluid-induced Li kinetic diffusion and isotope fractionation.

Our data agree with the $\delta^{7} \mathrm{Li}_{\text {fluid }}$ decrease in dehydrating metasediments of high metamorphic grade (lawsonite-blueschist and epidote-amphibolite facies; $275-750^{\circ} \mathrm{C} ; 0.5-$ 1.2 GPa; Bebout \& Barton, 1993) from the Catalina Schist (Penniston-Dorland et al., 2012). The highest $\delta^{7} \mathrm{Li}_{\text {fluid }}(+6.4$ to $+7.7 \%$; Fig. $8 \mathrm{~b})$ at equilibrium with glaucophane cores in blueschists (lawsonite-blueschist facies) plot within the field of the $\delta^{7} \mathrm{Li}_{\text {fluid }}$ recorded by lawsonite-blueschist and amphibolite facies metabasites from the Catalina Schist (+7 to $+13 \%$; Penniston-Dorland et al., 2012). However, the $\delta^{7} \mathrm{Li}_{\text {fluid }}$ of fluids in equilibrium with the metabasites and metapelites of the Ile de Groix of higher metamorphic grade (epidoteblueschist to eclogite facies; $\delta^{7} \mathrm{Li}_{\text {fluid }}$ of -3.5 to $+4.2 \%$; Fig. $8 \mathrm{~b}$ ) are generally lower than the $\delta^{7} \mathrm{Li}_{\text {fluid }}$ of the fluids derived from the metasedimentary and metabasic rocks of the Catalina 
Schist (c. $+5-18 \%$; Penniston-Dorland et al., 2012), but plot within the field of kinetically altered amphibolites (0 to $+4 \%$; Penniston-Dorland et al., 2012). The heavy-Li fluids in equilibrium with blueschist-facies metabasites and micaschists are typical of subduction fluids with a mixed composition between altered oceanic crust and GLOSS (+7 $\pm 5 \%$; Simons et al., 2010). The release of these fluids will result in a decrease of the ${ }^{7} \mathrm{Li}_{\text {solid, }}$ and could be at the origin of the low $\delta^{7}$ Li values of eclogites and fluids at equilibrium with them.

Fluids in equilibrium with eclogites have a lower $\delta^{7} \mathrm{Li}_{\text {fluid }}$ than subduction zone fluids. It is suggested that the low $\delta^{7} \mathrm{Li}_{\mathrm{i} f \text { luid }}$ under eclogite facies conditions may not reflect their real $\delta^{7} \mathrm{Li}_{\mathrm{i} l u i d}$ value, and would result from kinetic isotope fractionation that becomes predominant over equilibrium fractionation with increasing metamorphic grade and temperature (Richter et al., 2003; Marschall et al., 2007).

Li isotope fractionation during greenschist facies retrograde metamorphism related to exhumation of the lle de Groix

During exhumation of the rocks from the lle de Groix, the degree of retrogression of metabasites is directly related to the free fluid phase, i.e. to the porosity. During the early stages of exhumation ( $<1.6 \mathrm{GPa}, 450-500^{\circ} \mathrm{C}$; El Korh et al., 2009), retrograde reactions occured under restricted fluid-rock interactions and involved internally-derived fluids (EI Korh et al., 2013). The similar Li abundances and $\delta^{7} \mathrm{Li}$ values of blueschists and eclogites $(-4.8$ to $+0.7 \%$ ) and greenschists $(-4.5$ to $-0.1 \%$ ) that underwent restricted fluid-rock interactions during retrogression ( $\delta^{7} \mathrm{Li}_{\text {fluid }}$ of -0.6 and $+3.8 \%$ for samples GR23 and $25 \mathrm{~b}$, respectively; Fig. $8 b)$, indicate that fluid-induced metasomatism was not able to reset the $\mathrm{Li}$ isotope distribution. During the advanced stages of retrogression, the permeability and porosity of the metabasites increase with the decrease of the P-T conditions $\left(<1.0 \mathrm{GPa},<400-450^{\circ} \mathrm{C}\right)$, allowing migration of higher amounts of fluids derived from the dehydrated metabasites (EI Korh et al., 2011, 2013). The increase of the $\delta^{7} \mathrm{Li}$ values toward positive values in the most retrogressed samples $(+3.2$ and $+1.5 \%$ for samples GR06a and GROA52, respectively) highlights a $\mathrm{Li}$ mineral/fluid isotopic exchange and migration of fluids with a heavier- $\mathrm{Li}$ 
composition $(+5.8$ to $+7.6 \%$; Fig. $8 b)$ during rehydration reactions. Our results agree with Penniston-Dorland et al. (2010), who observed retrograde reactions related to an infiltration of an aqueous fluid with high $\delta^{7} \mathrm{Li}_{\text {fluid }}$ in HP rocks from the Franciscan Complex (California, USA). Similarly, Xiao et al. (2011) observed heavier Li isotopic compositions in retrograde amphibolites $(-0.4 \pm 0.3$ to $+0.9 \pm 0.2 \%$ ) compared to neighbouring UHP eclogites $(-6.9 \pm 0.2$ to $-6.5 \pm 0.1 \%$ ) from the Chinese Continental Scientific Drilling Program (Sulu, East China). The authors suggest that $\mathrm{Li}$ budget and isotope fractionation is mostly controlled by the mineral assemblage, as significant fractionation occur both in closed and open fluid-rock systems (Xiao et al., 2011).

Our data confirm that $\mathrm{Li}$ isotopes are strongly sensitive to retrograde fluid-rock interactions related to exhumation of HP rocks. Significant $\mathrm{Li}$ isotope fractionation during rehydration reactions in open system result in apparent Li compositions that do not reflect the subduction signature anymore. A similar behaviour has also been reported for $\mathrm{Ge}$ isotopes (El Korh et al., 2017b): rehydration reactions triggered Ge isotope fractionation towards heavier compositions in the most retrogressed greenschists, while the least retrogressed samples (closed system) can retain the Ge isotope signature of high grade facies metabasites.

\section{Li isotope fractionation in the Limousin UHP zoisite-eclogite}

The Li abundances and isotopic data in the UHP zoisite-eclogite from the Limousin significantly contrast with the results obtained for the lle de Groix. The UHP zoisite eclogite, deriving from an iron-rich plagioclase cumulate such as those emplaced in continental intrusions or forming Fe-Ti oceanic gabbros (Berger et al., 2010a), has a $\mathrm{Li}$ abundance slightly lower than MORB (Fig. 3). Garnet and zoisite are the most abundant minerals, but do not play an important role in the Li budget due to their low Li contents (Fig. 3). Omphacite and pargasitic amphibole are the main hosts for $\mathrm{Li}$, but display lower $\mathrm{Li}$ contents than in eclogites from the Ile de Groix. However, they show a heavy-Li signature typical of lowtemperature altered oceanic crust (Chan et al., 2002), with $\delta^{7} \mathrm{Li}$ values considerably higher 
than those of the lle de Groix (Figs. 4 and 6).

The positive $\delta^{7} \mathrm{Li}$ value recorded by omphacite agrees with the model of $\mathrm{Li}$ fractionation determined by Marschall et al (2007) predicting that deeply subducted eclogites have a heavier Li signature than the mantle. However, the abnormally high $\delta^{7} \mathrm{Li}$ recorded by omphacite probably reflects an interaction with a heavy-Li fluid migrating in the subduction zone (Fig. 8a). Zoisite-eclogites have been intensively metasomatised during the UHP event, by interaction with a fluid derived from dehydrating subducted sediments at the interface slab/mantle (Berger et al., 2010a). Extremely heavy-Li isotopic signatures related to high $\mathrm{Li}$ mobility are characteristic of upwelling fluids and sediments in subduction zone decollements (Chan \& Kastner, 2000). However, the low Li abundances do not argue for any Li transport and enrichment from the fluid phase, but may reflect Li leaching and preferential ${ }^{6} \mathrm{Li}$ transfer towards the passing fluid. The decrease of the $\delta^{7} \mathrm{Li}$ value in secondary pargasitic amphibole (from $+21.9 \%$ in omphacite to $+18.7 \%$ in amphibole) indicates interaction with a Li-richer and lighter fluid during partial retrogression (Figs. $4 \mathrm{~b}$ and $8 \mathrm{a}$ ).

Muscovite and quartz in pegmatites from Black Hills (South Dakota, USA) also exhibit heavy- $\mathrm{Li}$ isotopic signatures (up to $+21.3 \%$ ) and result from crystal melt fractionation (Teng et al., 2006). The high $\delta^{7} \mathrm{Li}$ values in omphacite from the UHP zoisite-eclogite may also reflect interaction with crustal-derived fluids during subduction or, more unlikely a crustal contamination during differentiation of the magmatic protolith (see Berger et al., 2010a for discussion of the protolith origin). In any case, the zoisite-eclogite L04-143 derives from a protolith of a different composition than the MORB-derived rocks of the lle de Groix, and have undegone a different metamorphic history during subduction.

\section{SYNTHESIS AND CONCLUSIONS}

This study provides bulk and in-situ analyses to reconstruct Li behaviour and isotope fractionation during the various stages of fluid-rock interactions occurring in the ancient Variscan oceanic lithosphere, including seafloor high-T and low-T hydrothermal alteration, subduction and exhumation processes. 
1) In the Limousin ophiolite, high-T hydrothermal alteration of ultrabasic rocks produces serpentinites with a Li concentration lower than $5 \mathrm{ppm}$ during interaction with hydrothermal fluids and/or seawater. Serpentine formed during the early stages of alteration has a low $\delta^{7} \mathrm{Li}$. The $\delta^{7} \mathrm{Li}$ increase in serpentine formed during the late stages of hydrothermal alteration indicates changes in the fluid $\delta^{7} \mathrm{Li}_{\text {fluid }}$ composition and, probably, a temperature decrease from high-T to low-T conditions. Amphibolites display Li contents and isotopic compositions typical of hydrothermally altered sheeted dykes and gabbros. The high $\delta^{7} \mathrm{Li}$ values of amphibolites indicate an interaction with heavy-Li fluids - seawater or upwelling hydrothermal fluids - under high-T conditions. These results confirm that Li-poor abyssal serpentinites do not constitute an important source of Li for Li-rich metabasic rocks during subduction zone metamorphism.

2) Li concentrations in the metabasites of the lle de Groix are significantly higher than in fresh MORB. The elevated Li content in the subducted metabasites of the lle de Groix can only be explained by a metasomatic overprint of fluids derived from Li-rich sediments during the early stages of subduction, as observed in other orogenic eclogites. Lithium abundances remain high in the metabasites of the lle de Groix during subduction zone metamorphism, owing to the large stability field of Li-hosting minerals from the lawsonite-blueschist to the eclogite facies, and in retrograde greenschist facies rocks. Lithium is mainly hosted by 1) glaucophane and omphacite in blueschists and eclogites; 2) chlorite and albite in retrograde greenschists; 3) phengite and chlorite in micaschists.

3) The metabasites of the lle de Groix have whole rock $\delta^{7} \mathrm{Li}$ values decreasing from blueschists to eclogites. Both bulk and in-situ $\delta^{7} \mathrm{Li}$ data clearly demonstrate that $\mathrm{Li}$ isotopes fractionate under blueschist facies conditions in metabasic rocks, i.e. before eclogite facies conditions are reached in the subduction zone. Glaucophane in blueschists have $\delta^{7} \mathrm{Li}$ values decreasing rimwards from positive $\delta^{7} \mathrm{Li}$ values to negative values, indicating that significant $\mathrm{Li}$ 
isotope fractionation in the metabasites of the lle de Groix occurred at the transition from the lawsonite-blueschist facies to the epidote-garnet-blueschist facies. Lawsonite breakdown releases high amounts of fluids, which can trigger fluid-induced kinetic fractionation of Li. In the eclogites facies metabasites from the lle de Groix, omphacite and glaucophane have lower $\delta^{7} \mathrm{Li}$ values than glaucophane in blueschists, indicating that fluid-induced kinetic $\mathrm{Li}$ diffusion carried on during eclogitisation. However the calculated ${ }^{7} \mathrm{Li}_{\text {fluid }}$ at equilibrium may be not representative, because of the possible predominance of kinetic isotope fractionation compared to equilibrium fractionation.

Calculation of the fluid $\delta^{7} \mathrm{Li}$ values in equilibrium with the metabasites and metapelites of the lle de Groix reveals that the dehydrating metabasites release heavy-Li fluids typical of subduction fluids. The fluid $\delta^{7} \mathrm{Li}$ values in equilibrium with metabasites decrease with increasing metamorphic grade up to eclogite facies conditions. Overprint of a fluid under HP conditions with an extremely low $\delta^{7} \mathrm{Li}$ value is evidenced by omphacite in one eclogite sample. However, the $\delta^{7} \mathrm{Li}$ of fluids under epidote-blueschist and eclogite facies may not be representative of the real composition because of the predominance of kinetic isotope fractionation compared to equilibrium fractionation with increasing temperature conditions.

4) The low $\mathrm{Li}$ abundances and high $\delta^{7} \mathrm{Li}$ values recorded by omphacite and pargasitic amphibole in the UHP zoisite-eclogite from the Limousin significantly contrast with the results obtained for the Ile de Groix. This probably reflects Li leaching and Li isotopic fractionation during intensive metasomatism by a fluid derived from dehydrating sediments. It may also reflect crustal contamination in the protolith composition.

5) Retrograde greenschists from the lle de Groix have whole rock Li abundance and $\delta^{7} \mathrm{Li}$ values within the same range as blueschists and eclogites. Therefore, the increase of the $\delta^{7} \mathrm{Li}$ values toward positive values in the most retrogressed samples highlight a $\mathrm{Li}$ mineral/fluid isotopic exchange during rehydration reactions and interaction with a Li-heavy fluid. 
6) Lithium isotope fractionation in blueschists and in the most retrogressed greenschists from the Ile de Groix highlights the migration of heavy-Li fluids along the oceanic crust-mantle interface in the subduction zone. As predicted by former models of Li fractionation in subduction zones (Elliott et al., 2004, 2006; Marschall et al., 2007; Halama et al., 2011), our data suggest that migration of heavy-Li fluids along the crust-mantle wedge may be responsible for an enrichment of the fore-arc mantle wedge along the subduction channel.

\section{ACKNOWLEDGMENTS}

Thanks to Chantal Peiffert for technical assistance in the LA-ICPMS laboratory, to the team of the SARM-chimie (SARM, CRPG, Nancy) for whole rock Li analyses. Aimeryc Schumacher is acknowledged for his help with the MC-ICPMS analyses. We also thank Nordine Bouden, Andrey Gurenko and Denis Mangin for technical assistance during SIMS analyses, and Olivier Rouer for help in the microprobe laboratory. Bernard Grobéty is thanked for his help with XRD analyses. Jürgen von Raumer is thanked for fruitful discussions on the Variscan palaeogeography. We thank Julien Berger for sending UHP zoisite-eclogite sample L04-143. This study benefited from detailed reviews of four anonymous reviewers. We also thank Simon Turner for the editorial handling of our manuscript. The research was supported by project P300P2_147749 of the Swiss National Science Foundation, and benefited from a funding from the Observatoire de la Terre et de I'Environnement en Lorraine (OTELO-CNRS). This work has also been supported by the French National Research Agency through the national program "Investissements d'avenir" (ANR-10-LABX-21-LABEX RESSOURCES21). This is a CRPG-CNRS contribution n 2701.

\section{REFERENCES}

Agostini, S., Ryan, J. G., Tonarini, S. \& Innocenti, F. (2008). Drying and dying of a subducted slab: coupled Li and B isotope variations in Western Anatolia Cenozoic Volcanism. Earth and Planetary Science Letters 272, 139-147. 
Audren, C., Triboulet, C., Chauris, L., Lefort, J.-P., Vigneresse, J.-L., Audrain, J., Thiéblemont, D., Goyallon, J., Jégouzo, P., Guennoc, P., Augris, C. \& Carn, A. (1993). Notice explicative de la feuille lle de Groix à 1/25000, carte géologique. BRGM, Orléans. Bach, W., Paulick, H., Garrido, C. J., Ildefonse, B., Meurer, W. P. \& Humphris, S. E. (2006). Unraveling the sequence of serpentinization reactions: petrography, mineral chemistry, and petrophysics of serpentinites from MAR $15^{\circ} \mathrm{N}$ (ODP Leg 209, Site 1274). Geophysical Research Letters 33, L13306, doi:10.1029/2006GL025681.

Ballèvre, M., Martínez Catalán, J.R., López-Carmona, A., Pitra, P., Abati, J., Díez Fernández, R., Ducassou, C., Arenas, R., Bosse, V., Castiñeiras, P., Fernández-Suárez, J., Gómez Barreiro, J., Paquette, J.-L., Peucat, J.-J., Poujol, M., Ruffet, G. \& Sánchez Martínez, S. (2014). Correlation of the nappe stack in the Ibero-Armorican arc across the Bay of Biscay: a joint French-Spanish project. In: Schulmann, K., Martínez Catalán, J. R., Lardeaux, J. M., Janousek, V., Oggiano, G. (eds), "The Variscan orogeny: extent, timescale and the formation of the European crust". Geological Society of London Special Publications 405, 77-113.

Ballèvre, M., Pitra, P. \& Bohn, M. (2003). Lawsonite growth in the epidote blueschists from the Ile de Groix (Armorican massif, France): a potential geobarometer. Journal of Metamorphic Geology 21, 723-735.

Barrientos, X. \& Selverstone, J. (1993). Infiltration vs. thermal overprinting of epidote blueschists, lle de Groix, France. Geology 21, 69-72.

Bebout, G. E. \& Barton, M. D. (1993). Metasomatism during subduction: products and possible paths in the Catalina Schist, California. Chemical Geology 108, 61-92.

Bebout G. E., Bebout A. E. \& Graham C. M. (2007). Cycling of B, Li, and LILE (K, Cs, Rb, $\mathrm{Ba}, \mathrm{Sr}$ ) into subduction zones: SIMS evidence from micas in high-P/T metasedimentary rocks. Chemical Geology 239, 284-304.

Bebout, G. E., Ryan, J. \& Leeman, W. (1993). B-Be systematics in subduction-related metamorphic rocks: Characterization of the subducted component. Geochimica et Cosmochimica Acta 57, 2227-2237. 
Bellot, J. P. \& Roig, J. Y. (2007). Episodic exhumation of HP rocks inferred from structural data and P-T paths from the Southwestern Massif Central (Variscan belt, France). Journal of Structural Geology 29, 1538-1557.

Benton, L. D., Ryan, J. G. \& Savov, I. P. (2004). Lithium abundance and isotope systematics of forearc serpentinites, Conical Seamount, Mariana forearc: Insights into the mechanics of slab-mantle exchange during subduction, Geochemistry Geophysics Geosystems 5, Q08J12, doi:10.1029/2004GC000708.

Berger, J., Féménias, O., Mercier, J. C. C. \& Demaiffe, D. (2005). Ocean-floor hydrothermal metamorphism in the Limousin ophiolites (western French Massif Central): evidence of a rare preserved Variscan oceanic marker. Journal of Metamorphic Geology 23, 795-812.

Berger, J., Féménias, O., Mercier, J. C. C. \& Demaiffe, D. (2006). A Variscan slow-spreading ridge (MOR-LHOT) in Limousin (French Massif Central): magmatic evolution and tectonic setting inferred from mineral chemistry. Mineralogical Magazine 70, 175-185.

Berger, J., Féménias, O., Ohnenstetter, D., Bruguier, O., Plissart, G., Mercier, J. C. C. \& Demaiffe, D. (2010a). New occurrence of UHP eclogites in Limousin (French Massif Central): Age, tectonic setting and fluid-rock interactions. Lithos 118, 365-382.

Berger, J., Féménias, O., Ohnenstetter, D., Plissart, G. \& Mercier, J. C. C. (2010b). Origin and tectonic significance of corundum-kyanite-sapphirine amphibolites from the Variscan French Massif Central. Journal of Metamorphic Geology 28, 341-360.

Bernard-Griffiths, J., Carpenter, M. S. N., Peucat, J.-J. \& Jahn, B. M. (1986). Geochemical and isotopic characteristics of blueschist facies rocks from the lle de Groix, Armorican Massif (northwest France). Lithos 19, 235-253.

Berthelsen, A. (1992). Mobile Europe. In Blundell, D., Freeman, R. \& Mueller, S. (eds) A continent revealed. The European geotraverse, Cambridge University Press, Cambridge, UK, 11-32.

Bosse, V., Ballèvre, M. \& Vidal, O. (2002). Ductile thrusting recorded by the garnet isograd from blueschist-facies metapelites of the Ile de Groix, Armorican Massif, France. Journal of Petrology 43, 485-510. 
Bosse, V., Féraud, G., Ballèvre, M., Peucat, J.-J. \& Corsini, M. (2005). Rb-Sr and 40Ar/39Ar ages in blueschists from the lle de Groix (Armorican Massif, France): Implications for closure mechanisms in isotopic systems. Chemical Geology 220, 21-45.

Bouman, C., Elliott, T. \& Vroon, P. Z. (2004). Lithium inputs to subduction zones. Chemical Geology 212, 59-79.

Bouvier, A.-S., Métrich, N. \& Deloule, E. (2008). Slab-derived fluids in magma sources of St. Vincent (Lesser Antilles Arc): Volatile and light element imprints. Journal of Petrology 49, $1427-1448$.

Brenan, J. M., Ryerson, F. J. \& Shaw, H. F. (1998). The role of aqueous fluids in the slab-tomantle transfer of boron, beryllium, and lithium during subduction: Experiments and models. Geochimica et Cosmochimca Acta 62, 3337-3347.

Carignan, J., Hild, P., Mevelle, G., Morel, J. \& Yeghicheyan, D. (2001). Routine analyses of trace elements in geological samples using flow injection and low pressure on-line liquid chromatography coupled to ICP-MS: A study of geochemical reference materials BR, DRN, UB-N, AN-G and GH. Geostandard Newsletters 25, 187-198.

Carpenter, M. S. N. (1976). Petrogenetic study of the glaucophane schists and associated rocks from the Ile de Groix, Brittany, France. Unpublished PhD Thesis, Oxford University, $271 \mathrm{pp}$.

Chan, L. H., Alt, J. C. \& Teagle, D. A. H. (2002). Lithium and lithium isotope profiles through the upper oceanic crust: a study of seawater-basalt exchange at ODP sites 504b and 896a. Earth and Planetary Science Letters 201, 187-201.

Chan, L. H. \& Edmond, J. M. (1988). Variation of lithium isotope composition in the marine environment: A preliminary report, Geochimica et Cosmochimica Acta 52, 1711-1717.

Chan, L. H. \& Kastner, M. (2000). Lithium isotopic compositions of pore fluids and sediments in the Costa Rica subduction zone: implications for fluid processes and sediment contribution to the arc volcanoes. Earth and Planetary Science Letters 183, 275-290.

Chan, L. H., Leeman, W. P. \& Plank, T. (2006). Lithium isotopic composition of marine sediments. Geochemistry Geophysics Geosystems 7, Q06005. 
Chan, L. H., Leeman, W. P. \& You, C. F. (1999). Lithium isotopic composition of central American volcanic arc lavas: implications for modification of subarc mantle by slabderived fluids. Chemical Geology 160, 255-280.

Coogan, L. A., Gillis, K. M., Pope, M. \& Spence, J. (2017). The role of low-temperature (offaxis) alteration of the oceanic crust in the global Li-cycle: Insights from the Troodos ophiolite. Geochimica et Cosmochimica Acta 203, 201-215.

Decitre, S. E., Deloule, E., Reisberg, L., James, R., Agrinier, P. \& Mevel, C. (2002). Behavior of $\mathrm{Li}$ and its isotopes during serpentinization of oceanic peridotites. Geochemistry Geophysics Geosystems 3, doi.org/10.1029/2001GC000178.

Demange, M. (1994). Antevariscan evolution of the Montagne Noire (France): from a passive margin to a foreland basin. Comptes Rendus de l'Académie des Sciences de Paris $\mathbf{3 1 8}$ (II), 921-933.

Dubuisson, G., Mercier, J.-C. C., Girardeau, J. \& Frison, J.Y. (1989). Evidence for a lost ocean in Variscan terranes of the Western Massif Central, France. Nature 337, 729-732.

El Korh, A. (2010). Geochemical fingerprints of devolatilisation reactions in the high-pressure rocks of lle de Groix, France. PhD thesis, University of Geneva, Terre et Environnement 99, $361 \mathrm{pp}$.

El Korh, A., Luais, B., Boiron, M.-C., Deloule, E. \& Cividini, D. (2017b). Investigation of Ge and $\mathrm{Ga}$ exchange behaviour and $\mathrm{Ge}$ isotopic fractionation during subduction zone metamorphism. Chemical Geology 449, 165-181.

El Korh, A., Luais, B., Deloule, E. \& Cividini, D. (2017a). Iron isotope fractionation in subduction-related high-pressure metabasites (Ile de Groix, France). Contributions to Mineralogy and Petrology 172, 41.

El Korh, A., Schmidt, S. Th., Ballèvre, M., Ulianov, A. \& Bruguier, O. (2012). Discovery of an albite gneiss from the Ile de Groix (Armorican Massif, France): geochemistry and LA-ICPMS U-Pb geochronology of its Ordovician protolith. International Journal of Earth Sciences 101, 1169-1190. 
El Korh, A., Schmidt S. Th., Ulianov, A. \& Potel, S. (2009). Trace element partitioning in HP_ LT metamorphic assemblages during subduction-related metamorphism, lle de Groix, France: a detailed LA-ICP-MS study. Journal of Petrology 50, 1107-1148.

El Korh, A., Schmidt, S. Th., Vennemann, T. \& Ballèvre, M. (2013). Trace element and isotopic fingerprints in HP-LT metamorphic rocks as a result of fluid-rock interactions (lle de Groix, France). Gondwana Research 23, 880-900.

El Korh, A., Schmidt, S. Th., Vennemann, T. \& Ulianov, A. (2011). Trace element and Oisotope composition of polyphase metamorphic veins of the lle de Groix (Armorican Massif, France): implication for fluid flow during HP subduction and exhumation processes. In: Dobrzhinetskaya, L., Faryad, W., Wallis, S., Cuthbert, S. (eds), "Ultrahigh Pressure Metamorphism: 25 years after discovery of coesite and diamond". Elsevier, Amsterdam, Netherlands, 243-291.

Elliott, T., Jeffcoate, A. \& Bouman, C. (2004). The terrestrial Li isotope cycle: light-weight constraints on mantle convection. Earth and Planetary Science Letters 220, 231-245.

Elliott, T., Thomas, A., Jeffcoate, A. \& Niu, Y. (2006). Lithium isotope evidence for subduction-enriched mantle in the source of mid-ocean-ridge basalts. Nature $443,565-$ 568.

Evans, B. W., Johannes, W., Otterdoom, H. \& Trommsdorff, V. (1976). Stability of chrysotile and antigorite in the serpentine multi-system, Schweizerische Mineralogische Petrographische Mitteilungen 50, 481-492.

Faure, M., Lardeaux, J. M. \& Ledru, P. (2009). A review of the pre-Permian geology of the Variscan French Massif Central. Comptes Rendus Geosciences 341, 202-213.

Franke, W. (1992). Phanerozoic structures and events in Central Europe. In Blundell, D., Freeman, R. \& Mueller, S. (eds) A continent revealed. The European geotraverse, Cambridge University Press, Cambridge, UK, 164-180.

Früh-Green, G. L., Connolly, J. A. D., Plas, A., Kelley, D. S. \& Grobéty, B. (2004). Serpentinization of oceanic peridotites: Implications for geochemical cycles and biological Activity. In: Wilcock, W. S. D., Delong, E. F., Kelley, D. S., Baross, J. A., \& Craig Cary, S. 
(eds) The Subseafloor Biosphere at Mid-Ocean Ridges, American Geophysical Union, Washington, D. C.

Gao, Y., Snow, J. E., Casey, J. F. \& Yu, J. (2011). Cooling-induced fractionation of mantle Li isotopes from the ultraslow-spreading Gakkel Ridge. Earth and Planetary Science Letters, $301,231-240$.

Girardeau, J., Dubuisson, G. \& Mercier, J.-C. C. (1986). Cinématique de mise en place des ophiolites et nappes crystallophiliennes du Limousin, Ouest du Massif Central français. Bulletin de la Société Géologique de France 2, 849-860.

Halama, R., John, T., Harms, P., Hauff, F. \& Schenk, V. (2011). A stable (Li, O) and radiogenic $(\mathrm{Sr}, \mathrm{Nd})$ isotope perspective on metasomatic processes in a subducting slab. Chemical Geology 281, 151-166.

James, R. H. \& Palmer, M. R. (2000). The lithium isotope composition of international rock standards. Chemical Geology 166, 319-326.

Jeffcoate, A. B., Elliott, T., Kasemann, S. A., lonov, D., Cooper, K. \& Brooker, R. (2007). Li isotope fractionation in peridotites and mafic melts. Geochimica et Cosmochimica Acta 71, 202-218.

John, T., Gussone, N., Podladchikov, Y. Y., Bebout, G. E., Dohmen, R., Halama, R., Klemd, R., Magna, T., Seitz, H.-M. (2012). Volcanic arcs fed by rapid pulsed fluid flow through subducting slabs. Nature Geosciences 5, 489-492.

John, T., Klemd, R., Gao, J. \& Garbe-Schönberg C.D. (2008). Trace-element mobilization in slabs due to non steady-state fluid-rock interaction: Constraints from an eclogite-facies transport vein in blueschist (Tianshan, China), Lithos 103, 1-24.

Jonas, L., John, T., King, H. E., Geisler, T., Putnis, A. (2014). The role of grain boundaries and transient porosity in rocks as fluid pathways for reaction front propagation. Earth Planetary Science Letters 386, 64-74.

Kasemann, S. A., Jeffcoate, A. B. \& Elliott, T. (2005). Lithium isotope composition of basalt glass reference material. Analytical Chemistry 77, 5251-5257. 
Kodolányi, J., Pettke, T., Spandler, C., Kamber, B. S. \& Gméling, K. (2012). Geochemistry of ocean floor and fore-arc serpentinites: constraints on the ultramafic input to subduction zones. Journal of Petrology 53, 235-270.

Kohn, M. J., Valley, J. W., Elsenheimer, D. \& Spicuzza, M. J. (1993). Oxygen isotope zoning in garnet and staurolite. American Mineralogist 78, 988-1001.

Kretz, R. (1983). Symbols for rock-forming minerals. American Mineralogist 68, 277-279.

Kroner, U. \& Romer, R. L. (2013). Two plates-many subduction zones: the Variscan orogeny reconsidered. Gondwana Research 24, 298-329.

Lackey, J. S., Valley, J. W., Chen, J. H. \& Stockli, D. F. (2008). Dynamic magma systems, crustal recycling, and alteration in the Central Sierra Nevada Batholith: the oxygen isotope record. Journal of Petrology 49, 1397-1426.

Ledru, P., Autran, A. \& Santallier, D. (1994). Lithostratigraphy of Variscan terranes in the French Massif Central: a basis for paleogeographical reconstructions. In Keppie, J.D. (ed) Pre-mesozoic geology in France and related areas, Springer-Verlag, Berlin Heidelberg, 276-288.

Ledru, P., Lardeaux, J. M., Santallier, D., Autran, A., Quenardel, J. M., Floc'h, J. P., Lerouge, G., Maillet, N., Marchand, J. \& Ploquin, A. (1989). Où sont les nappes dans le Massif Central Français? Bulletin de la Société Géologique de France 3, 605-618.

Longerich, H. P., Jackson, S. E. \& Günther, D. (1996). Laser ablation inductively coupled plasma mass spectrometric transient signal data acquisition and analyte concentration calculation. Journal of Analytical Atomic Spectrometry 11, 899-904.

Marignac, C. \& Cuney, M. (1999). Ore deposits of the French Massif Central: insight into the metallogenesis of the Variscan collision belt. Mineralium Deposita 34, 472-504.

Marschall, H. R., Altherr, R., Ludwig, T., Kalt, A., Gméling, K. \& Kasztovszky, Zs. (2006). Partitioning and budget of $\mathrm{Li}, \mathrm{Be}$ and $\mathrm{B}$ in high-pressure metamorphic rocks. Geochimica et Cosmochimica Acta 70, 4750-4769. 
Marschall, H. R., Pogge von Strandmann, P. A. E., Seitz, H.-M., Elliott, T. \& Niu, Y. (2007). The lithium isotopic composition of orogenic eclogites and deep subducted slabs. Earth and Planetary Science Letters 262, 563-580.

Matte, P. (2001). The Variscan collage and orogeny (480-290 Ma) and the tectonic definition of the Armorica microplate: a review. Terra Nova 13, 122-128.

Melleton, J., Cocherie, A., Faure, M. \& Rossi, P. (2010). Precambrian protoliths and early Paleozoic magmatism in the French Massif Central: $\mathrm{U}-\mathrm{Pb}$ data and the North Gondwana connection in the west European Variscan belt. Gondwana Research 17, 13-25.

Mével, C. (2003). Serpentinization of abyssal peridotites at mid-ocean ridges. Comptes Rendus Geoscience 335, 825-852.

Millot, R., Guerrot, C. \& Vigier, N. (2004). Accurate and high- precision measurement of lithium isotopes in two reference materials by MC-ICP-MS. Geostandards Geoanalytical Research 28, 153-159.

Nance, R. D., Gutiérrez-Alonso, G., Keppie, J. D., Linnemann, U., Murphy, J. B., Quesada, C., Strachan, R. A. \& Woodcock, N. H. (2010). Evolution of the Rheic Ocean. Gondwana Research 17, 194-222.

Niu, Y. \& Batiza, R. (1997). Trace element evidence from seamounts for recycled oceanic crust in the eastern Pacific mantle. Earth and Planetary Science Letters 148, 471-483.

O’Hanley, D.S. (1996). Serpentinites, Oxford University Press, New York, 277 pp.

Paquette, J. L., Ballèvre, M., Peucat, J. J. \& Cornen, G. (2017). From opening to subduction of an oceanic domain constrained by LA-ICP-MS U-Pb zircon dating (Variscan belt, Southern Armorican Massif, France). Lithos 294-295, 418-437.

Penniston-Dorland S. C., Bebout, G. E., Pogge von Strandmann, P. A. E., Eliott, T. \& Sorensen, S. S. (2012). Lithium and its isotopes as tracers of subduction zone fluids and metasomatic processes: Evidence from the Catalina Schist, California, USA. Geochimica et Cosmochimica Acta 77, 530-545.

Penniston-Dorland, S. C., Liu, X.-M. \& Rudnick, R. L. (2017). Lithium isotope geochemistry. Reviews in Mineralogy and Geochemistry 82, 165-217. 
Penniston-Dorland, S. C., Sorensen, S. S., Ash, R. D. \& Khadke, S. V. (2010). Lithium isotopes as a tracer of fluids in a subduction zone mélange: Franciscan Complex, CA. Earth and Planetary Science Letters 292, 181-190.

Qiu, L., Rudnick, R. L., Ague, J. J. \& McDonough, W. F. (2011). A lithium isotopic study of sub-greenschist to greenschist facies metamorphism in an accretionary prism, New Zealand. Earth and Planetary Science Letters 301, 213-221.

Quinquis, H. (1980). Schistes bleus et déformation progressive: l'exemple de l'île de Groix. Thèse de 3ème cycle, Université de Rennes, 145 pp.

Quinquis, H. \& Choukroune, P. (1981). Les schistes bleus de l'île de Groix dans la chaîne Variscenne: implications cinématiques. Bulletin de la Société Géologique de France (7) XXIII, 409-418.

Richter, F. M., Davis, A. M., DePaolo, D. J. \& Watson, E. B. (2003). Isotope fractionation by chemical diffusion between molten basalt and rhyolite. Geochimica et Cosmochimica Acta 67, 3905-3923.

Romer, R. L. \& Meixner, A. (2014). Lithium and boron isotopic fractionation in sedimentary rocks during metamorphism - The role of rock composition and protolith mineralogy. Geochimica et Cosmochimica Acta 128, 158-177.

Ryan, J. G. \& Langmuir, C. H. (1987). The systematics of lithium abundances in young volcanic rocks. Geochimica et Cosmochimica Acta 51, 1727-1741.

Santallier, D., Briand, B., Ménot, R. P. \& Piboule, M. (1988). Les complexes leptynoamphiboliques (C.L.A.): revue critique et suggestions pour un meilleur emploi de ce terme. Bulletin de la Société Géologique de France 8 (IV), 3-12.

Scambelluri, M., Müntener, O., Ottolini, L., Pettke, T. T. \& Vanucci, R. (2004). The fate of B, $\mathrm{Cl}$ and $\mathrm{Li}$ in subducted oceanic mantle and in the antigorite breakdown fluids. Earth and Planetary Science Letters 222, 217-234.

Simons, K. K., Harlow, G. E., Brueckner, H. K., Goldstein, S. L., Sorensen, S. S., Hemming, N. G. \& Langmuir, C. H. (2010). Lithium isotopes in Guatemalan and Franciscan HP-LT 
rocks: insights into the role of sediment-derived fluids during subduction. Geochimica et Cosmochimica Acta 74, 3621-3641.

Siron, G., Baumgartner, L. P., Bouvier, A.-S., Putlitz, B. \& Vennemann, T. (2017). Biotite reference materials for secondary ion mass spectrometry ${ }^{18} \mathrm{O} /{ }^{16} \mathrm{O}$ measurements. Geostandards and Geoanalytical Research 41, 243-253.

Siron, G., Baumgartner, L. P., Bouvier, A.-S. \& Vennemann, T. (2018). Accurate Measurements of $\mathrm{H}_{2} \mathrm{O}, \mathrm{F}$ and $\mathrm{Cl}$ Content in Biotite using Secondary Ion Mass Spectrometry. Geostandards and Geoanalytical Research, doi: 10.1111/ggr.12235

Spandler, C. \& Hermann, J. (2006). High-pressure veins in eclogite from New Caledonia and their significance for fluid migration in subduction zones. Lithos 89, 135-153.

Stampfli, G. M., von Raumer, J. F., Wilhem, C. (2011) The distribution of Gondwana derived terranes in the early Paleozoic. In: Gutiérrez Marco JC, Rábano I, García-Bellido I (eds) The ordovician of the world. Instituto Geológico y Minero de España, Madrid, Cuadernos del Museo Geominero 14, 567-574.

Su, B.-X., Gu, X.-Y., Deloule, E., Zhang, H.-F., Li, Q.-L., Li, X.-H., Vigier, N., Tang, Y.-J., Tang, G.-Q., Liu, Y., Pang, K.-N., Brewer, A., Mao, Q. \& Ma, Y.-G. (2015). Potential orthopyroxene, clinopyroxene and olivine reference materials for in situ lithium isotope determination. Geostandards and Geoanalytical Research 39, 357-369.

Taetz, S., John, T., Bröcker, M., Spandler, C. (2016). Fluid-rock interaction and evolution of a high-pressure/low-temperature vein system in eclogite from New Caledonia: insights into intraslab fluid flow processes. Contributions to Mineralogy and Petrology 171, 90.

Taetz, S., John, T., Bröcker, M., Spandler, C. \& Stracke, A. (2018). Fast intraslab fluid-flow events linked to pulses of high pore fluid pressure at the subducted plate interface. Earth and Planetary Science Letters 482, 33-43.

Tang, Y. J., Zhang, H. F., Deloule, E., Su, B. X., Ying, J. F., Xiao, Y. \& Hu, Y. (2012). Slabderived lithium isotopic signatures in mantle xenoliths from northeastern North China Craton. Lithos 149, 79-90. 
Tang Y. J., Zhang H. F., Deloule, E., Su, B. X., Ying J. F., Santosh, M. \& Xiao Y. (2014). Abnormal lithium isotope composition from the ancient lithospheric mantle beneath the North China Craton. Scientific Reports 4, 4274.

Tang, Y. J., Zhang, H. F., Nakamura, E., Moriguti, T., Kobayashi, K. \& Ying, J. F. (2007). Lithium isotopic systematics of peridotite xenoliths from Hannuoba, North China Craton: implications for melt-rock interaction in the considerably thinned lithospheric mantle. Geochimica et Cosmochimica Acta 71, 4327-4341.

Tang, Y. J., Zhang, H. F. \& Ying, J. F., 2010. A brief review of isotopically light Li - a feature of the enriched mantle? International Geology Review 52, 964-976.

Teng, F.-Z., McDonough, W. F., Rudnick, R. L., Dalpé, C., Tomascak, P. B., Chappell, B. W. \& Gao, S. (2004). Lithium isotopic composition and concentration of the upper continental crust. Geochimica et Cosmochimica Acta 68, 4167-4178.

Teng, F.-Z., McDonough, W. F., Rudnick, R. L. \& Walker, R. J. (2006). Lithium isotopic systematics of granites and pegmatites from the Black Hills, South Dakota. American Mineralogist 91, 1488-1498.

Tomascak, P. B., 2004. Developments in the understanding and application of lithium isotopes in the Earth and Planetary Sciences. In: Johnson, C.M., Beard, B.L., Albarède, F. (Eds.), Geochemistry of non-traditional stable isotopes: Mineralogical Society of America, Reviews in Mineralogy and Geochemistry 55, 153-195.

Tomascak, P. B., Langmuir, C. H., Le Roux, P. J. \& Shirey, S. B. (2008). Lithium isotopes in global mid-ocean ridge basalts. Geochimica et Cosmochimica Acta 72, 1626-1637.

Tomascak, P. B., Ryan, J. G. \& Defant, M. J. (2000). Lithium isotope evidence for light element decoupling in the Panama subarc mantle. Geology 28, 507-510.

Tomascak, P. B., Widom, E., Benton, L. D., Goldstein, S. L. \& Ryan, J. G. (2002). The control of lithium budgets in island arcs. Earth and Planetary Science Letters 196, 227238. 
Vielzeuf, D., Veschambre, M., Brunet, F. (2005). Oxygen isotope heterogeneities and diffusion profile in composite metamorphic-magmatic garnets from the Pyrenees. American Mineralogist 90, 463-472.

Vigier, N., Decarreau, A., Millot, R., Carignan, J., Petit, S. \& France-Lanord, C. (2008). Quantifying $\mathrm{Li}$ isotope fractionation during smectite formation and implications for the $\mathrm{Li}$ cycle. Geochimica et Cosmochimica Acta 72, 780-792.

Vils, F., Pelletier, L., Kalt, A., Müntener, O. \& Ludwig, T. (2008). The Lithium, Boron and Beryllium content of serpentinized peridotites from ODP Leg 209 (Sites 1272A and 1274A): Implications for lithium and boron budgets of oceanic lithosphere. Geochimica et Cosmochimica Acta 72, 5475-5504.

Viti, C. \& Mellini, M. (1998). Mesh textures and bastites in the Elba retrograde serpentinites. European Journal of Mineralogy 10, 1341-1359.

von Raumer, J., Bussy, F., Schaltegger, U., Schulz, B., \& Stampfli, G. M. (2013). PreMesozoic Alpine basements - their place in the European Paleozoic framework. Geological Society of America Bulletin 125, 89-108.

Von Raumer, J., Stampfli, G. M., Arenas, R. \& Martínez, S. S. (2015). Ediacaran to Cambrian oceanic rocks of the Gondwana margin and their tectonic interpretation. International Journal of Earth Sciences 104, 1107-1121.

Wan, H., Sun, H., Liu, H. \& Xiao, Y. (2017). Lithium isotopic geochemistry in subduction zones: retrospects and prospects. Acta Geologica Sinica 91, 688-710.

Woodland, A. B., Seitz, H.-M., Altherr, R., Olker, B., Marschall, H. \& Ludwig, T. (2002). Lithium abundances in eclogite minerals: a clue to a crustal or mantle origin? Contributions to Mineralogy and Petrology 144, 128-129.

Wunder, B., Deschamps, F., Watenphul, A., Guillot, S., Meixner, A., Romer, R. \& Wirth, R. (2010). The effect of chrysotile nanotubes on the serpentine-fluid Li-isotopic fractionation. Contributions to Mineralogy and Petrology 159, 781-790. 
Wunder, B., Meixner, A., Romer, R. L. \& Heinrich, W. (2006) Temperature-dependent isotopic fractionation of lithium between clinopyroxene and high-pressure hydrous fluids. Contributions to Mineralogy and Petrology 151, 112-120.

Wunder, B., Meixner, A., Romer, R. L. \& Jahn, S. (2011). Li-isotope fractionation between silicates and fluids: pressure dependence and influence of the bonding environment. European Journal of Mineralogy 23, 333-342.

Wunder, B., Meixner, A., Romer, R. L., Feenstra, A., Schettler, G. \& Heinrich, W. (2007). Lithium isotope fractionation between Li-bearing staurolite, Li-mica and aqueous fluids: an experimental study. Chemical Geology 238, 277-290.

Xiao, Y., Hoefs, J., Hou, Z., Simon, K. \& Zhang, Z. (2011). Fluid/rock interaction and mass transfer in continental subduction zones: constraints from trace elements and isotopes $(\mathrm{Li}$, $\mathrm{B}, \mathrm{O}, \mathrm{Sr}, \mathrm{Nd}, \mathrm{Pb}$ ) in UHP rocks from the Chinese Continental Scientific Drilling Program, Sulu, East China. Contributions to Mineralogy and Petrology 162, 797-819.

You, C. F., Castillo, P. R., Gieskes, J. M., Chan, L. H. \& Spivack, A. J. (1996). Trace element behavior in hydrothermal experiments: Implications for fluid processes at shallow depths in subduction zones. Earth and Planetary Science Letters 140, 41-52.

Zack, T., Tomascak, P. B., Rudnick, R. L., Dalpe, C. \& McDonough, W. F. (2003). Extremely light $\mathrm{Li}$ in orogenic eclogites: the role of isotope fractionation during dehydration in subducted oceanic crust. Earth and Planetary Science Letters 208, 279-290. 


\section{LIST OF FIGURES}

Figure 1. (a) General sketch of the Variscan Belt in Western Europe (after Berger et al., 2005; Ballèvre et al., 2014). The Limousin ophiolite and the lle de Groix HP terrane are parts of the Middle Allochthon domain and belong to the series of ophiolites recognised along the Galicia-Brittany-French Massif Central suture zone. The latter was interpreted as the remnant of a narrow ocean between Gondwana and Armorica (Matte, 2001) or a lateCambrian active margin setting along the Gondwana (von Raumer et al., 2015). (b) Geological map of the studied area in the Limousin ophiolite (modified after Berger et al., 2005, 2010a, 2010b). c) Geological map of the lle de Groix (after Audren et al., 1993; Bosse et al., 2002; El Korh et al., 2009, 2013). *The beach "Plage des Grands Sables" has moved with the oceanic currents. FMC: French Massif Central; VM: Vosges Massif; BF: Black Forest; LC: Lizard Complex; AM: Armorican Massif; Py: Pyrénées; ECM: External Crystalline Massifs of the Alps; RM: Rhenish Massif; RHZ: Rheno-Hercynian zone; STZ: SaxoThuringian zone; MZ: Moldanubian zone.

Figure 2. Photomicrographs of studied samples from the Limousin ophiolite (a-d) and Ile de Groix HP-LT terrane (e-f) in plane-polarised light. (a) Typical assemblage of serpentine, spinel, chlorite and tremolite in the serpentinite LAU2 from Saint-Laurent; (b) Serpentinite CLUZ6 from Le Cluzeau composed of serpentine, spinel, chlorite and tremolite, with relicts of olivine and pyroxene; (c) Fine grained and slightly foliated amphibolite CLUZ1 consisting of hornblende and plagioclase; (d) Plagioclase-amphibole symplectite around a hornblende aggregate in isotropic amphibolite CLUZ 4; (e) Garnet-omphacite-glaucophane-clinozoisite assemblage in eclogite GR 29. Partial retrogression is evidenced by titanite overgrowths around rutile, barroisite overgrowths on the rims of glaucophane and by the presence of barroisite-albite symplectites on the rims of omphacite; (f) Retrogression is more pronounced in eclogite GR 24a: rutile is totally replaced by titanite, barroisite-albite symplectites along omphacite are well developed and garnet is partially altered in chlorite + iron hydroxides. 
Quartz veins parallel to the main schistosity are also present. Mineral abbreviations are from Kretz (1983). "Sympl" = Albite and barroisite symplectites.

Figure 3. Variation in Li abundances in whole rocks and minerals from the Limousin ophiolite. The Li composition of fresh MORB is from Ryan \& Langmuir (1987) and Niu \& Batiza (1997). WR: whole rock

Figure 4. Variation of the mean $\delta^{7} \mathrm{Li}$ values relative to $\mathrm{Li}$ abundances in the minerals from the rocks of the Limousin ophiolite. Amphibole in serpentinites and amphibolites is mainly tremolite and hornblende, while amphibole in the UHP eclogite L04-143 is pargasite. Error bars are $2 \sigma \mathrm{SD}$. The Li elemental composition of fresh MORB is from Ryan \& Langmuir (1987) and Niu \& Batiza (1997). The Li isotopic composition is from Chan et al. (2002), Bouman et al. (2004) and Tomascak et al. (2008).

Figure 5. Variation in Li abundances in whole rocks and minerals from the lle de Groix HP terrane. The Li composition of fresh MORB is from Ryan \& Langmuir (1987) and Niu \& Batiza (1997). The Li composition of altered MORB is from Chan et al. (2002), Bouman et al., (2004) and Coogan et al. (2017). BS: blueschists; Ecl: eclogites; GS: greenschists; MS: micaschists; Micas: phengite + paragonite

Figure 6. (a) Li isotopic composition of the metabasites and micaschists of the lle de Groix. The $\delta^{7} \mathrm{Li}$ values decrease from the blueschist facies to the eclogite facies. During retrogression, the $\delta^{7} \mathrm{Li}$ values increase with the intensity of rehydration. (b) $\delta^{7} \mathrm{Li}$ values vs. $\mathrm{Li}$ abundances. No correlation is observed with the variation of the metamorphic facies. Error bars for $\delta^{7} \mathrm{Li}$ values are $2 \sigma \mathrm{SE}$, as the whole rock $\delta^{7} \mathrm{Li}$ is calculated by averaging replicate analyses of the same sample solution. 
Figure 7. Variations in $\mathrm{Li}$ content and isotopic composition of glaucophane and omphacite from the metabasites of the lle de Groix. (a) Mean $\delta^{7} \mathrm{Li}$ vs. Lithium contents. Mean Li abundances were calculated using the LA-ICPMS data. Mean $\delta^{7} \mathrm{Li}$ values correspond to unweighted average of all in-situ $\delta^{7} \mathrm{Li}$ values measured by SIMS in each sample. Error bars are $2 \sigma$ SD. The dark grey field represents the Li composition of fresh MORB (Ryan \& Langmuir, 1987; Niu \& Batiza, 1997; Chan et al., 2002; Bouman et al., 2004; Tomascak et al., 2008) (b-f) Core-to-rim variations of the $\delta^{7} \mathrm{Li}$ values and $\mathrm{Li}$ contents in $(\mathrm{b}-\mathrm{c})$ blueschists and, (d-f) eclogites. The dotted lines and grey field give the corresponding whole rock and $2 \sigma$ SE values. Individual $\mathrm{Li}$ abundances were calculated based on the mean $\mathrm{Li}$ contents obtained by LA-ICPMS and ${ }^{6+7} \mathrm{Li}$ intensities, as follows:

$$
C(L i)_{i}^{S I M S}=\left[I(L i)_{i}^{S I M S} x C(L i)_{\text {mean }}^{L A-I C P M S}\right] / C(L i)_{\text {mean }}^{S I M S}
$$

Figure 8. Calculated Li isotope composition of fluids in equilibrium with rocks and minerals in the rocks from: (a) the Limousin ophiolite and, (b) the lle de Groix. $\delta^{7} \mathrm{Li}_{\text {fluid }}$ calculations were made using the clinopyroxene-fluid fractionation factors for amphiboles, omphacite and whole rocks, and the mica-fluid fractionation factor for serpentine (Wunder et al., 2006, 2011): $\delta^{7} \mathrm{Li}_{\text {fluid }}=\delta^{7} \mathrm{Li}_{\text {sample }}-\Delta^{7} \mathrm{Li}_{\text {mineral-fluid }}$. The $2 \sigma$ uncertainties, represented by the error bars, are identical to those of the mean $\delta^{7} \mathrm{Li}$ of minerals and whole rocks employed for calculation. (a) The $\delta^{7} \mathrm{Li}$ values of the fluids in equilibrium with serpentine were calculated for $350^{\circ} \mathrm{C}$ and $500^{\circ} \mathrm{C}$, as the temperature of hydrothermal alteration is not precisely constrained. (b) It is assumed that glaucophane rims have formed at a temperature $50^{\circ} \mathrm{C}$ higher than glaucophane core. 


\section{LIST OF TABLES}

Table 1. Provenance and mineral assemblage of the studied rocks

Table 2. Lithium abundances in the rocks from the Limousin ophiolite (in ppm)

Table 3. In-situ SIMS measurements of mineral Li contents (in ppm) and isotopic composition (in \%o) for the Limousin ultrabasic and basic rocks. Calculated Li fractionation factors (in \%o) are given for mineral-mineral pairs.

Table 4. Lithium contents (in ppm) and MC-ICPMS isotopic data (in \%o) of the rocks from the lle de Groix

Table 5. Lithium abundances in the metamorphic minerals from the rocks of the lle de Groix measured by LA-ICPMS (in ppm)

Table 6. Lithium isotopic composition measured by SIMS in the metabasites of the lle de Groix (in \%o). Calculated Li fractionation factors (in \%) are given for mineral-mineral and whole rock-mineral pairs. WR: whole rock

Table 7. Calculated Li isotopic composition of fluids in equilibrium with the minerals of the Limousin ultrabasic and basic rocks (in \%o)

Table 8. Calculated $\mathrm{Li}$ isotopic composition of fluids in equilibrium with glaucophane, omphacite and whole metabasic rocks from the lle de Groix (in \%o) 


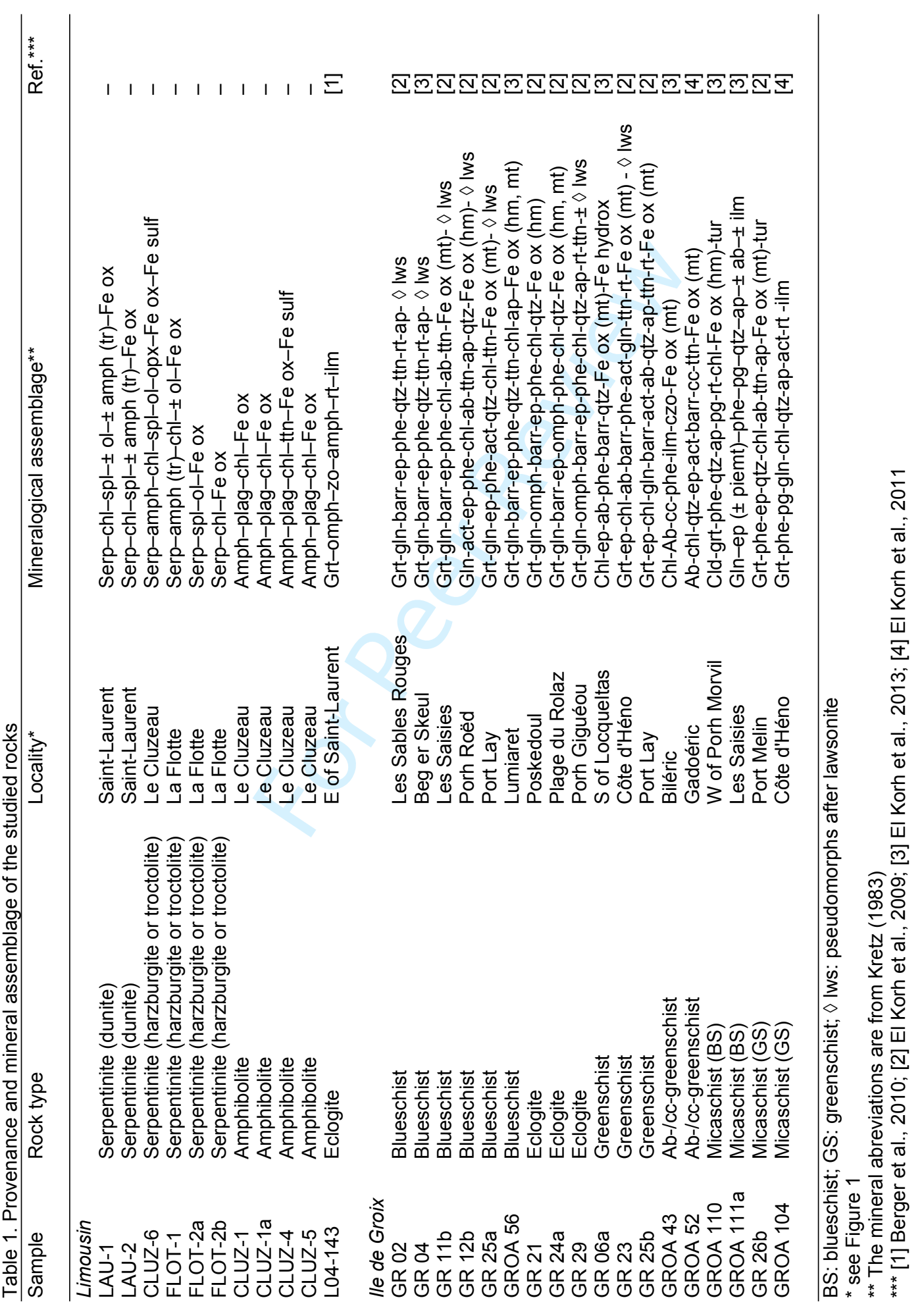

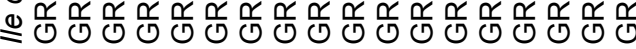


Table 2. Lithium abundances in the rocks from the Limousin ophiolite (in ppm)

Samples

Serpentinites

LAU-1 2.4

LAU-2 4.6

CLUZ-6 $\quad 1.9$

FLOT-2a $\quad 3.0$

FLOT-2b

0.9

Amphibolites

CLUZ-1 5.5

CLUZ-1a $\quad 8.2$

CLUZ-4 $\quad 3.1$

CLUZ-5 $\quad 6.6$

UHP zoisite-eclogite

L04-143

2.3 
Table 3. In-situ SIMS measurements of mineral Li contents (in ppm) and isotopic composition (in \%o) for the Limousin ultrabasic and basic rocks. Calculated $\mathrm{Li}$ fractionation factors $\left(\Delta^{7} \mathrm{Li}\right.$, in $\%$ ) are given for mineral-mineral pairs.

\begin{tabular}{|c|c|c|c|c|c|c|c|c|c|c|c|}
\hline & $\begin{array}{l}\mathrm{Li}(\mathrm{ppm}) \\
\text { min-max }\end{array}$ & mean & $2 \sigma S D$ & & $\begin{array}{l}\delta 7 \mathrm{Li} \\
\min \end{array}$ & $\max$ & mean & $2 \sigma S D$ & $\mathrm{n}$ & $\begin{array}{l}\Delta^{7} \mathrm{Li} \\
\text { mean }\end{array}$ & $2 \sigma^{*}$ \\
\hline \multicolumn{12}{|l|}{ Serpentinite LAU2 } \\
\hline chl & $0.67-1.0$ & 0.83 & 0.32 & 6 & & & & & & & \\
\hline spl & $0.27-2.6$ & 1.5 & 3.4 & 2 & & & & & & & \\
\hline Fe-rich serp & $1.3-6.7$ & 3.2 & 3.4 & 13 & -10.4 & -6.7 & -8.7 & 3.1 & 7 & & \\
\hline Mg-rich serp & $0.7-2.5$ & 1.4 & 0.9 & 19 & -12.4 & -3.5 & -8.9 & 5.2 & 10 & & \\
\hline Fe-rich serp-Mg-rich serp & & & & & & & & & & +0.2 & 6.0 \\
\hline \multicolumn{12}{|l|}{ Serpentinite CLUZ6 } \\
\hline & $0.45-0.75$ & 0.54 & 0.29 & 2 & & & & & & & \\
\hline amph & $1.4-3.5$ & 2.5 & 3.0 & 4 & +4.5 & +9.5 & +6.6 & 4.6 & 4 & & \\
\hline Fe-rich serp & $1.2-8.2$ & 4.5 & 4.5 & 10 & -4.2 & +1.3 & -2.2 & 3.0 & 12 & & \\
\hline Mg-rich serp & $0.76-3.6$ & 2.0 & 1.2 & 22 & -0.7 & +7.0 & +4.2 & 3.5 & 21 & & \\
\hline Fe-rich serp-Mg-rich serp & & & & & & & & & & -6.3 & 4.6 \\
\hline Fe-rich serp-amph & & & & & & & & & & -8.8 & 5.5 \\
\hline Mg-rich serp-amph & & & & & & & & & & -2.5 & 5.8 \\
\hline
\end{tabular}

Serpentinite FLOT1

amph

chl

Fe-rich serp

Mg-rich serp

Serpentinite FLOT2a

ol

Mg-rich serp

$\mathrm{spl}$

Mg-rich serp-ol

$\begin{array}{llll}1.1-1.9 & 1.3 & 0.8 & 4 \\ 0.24-0.60 & 0.42 & 0.51 & 2 \\ 4.2 & 4.2 & - & 1 \\ 0.77-2.2 & 1.2 & 1.0 & 9\end{array}$

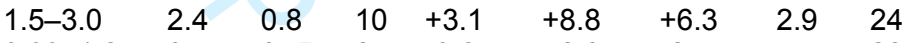

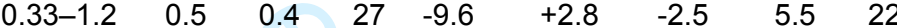

$\begin{array}{llll}2.1-2.3 & 2.2 & 0.3 & 2\end{array}$

Amphibolite CLUZ1

amph

$\begin{array}{lllllllll}1.7-8.4 & 5.3 & 3.5 & 14 & -0.2 & +6.9 & +3.5 & 4.4 & 17\end{array}$

$\begin{array}{lllllllll}1.3-3.5 & 2.4 & 3.1 & 2 & +9.4 & +10.1 & +9.8 & 0.9 & 2\end{array}$

plag

$\begin{array}{llll}0.11-1.0 & 0.44 & 1.02 & 3\end{array}$

Amphibolite CLUZ4

amph

$\begin{array}{lllllllll}1.4-11 & 3.5 & 6.2 & 8 & +2.9 & +18.2 & +12.5 & 9.6 & 13\end{array}$

plag

$0.09-0.94 \quad 0.39 \quad 0.60 \quad 8$

UHP eclogite L04-143

amph

$\begin{array}{lllllllll}1.2-25 & 9.5 & 12.6 & 12 & +12.2 & +24.2 & +18.7 & 7.2 & 13\end{array}$

$\begin{array}{lllllllll}1.5-10 & 4.2 & 6.6 & 19 & +16.7 & +26.3 & +21.9 & 5.0 & 21\end{array}$

$\begin{array}{llll}0.15-0.90 & 0.36 & 0.39 & 8\end{array}$

$\begin{array}{llll}0.03-0.38 & 0.11 & 0.19 & 12\end{array}$

$\begin{array}{llll}0.19-5.7 & 3.0 & 7.8 & 2\end{array}$

amph-omph

* Propagated $2 \sigma$ uncertainties 
Table 4. Lithium contents (in ppm) and MC-ICPMS isotopic data (in \%) of the rocks from the lle de Groix

\begin{tabular}{lllll}
\hline & Li & $\delta^{7} \mathrm{Li}$ & $2 \sigma \mathrm{SE}^{*}$ & $\mathrm{n}^{\text {** }}$ \\
\hline Blueschists & & & & \\
GR 02 & 45 & 0.74 & - & 1 \\
GR 04 & 16.2 & n.a. & - & \\
GR 11b & 70 & -0.60 & 0.23 & 3 \\
GR 12b & 124 & n.a. & - & \\
GR 25a & 39 & -0.60 & 0.10 & 3 \\
GROA 56 & 55 & n.a. & - & \\
Eclogites & & & & \\
GR 21 & 18 & -4.12 & 0.38 & 3 \\
GR 24a & 28 & -2.46 & 0.12 & 3 \\
GR 29 & 102 & -4.75 & 0.26 & 3 \\
& & & & \\
Greenschists & & & & \\
GR 06a & 74 & 3.16 & 0.59 & 3 \\
GR 23 & 58 & -4.51 & 0.51 & 3 \\
GR 25b & 37 & -0.14 & 0.52 & 3 \\
GROA 43 & 62 & n.a. & - & \\
GROA 52 & 45 & 1.45 & 0.39 & 2 \\
& & & & \\
Micaschists & & & & \\
GROA 110 & 15 & 0.18 & 0.43 & 3 \\
GROA 111a & 48 & -1.68 & 0.73 & 3 \\
GR 26b & 50 & n.a. & - & \\
GROA 104 & 52 & n.a. & - & \\
& & & &
\end{tabular}

${ }^{\star} 2 \sigma$ standard error (i.e. $2 \sigma$ standard deviations of the mean) calculated on the basis of replicate analyses of the same sample solution

${ }^{* *} \mathrm{n}=$ number of replicates for $\mathrm{Li}$ isotope measurements; 
1

2 3

Table 5. Lithium abundances in the metamorphic minerals from the rocks of the lle de Groix measured by LA-ICPMS (in ppm)

\begin{tabular}{|c|c|c|c|c|c|}
\hline Mineral & Sample & Li abundar & & mean & $2 \sigma S D$ \\
\hline & & this study & {$[1,2]^{*}$} & & \\
\hline Prograd & ninerals in & basites & & & \\
\hline ap & GR29 & - & 2.6 & 2.6 & - \\
\hline ap & GR25b & - & $0.49-0.58$ & 0.53 & 0.12 \\
\hline ep & GR02 & - & $0.78-3.4$ & 2.3 & 19 \\
\hline ep & GR11b & - & $4.8-9.4$ & 6.6 & 4.9 \\
\hline ep & GR12b & $2.0-41$ & $0.67-26$ & 9.9 & 22 \\
\hline ep & GR25a & - & $1.6-9.7$ & 5.8 & 7.4 \\
\hline ep & GR21 & - & $1.2-5.1$ & 3.1 & 2.7 \\
\hline ep & GR24a & - & $2.6-5.7$ & 4.1 & 2.7 \\
\hline ep & GR29 & $1.3-10$ & 5.6 & 3.9 & 17 \\
\hline ep & GR23 & $17-31$ & $1.3-22$ & 7.9 & 14 \\
\hline ep & GR25b & - & $2.2-7.2$ & 3.7 & 3.5 \\
\hline grt & GR02 & - & $0.47-1.1$ & 0.72 & 0.52 \\
\hline grt & GR21 & - & $0.49-0.63$ & 0.57 & 0.15 \\
\hline grt & GR29 & 1.5 & - & 1.5 & - \\
\hline grt & GR23 & - & $0.86-1.3$ & 1.1 & 0.5 \\
\hline grt & GR25b & - & $0.57-1.5$ & 0.95 & 1.03 \\
\hline gln & GR02 & 84-103 & - & 94 & 28 \\
\hline gln & GR11b & - & 209-319 & 270 & 106 \\
\hline gln & GR12b & $295-401$ & - & 360 & 253 \\
\hline gln & GR25a & $67-90$ & - & 77 & 35 \\
\hline gln & GR21 & - & $81-215$ & 115 & 91 \\
\hline gln & GR24a & $88-113$ & $48-74$ & 72 & 46 \\
\hline gln & GR29 & 110-295 & - & 179 & 142 \\
\hline gln & GR25b & $77-252$ & $121-129$ & 144 & 119 \\
\hline omph & GR21 & - & $41-61$ & 47 & 14 \\
\hline omph & GR24a & $32-33$ & $27-31$ & 31 & 5 \\
\hline omph & GR29 & $111-145$ & $90-118$ & 107 & 28 \\
\hline phe & GR02 & - & 16 & 16 & - \\
\hline phe & GR11b & - & $26-39$ & 32 & 8.0 \\
\hline phe & GR12b & - & $9-33$ & 23 & 25 \\
\hline phe & GR21 & - & $21-33$ & 26 & 9.2 \\
\hline phe & GR24a & - & $4.4-9.1$ & 6.8 & 3.9 \\
\hline phe & GR23 & $25-27$ & $41-46$ & 37 & 20 \\
\hline phe & GR25b & - & $5.8-7.1$ & 6.5 & 1.8 \\
\hline ttn & GR02 & - & $1.3-8.2$ & 4.6 & 6.1 \\
\hline $\operatorname{ttn}$ & GR11b & - & 7.3 & 7.4 & - \\
\hline $\operatorname{ttn}$ & GR12b & - & 17 & 17 & - \\
\hline $\operatorname{ttn}$ & GR25a & $1.6-10$ & - & 5.9 & 12 \\
\hline $\operatorname{ttn}$ & GR24a & - & $4.8-7.0$ & 5.9 & 1.8 \\
\hline $\mathrm{ttn}$ & GR23 & - & 14-15 & 15 & 1 \\
\hline ttn & GR25b & - & 2.9 & 2.9 & - \\
\hline
\end{tabular}

Retrograde minerals in metabasites

\begin{tabular}{llllll} 
ab & GR29 & $174-212$ & - & 193 & 53 \\
ab & GR25b & - & 41 & 41 & - \\
act & GR12b & $5.7-8.1$ & - & 6.7 & 2.3 \\
act & GR25b & - & $2.0-19$ & 7.7 & 11.8 \\
barr & GR11b & - & $5.1-9.4$ & 7.3 & 6.1 \\
barr & GR21 & - & 9 & 9 & - \\
barr & GR24a & - & $3.1-9.6$ & 6.4 & 9.2 \\
chl & GR11b & - & $69-182$ & 107 & 87 \\
chl & GR12b & $106-126$ & $126-127$ & 119 & 17 \\
chl & GR25a & $27-33$ & - & 30 & 8 \\
chl & GR25b & $13-50$ & $46-61$ & 43 & 33 \\
& & & & & \\
Minerals in & micaschists & & & & \\
cld & GROA110 & - & $0.31-1.2$ & 0.75 & 1.24 \\
phe & GROA110 & - & $20-26$ & 22 & 4.0 \\
phe & GR26b & $33-52$ & $38-61$ & 45 & 15 \\
pg & GROA110 & - & 28 & 28 & - \\
grt & GR26b & - & $3.1-5.0$ & 3.9 & 2.0 \\
chl & GR26b & 180 & $150-185$ & 170 & 28 \\
ep & GR26b & - & 4.2 & 4.2 & - \\
ap & GR26b & - & 2.8 & 2.8 & - \\
ttn & GR26b & - & 3.6 & 3.6 & - \\
tur & GR26b & 47 & $19-27$ & 29 & 25 \\
\hline$*$
\end{tabular}

* Data from: [1] El Korh et al. (2009); [2] El Korh (2010) 
Table 6. Lithium isotopic composition measured by SIMS in the metabasites of the lle de Groix (in \%o). Calculated Li fractionation factors $\left(\Delta^{7} \mathrm{Li}\right.$, in \%o) are given for mineral-mineral and whole rock-mineral pairs. WR: whole rock

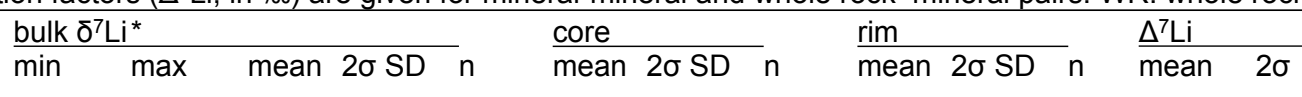

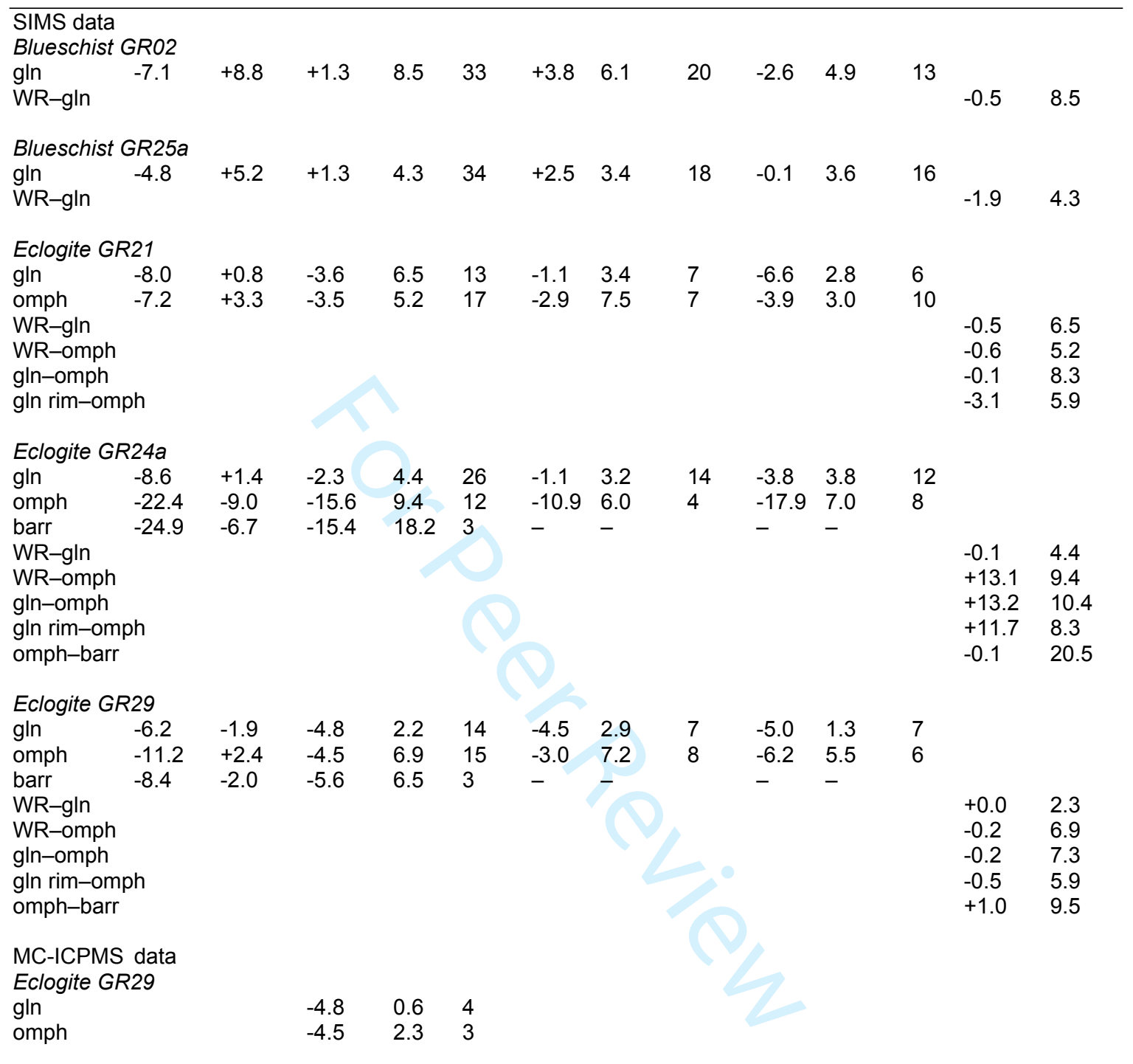

${ }^{*}$ Mean $\delta^{7} \mathrm{Li}$ values for bulk mineral correspond to unweighted average of all measured data, without considering core/rim proportion. 


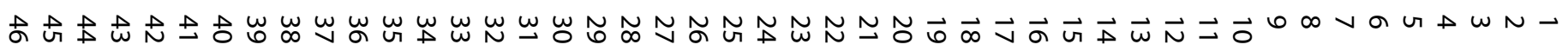

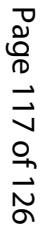

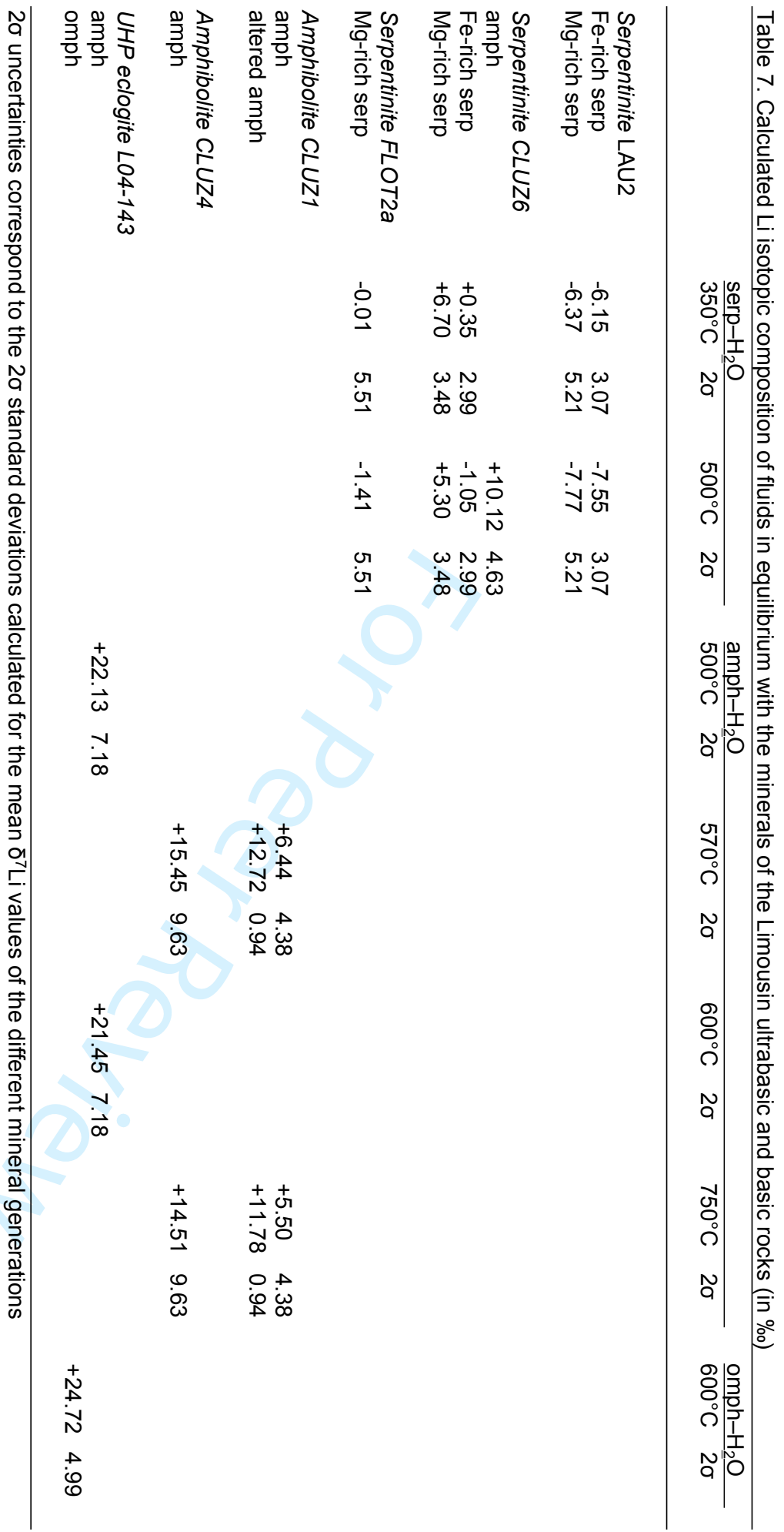




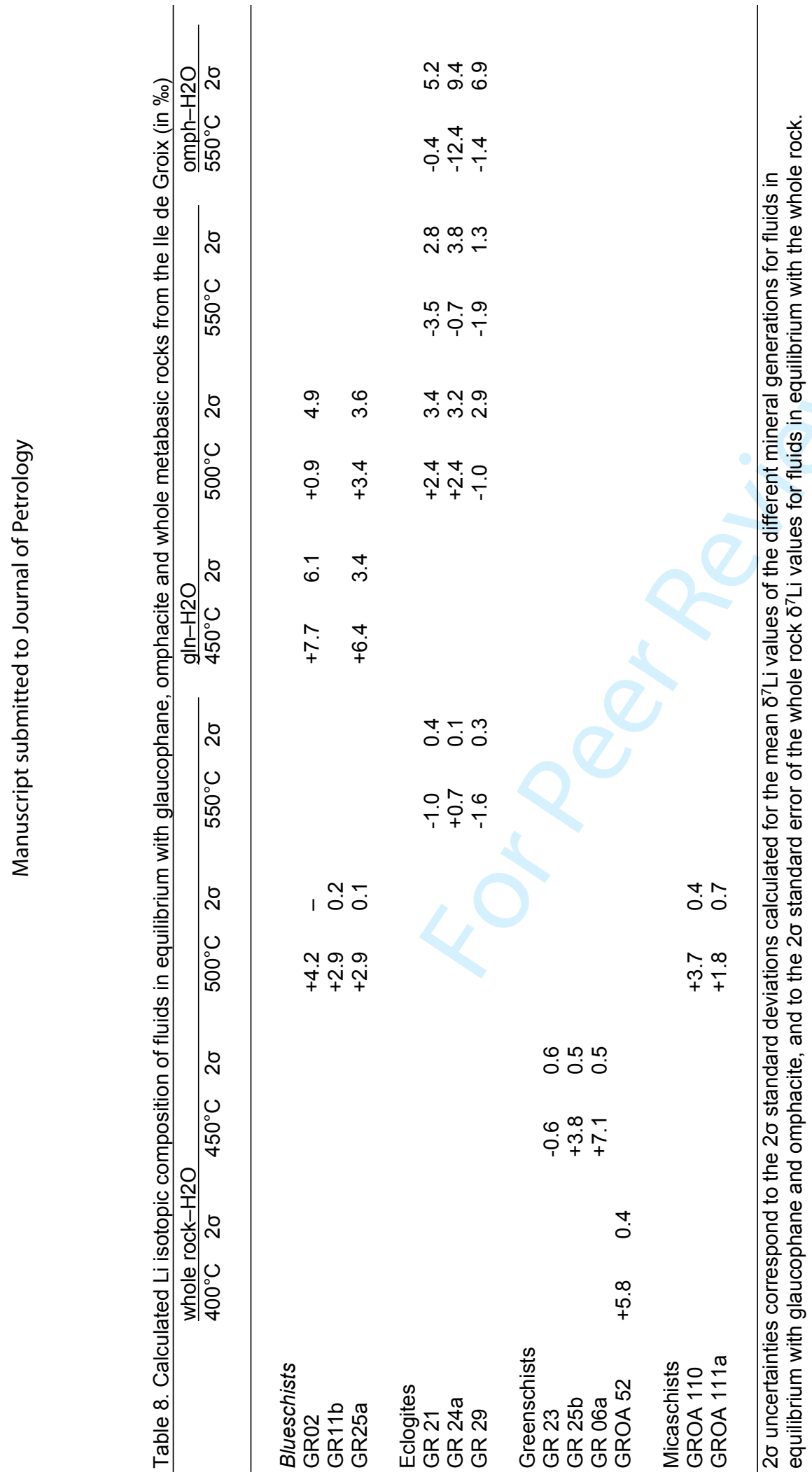




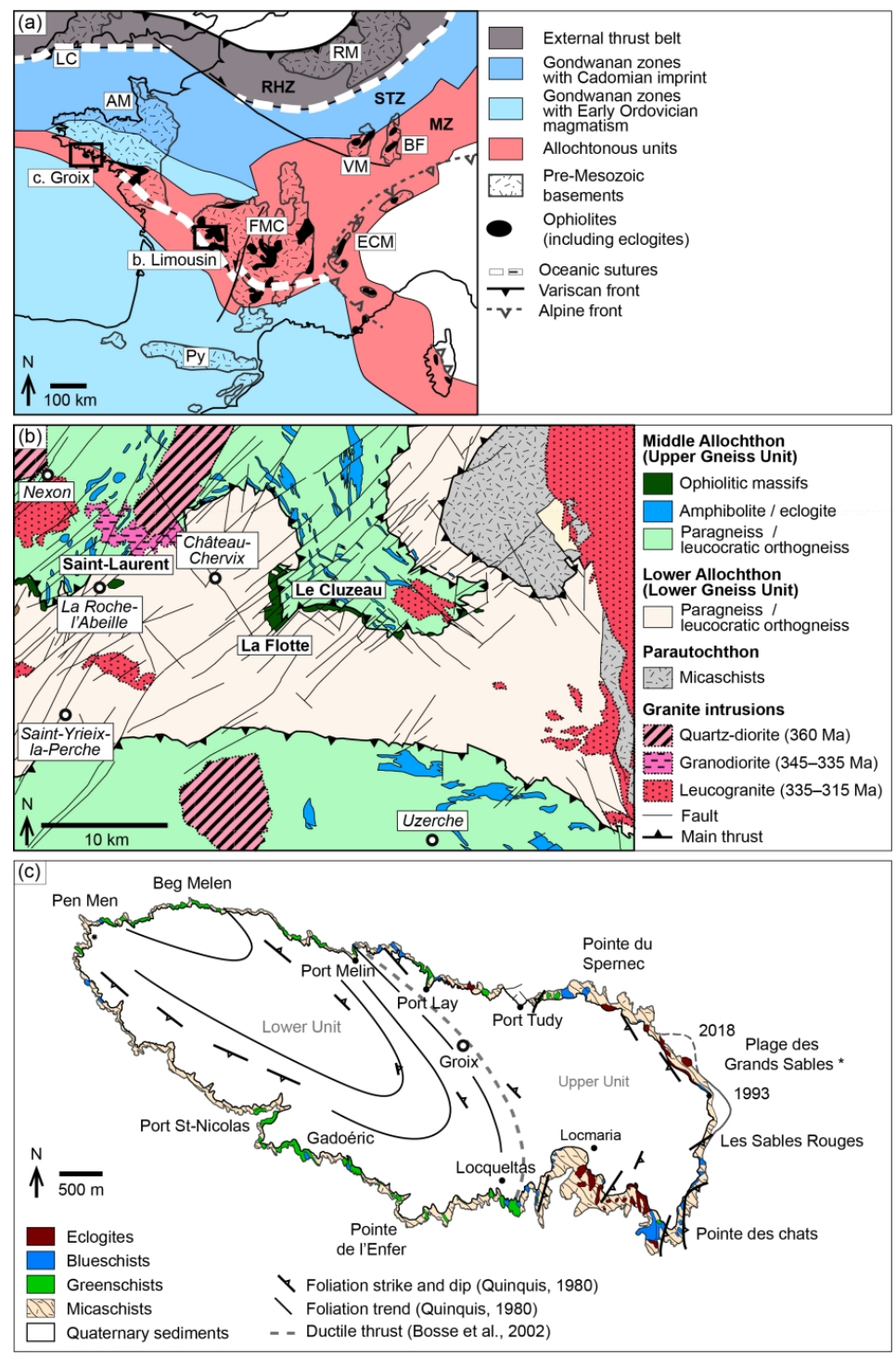

Figure 1. (a) General sketch of the Variscan Belt in Western Europe (after Berger et al., 2005; Ballèvre et al., 2014). The Limousin ophiolite and the Ile de Groix HP terrane are parts of the Middle Allochthon domain and belong to the series of ophiolites recognised along the Galicia-Brittany-French Massif Central suture zone. The latter was interpreted as the remnant of a narrow ocean between Gondwana and Armorica (Matte, 2001) or a late-Cambrian active margin setting along the Gondwana (von Raumer et al., 2015). (b) Geological map of the studied area in the Limousin ophiolite (modified after Berger et al., 2005, 2010a, 2010b). c) Geological map of the Ile de Groix (after Audren et al., 1993; Bosse et al., 2002; El Korh et al., 2009, 2013). *The beach "Plage des Grands Sables" has moved with the oceanic currents. FMC: French Massif Central; VM: Vosges Massif; BF: Black Forest; LC: Lizard Complex; AM: Armorican Massif; Py: Pyrénées; ECM: External Crystalline Massifs of the Alps; RM: Rhenish Massif; RHZ: Rheno-Hercynian zone; STZ: Saxo-Thuringian zone; MZ: Moldanubian zone. 

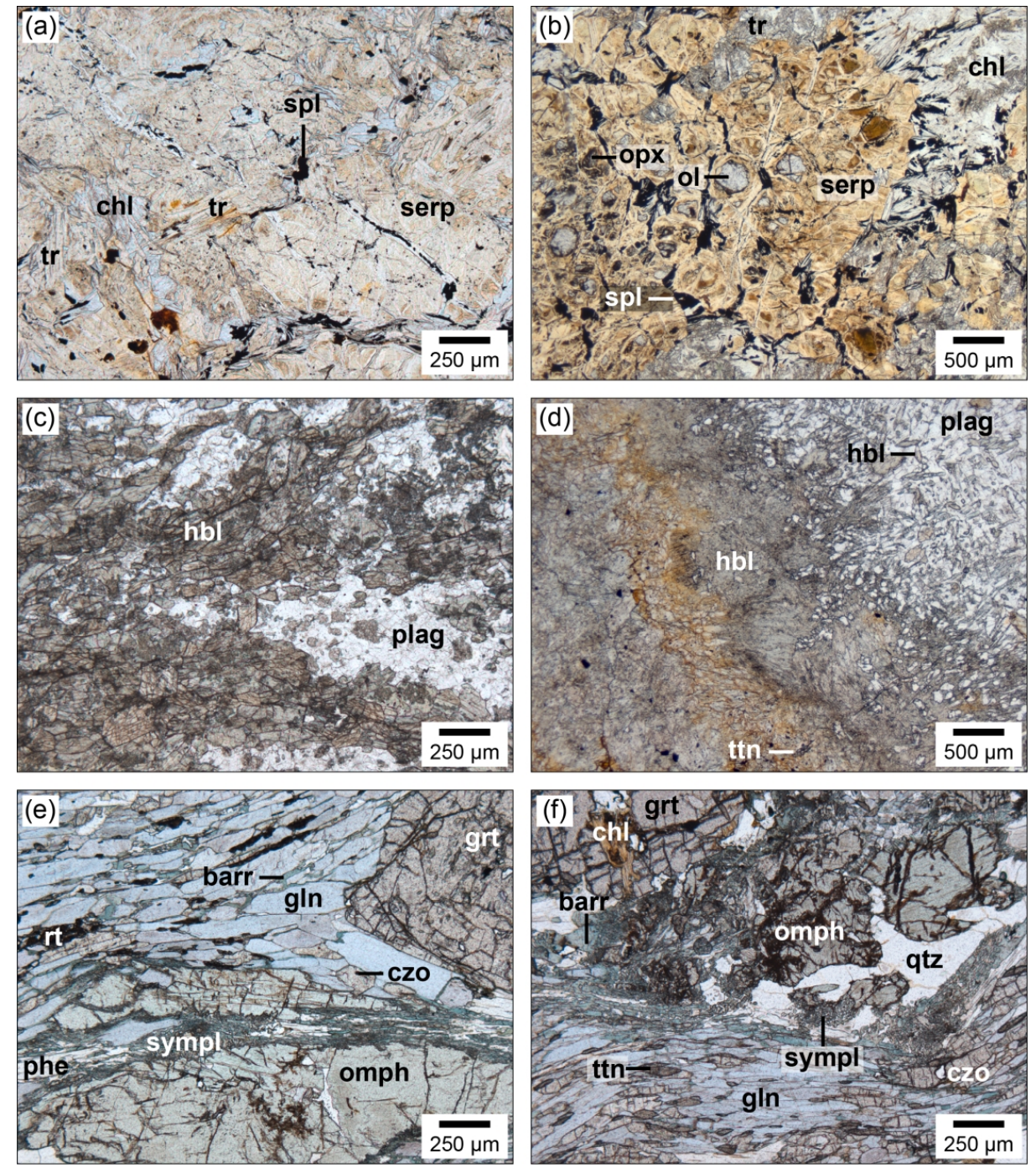

Figure 2. Photomicrographs of studied samples from the Limousin ophiolite (a-d) and Ile de Groix HP-LT terrane (e-f) in plane-polarised light. (a) Typical assemblage of serpentine, spinel, chlorite and tremolite in the serpentinite LAU2 from Saint-Laurent; (b) Serpentinite CLUZ6 from Le Cluzeau composed of serpentine, spinel, chlorite and tremolite, with relicts of olivine and pyroxene; (c) Fine grained and slightly foliated amphibolite CLUZ1 consisting of hornblende and plagioclase; (d) Plagioclase-amphibole symplectite around a hornblende aggregate in isotropic amphibolite CLUZ 4; (e) Garnet-omphacite-glaucophane-clinozoisite assemblage in eclogite GR 29. Partial retrogression is evidenced by titanite overgrowths around rutile, barroisite overgrowths on the rims of glaucophane and by the presence of barroisite-albite symplectites on the rims of omphacite; ( $f$ ) Retrogression is more pronounced in eclogite GR 24a: rutile is totally replaced by titanite, barroisite-albite symplectites along omphacite are well developed and garnet is partially altered in chlorite + iron hydroxides. Quartz veins parallel to the main schistosity are also present. Mineral abbreviations are from Kretz (1983). "Sympl" = Albite and barroisite symplectites. 

2 4 5 6

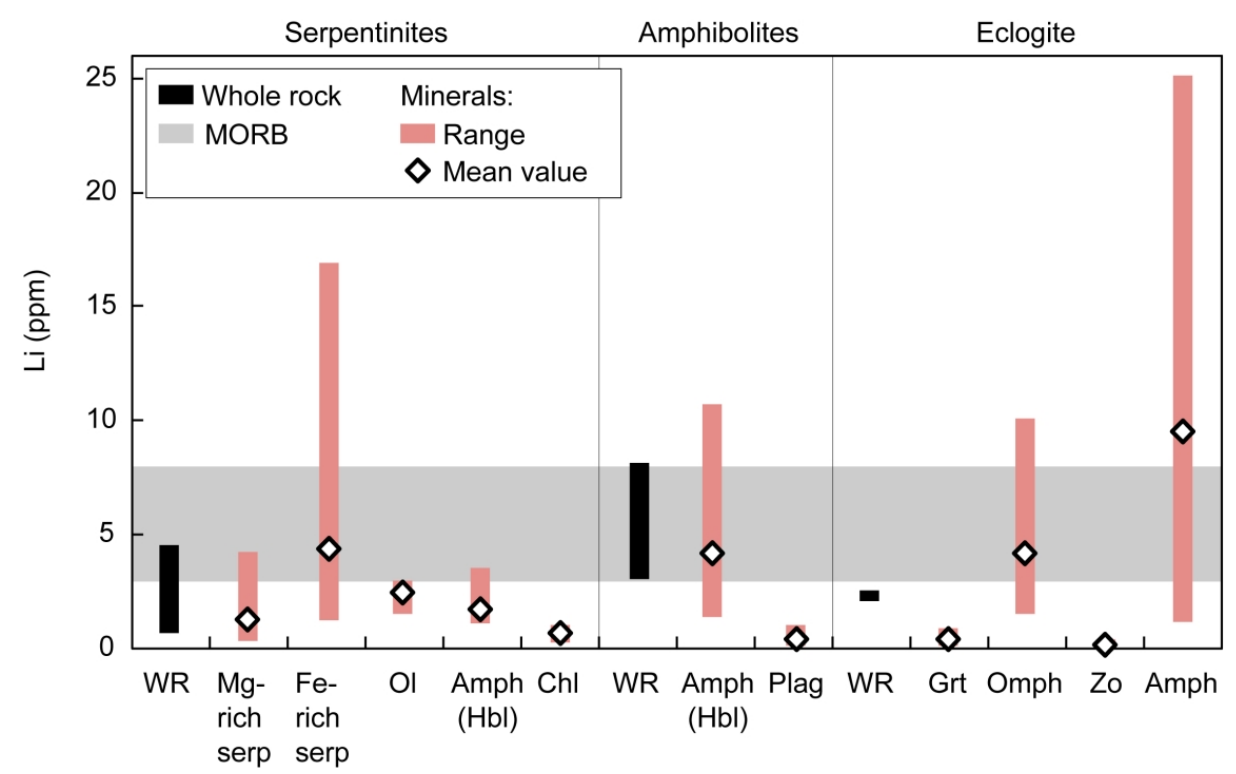

Figure 3. Variation in Li abundances in whole rocks and minerals from the Limousin ophiolite. The Li composition of fresh MORB is from Ryan \& Langmuir (1987) and Niu \& Batiza (1997). WR: whole rock 
(a) Serpentinites

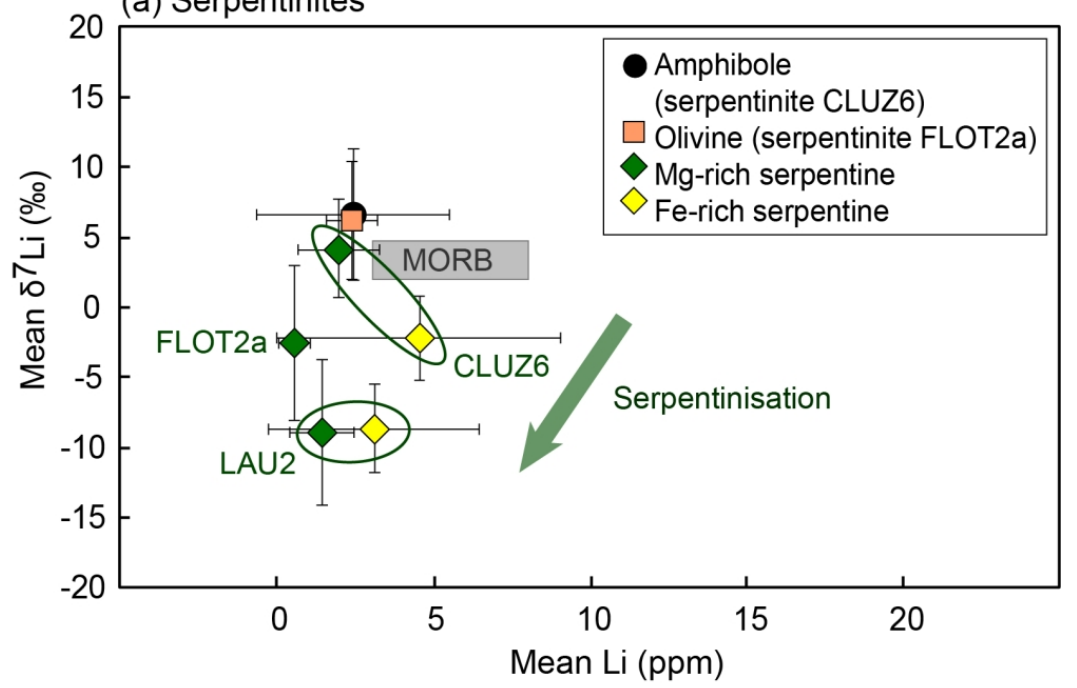

(b) Amphibolites and UHP eclogite

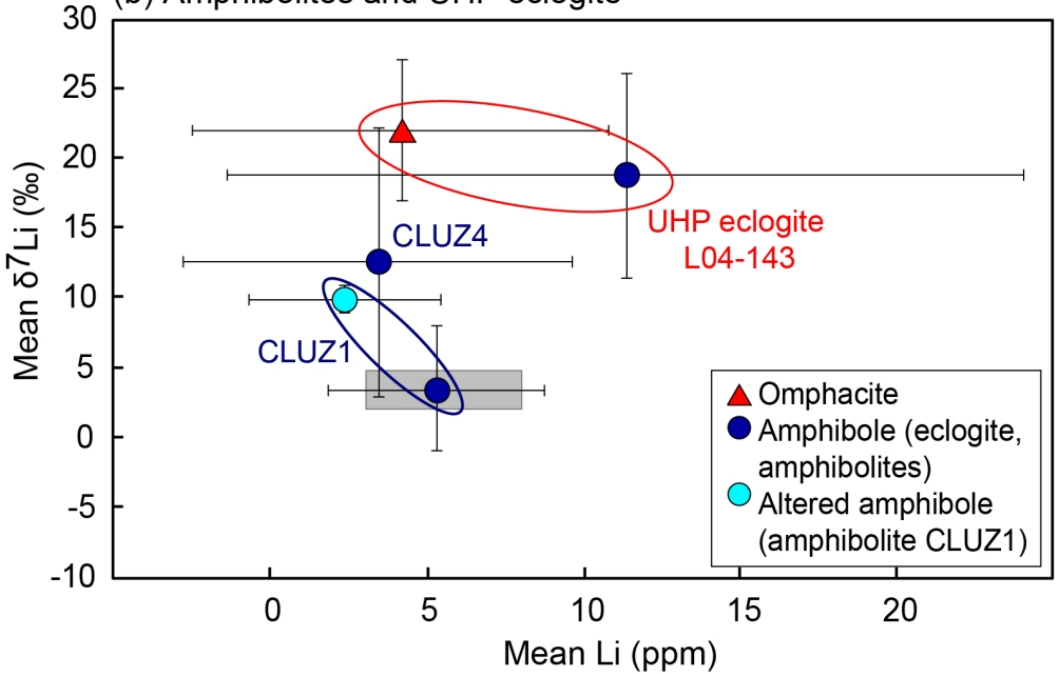

Figure 4. Variation of the mean $\delta^{7} \mathrm{Li}$ values relative to $\mathrm{Li}$ abundances in the minerals from the rocks of the Limousin ophiolite. Amphibole in serpentinites and amphibolites is mainly tremolite and hornblende, while amphibole in the UHP eclogite L04-143 is pargasite. Error bars are $2 \sigma$ SD. The Li elemental composition of fresh MORB is from Ryan \& Langmuir (1987) and Niu \& Batiza (1997). The Li isotopic composition is from Chan et al. (2002), Bouman et al. (2004) and Tomascak et al. (2008). 

2 3 4 5 6 7 8 9 10

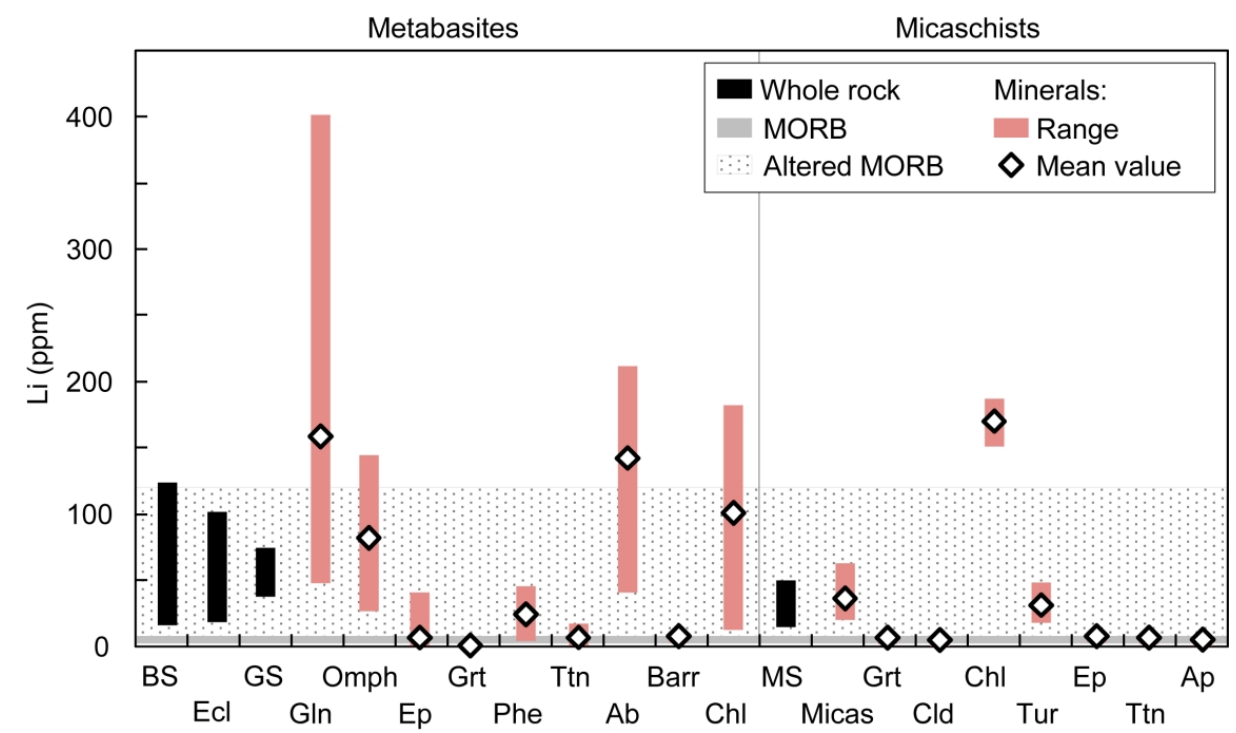

Figure 5. Variation in Li abundances in whole rocks and minerals from the Ile de Groix HP terrane. The Li composition of fresh MORB is from Ryan \& Langmuir (1987) and Niu \& Batiza (1997). The Li composition of altered MORB is from Chan et al. (2002), Bouman et al., (2004) and Coogan et al. (2017). BS: blueschists; Ecl: eclogites; GS: greenschists; MS: micaschists; Micas: phengite + paragonite 

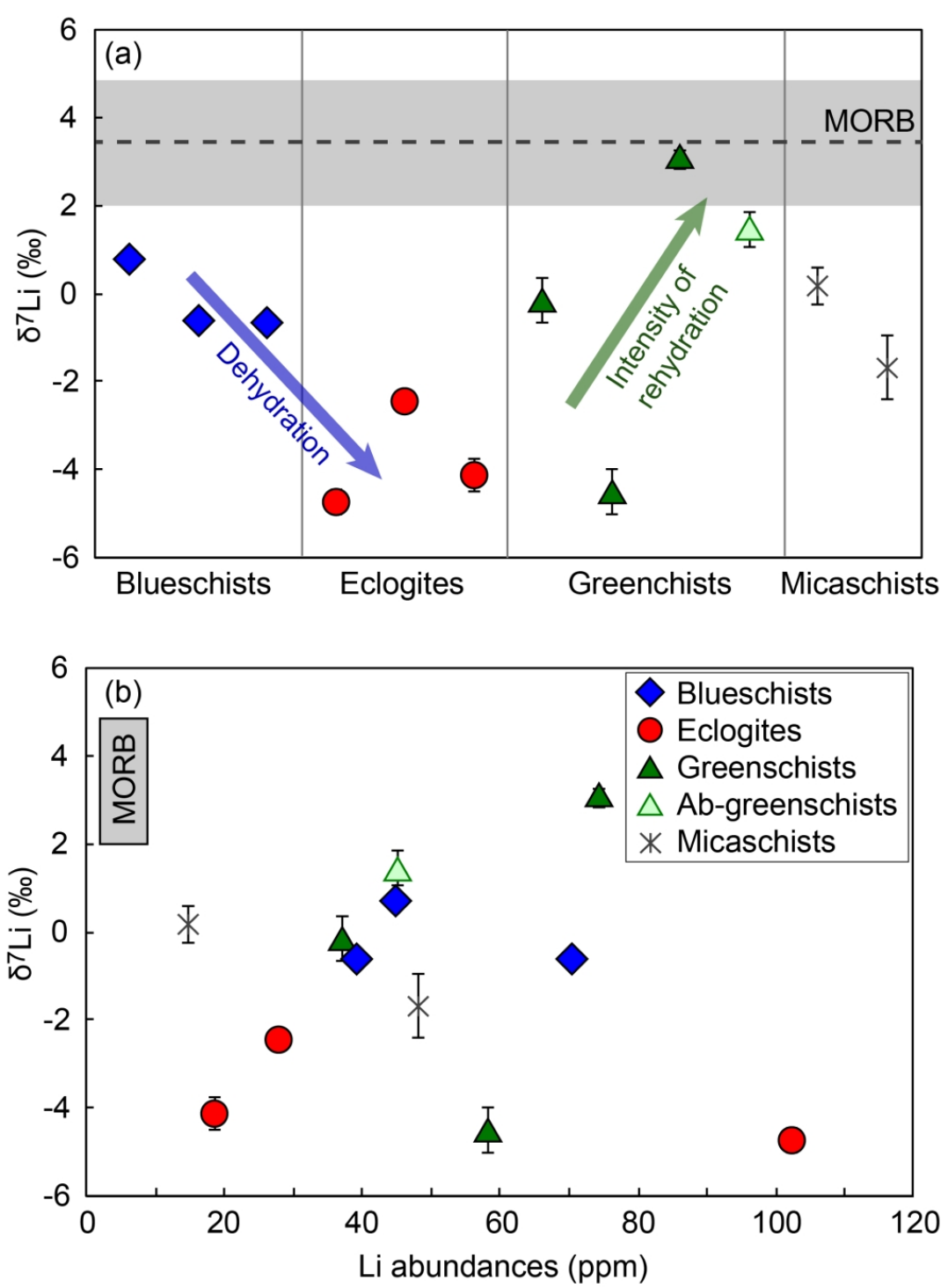

Figure 6. (a) Li isotopic composition of the metabasites and micaschists of the Ile de Groix. The $\delta^{7} \mathrm{Li}$ values decrease from the blueschist facies to the eclogite facies. During retrogression, the $\delta^{7} \mathrm{Li}$ values increase with the intensity of rehydration. (b) $\delta^{7} \mathrm{Li}$ values vs. Li abundances. No correlation is observed with the variation of the metamorphic facies. Error bars for $\delta^{7} \mathrm{Li}$ values are $2 \sigma \mathrm{SE}$, as the whole rock $\delta^{7} \mathrm{Li}$ is calculated by averaging replicate analyses of the same sample solution. 

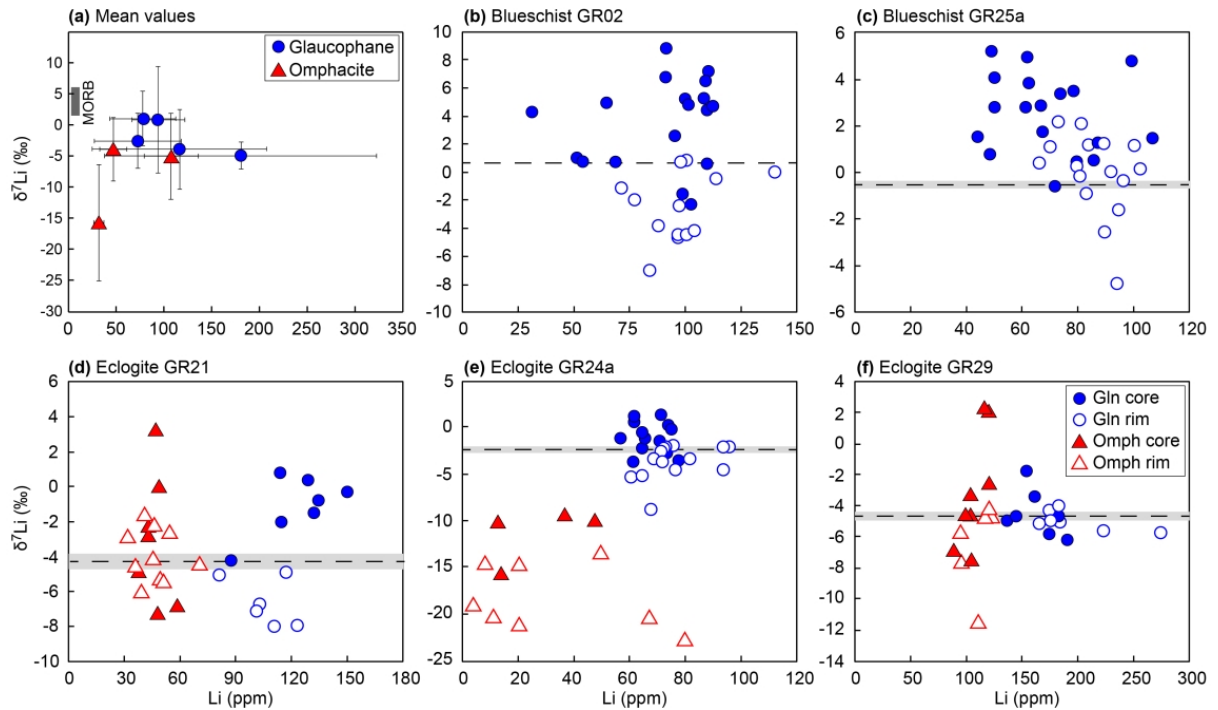

Figure 7. Variations in Li content and isotopic composition of glaucophane and omphacite from the metabasites of the Ile de Groix. (a) Mean $\delta^{7} \mathrm{Li}$ vs. Lithium contents. Mean Li abundances were calculated using the LA-ICPMS data. Mean $\delta^{7} \mathrm{Li}$ values correspond to unweighted average of all in-situ $\delta^{7} \mathrm{Li}$ values measured by SIMS in each sample. Error bars are $2 \sigma$ SD. The dark grey field represents the Li composition of fresh MORB (Ryan \& Langmuir, 1987; Niu \& Batiza, 1997; Chan et al., 2002; Bouman et al., 2004; Tomascak et al., 2008) (b-f) Core-to-rim variations of the $\delta^{7} \mathrm{Li}$ values and Li contents in (b-c) blueschists and, (d-f) eclogites. The dotted lines and grey field give the corresponding whole rock and $2 \sigma$ SE values. Individual $\mathrm{Li}$ abundances were calculated based on the mean $\mathrm{Li}$ contents obtained by LA-ICPMS and ${ }^{6+7} \mathrm{Li}$ intensities, as follows: $\mathrm{C}(\mathrm{Li})_{i}{ }^{\text {SIMS }}=\left[\mathrm{I}(\mathrm{Li})_{i}{ }^{\text {SIMS }} \times \mathrm{C}(\mathrm{Li})_{\text {mean }}{ }^{\text {LA-ICPMS }}\right] / \mathrm{C}(\mathrm{Li})_{\text {mean }}$ SIMS 
(a) Limousin

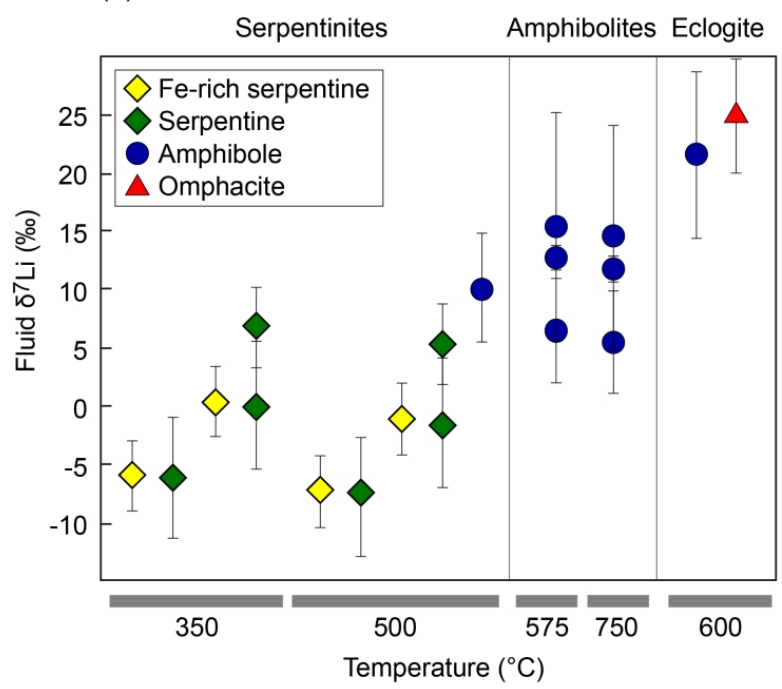

(b) lle de Groix

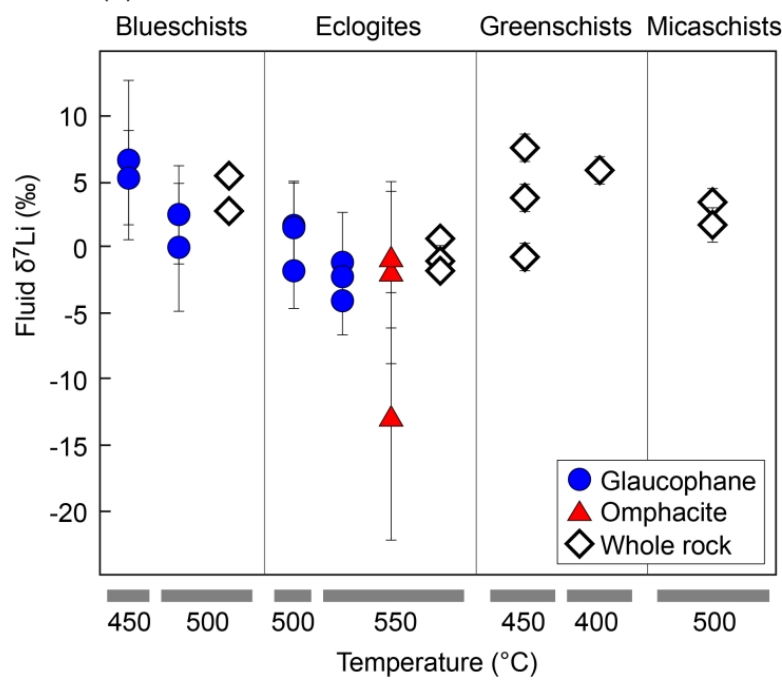

Figure 8. Calculated $\mathrm{Li}$ isotope composition of fluids in equilibrium with rocks and minerals in the rocks from: (a) the Limousin ophiolite and, (b) the Ile de Groix. $\delta^{7} \mathrm{Li}_{\text {fluid }}$ calculations were made using the clinopyroxenefluid fractionation factors for amphiboles, omphacite and whole rocks, and the mica-fluid fractionation factor for serpentine (Wunder et al., 2006, 2011): $\delta^{7} \mathrm{Li}_{\text {fluid }}=\delta^{7} \mathrm{Li}_{\text {sample }}-\Delta^{7} \mathrm{Li}_{\text {mineral-fluid. }}$ The $2 \sigma$ uncertainties, represented by the error bars, are identical to those of the mean $\delta^{7} \mathrm{Li}$ of minerals and whole rocks employed for calculation. (a) The $\delta^{7} \mathrm{Li}$ values of the fluids in equilibrium with serpentine were calculated for $350^{\circ} \mathrm{C}$ and $500^{\circ} \mathrm{C}$, as the temperature of hydrothermal alteration is not precisely constrained. (b) It is assumed that glaucophane rims have formed at a temperature $50^{\circ} \mathrm{C}$ higher than glaucophane core. 